University of Michigan Law School

University of Michigan Law School Scholarship Repository

1971

\title{
Direct Judicial Review and the Doctrine of Ripeness in Administrative Law
}

Joseph Vining

University of Michigan Law School, jvining@umich.edu

Available at: https://repository.law.umich.edu/articles/1638

Follow this and additional works at: https://repository.law.umich.edu/articles

Part of the Administrative Law Commons, Courts Commons, and the Legislation Commons

\section{Recommended Citation}

Vining, Joseph. "Direct Judicial Review and the Doctrine of Ripeness in Administrative Law." Mich. L. Rev. 69 (1971): 1443-546.

This Article is brought to you for free and open access by the Faculty Scholarship at University of Michigan Law School Scholarship Repository. It has been accepted for inclusion in Articles by an authorized administrator of University of Michigan Law School Scholarship Repository. For more information, please contact mlaw.repository@umich.edu. 


\title{
Direct Judicial Review and the Doctrine of Ripeness in Administrative Law
}

\author{
G. Joseph Vining
}

Table of Contents

I. INTRODUCTION . . . . . . . . . . . . . 1445

II. The Problem of Direct Review . . . . . . . 1446

III. The Place of Direct Review in the Administrative

Procedure ACT . . . . . . . . . . . . . 1452

A. Section 10 . . . . . . . . . . . . . . 1452

B. Administrative Declaratory Orders: Section 5(d) 1458

IV. The Response of the Courts to Demands for Direct REVIEW . . . . . . . . . . . . . . . . 1463
A. Expansion of the Terms "Order" and "Proceed- ing" in Special Statutory Review Provisions . . 1463
B. Contraction of Equity Prerequisites . . . . . 1465
C. Control of Discretion and Inaction . . . . . . 1467
D. The Divorce of Standing and Sanctions . . . . 1469
E. The Consolidation of Doctrine in Light of the Public Function of Judicial Review . . . . 1473

V. Standing and the Right to Direct Judicial Review of Final Agency Action . . . . . . . . . . 1476
A. Linking the Litigant to the Regulatory System 1476
B. The Presumption of Judicial Review . . . . . 1483
C. The Divorce of Remedy and Review . . . . . 1487
D. The Residual Doubt . . . . . . . . . . 1490 
VI. The Problem of Abbott Laboratories v. Gardner 1491

A. Abbott and the Consolidation of Review within the APA . . . . . . . . . . . . . . . 1492

B. Abbott and the Presumption of Direct Judicial Review . . . . . . . . . . . . . 1493

G. The Anomaly of Ripeness . . . . . . . . 1495

VII. Administration of the Ripeness Doctrine: Judicial Ghotce Between Direct and Enforcement Review 1501

A. Defects in the Calculation of Costs . . . . . 1501

1. "Hardship to the Parties" . . . . . . . 1502

2. The Dark Side of the Administrative Process 1505

3. The Effect of Delay Upon the Agency . . . 1508

4. Choice of Litigation by Individuals . . . . 1511

5. Ghoice Among Individual Litigants . . . . 1512

6. Civil Disobedience . . . . . . . . . . 1514

B. Defects in the Calculation of Gains . . . . . . 1514

1. Finality . . . . . . . . . . . 1515

2. Illumination of the Issues . . . . . . . 1516

VIII. The Appearance of Choice: The Ripeness Decision as a Judgment on the Merits . . . . . . . . 1522

A. Categorization of a Rule . . . . . . . . . 1522

B. The Problem of the Hypothetical Case . . . . 1529

IX. Further Consequences of Jurisdictional Litigation 1531

A. Prejudging the Merits . . . . . . . . . . 1531

B. Interference in the Legislative Process . . . . 1536

C. Uncertainty . . . . . . . . . . . 1538

X. Judicial Review Without the Doctrine of Ripeness 1539

XI. Conclusion . . . . . . . . . . . . . 1544 


\title{
DIRECT JUDICIAL REVIEW AND THE DOCTRINE OF RIPENESS IN ADMINISTRATIVE LAW
}

\author{
G. Joseph Vining* \\ I. INTRODUGTION
}

$\mathrm{T}$

HUERE has been recent interest in rationalizing and codifying the opportunities for judicial review of federal administrative determinations outside an enforcement context or special proceedings designated by statute. Abbott Laboratories $v$. Gardner ${ }^{1}$ culminated the development of a strong judicial presumption in favor of such review, founded in general considerations and justified by the broad language of the Administrative Procedure Act (APA or Act). ${ }^{2}$ Since the petitioners in Abbott had theoretical rights to later review of the agency position in enforcement proceedings, the Court called the procedure "pre-enforcement" review. But similar opportunities for immediate and direct review of agency positions at the instance of affected persons not ultimately subject to licensing or sanctions have been developed under the rubric of "standing," and the Court recently brought the two strands together in Association of Data Processing Service Organizations, Incorporated v. Camp. ${ }^{3}$ Arguably, a comprehensive right to judicial review of an agency position as such is now recognized, except when there is clear evidence of congressional intent to preclude such review. "Pre-enforcement review" is an unsuitable term to describe what has emerged, as is "non-statutory review" since the rights recognized are grounded in the APA. And since, as we shall see, timing is not alone at stake, "immediate review" will not do either. We shall use "direct review" here as a generic substitute. ${ }^{4}$

- Assistant Professor of Law, University of Michigan. B.A. 1959, Yale University; M.A. 1961, Cambridge University; J.D. 1964, Harvard University.-Ed.

This paper is an outgrowth of work undertaken as a consultant to the Committee on Judicial Review of the Administrative Conference of the United States. Neither the Conference nor the Committee has evaluated or approved this paper. I am, however, indebted to my colleague and the current Chairman of the Conference, Roger C. Cramton, for his criticism and encouragement.

1. 387 U.S. 136 (1967). For a discussion of the case, see pt. VI. infra.

2. Act of June 11, 1946, ch. 324,60 Stat. 237, as amended, 5 U.S.C. $\$ \S 500,551-59$, 701-06 (Supp. V, 1965-1969) [hereinafter APA].

3. 397 U.S. 150 (1970).

4. Cf. ICC v. Atlantic Coast Line R.R., 383 U.S. 576 (1966). "Direct review" is also a shorthand reference to initiation of the review proceeding in a court of appeals rather than a district court. We are not concerned with questions of venue, but the connotations that may be carried over to the use of the term here will not be out of 
The doctrine of "ripeness," which was also given definitive form in Abbott, and the judicial discretion to withhold review that it authorizes, is central to any consideration of direct review. It is a troubling anomaly. The arguments for or against its retention in administrative procedure are virtually the same as those which can be made for or against direct review itself. And so long as the doctrine is retained, the advantage of any codification of rights to direct review may be outweighed by the uncertainties that are inevitably created by any venture into basic statutory change. Since $A b b o t t$, the Court may have come very close to eliminating "ripeness" as an independent test for the appropriateness of judicial review in given circumstances; but it has not done so explicitly, and the doctrine remains very much alive and at large in the thinking of lower federal courts and, indeed, in administrative law generally. We propose therefore to examine the status of the doctrine in detail, and to suggest what might be gained if it were abandoned.

\section{The Problem of Direct Review}

Whenever an agency administering a comprehensive regulatory scheme adopts an authoritative position on a question, the plans of persons and groups active in the regulatory field are affected. Indeed, they are affected whenever the agency acts to crystallize a question for authoritative resolution out of the flux of problems being handled by those in the field. Plans must change, and this does not mean change merely in expectations and paper calculations, in hopes and fears. Purchasing and personnel training programs, research and product design, financial arrangements, even organizational structures must be redirected to a greater or lesser degree to accommodate or avoid the new fixed point.

In some cases affected individuals are indifferent to the way a question is formulated or resolved, at least insofar as they act together through corporate institutions. ${ }^{5}$ Certainty is the primary concern, and the administrative position, perhaps reflecting a lengthy phase of negotiation and adjustment, passes into the structure of things unchallenged. But often the effects of the agency position are

place. Many of the considerations that favor review of the kind we treat here, such as the possibility of disentangling remedial and substantive questions or of avoiding broad judicial discretion to deny review, have led legislative draftsmen and litigants to favor review proceedings in courts of appeal. See, e.g., Medical Comm. for Human Rights v. SEG, 432 F.2d 659, 663 (D.C. Cir. 1970), cert. granted, 401 U.S. 973 (1971).

5. For an inquiry into the problem of distinguishing legally between institutional and individual interests, see note 236 infra. 
not viewed as neutral or benign, and the costs of necessary changes in policy and program and the projected impact of those changes on the achievement of individual and institutional goals make challenge worthwhile. Or the appearance of the position may be seen as simply increasing the uncertainty of affairs. The result is a search by an individual or enterprise or by the affected group as a whole for some form of judicial review.

Agency positions are communicated to the field in a number of ways. They may be announced in "rules required by statute to be made on the record after opportunity for an agency hearing," to which section 4(b) of the APA makes reference. ${ }^{8}$ The hearing is upon issues framed by objections to a proposed rule, and this together with the requirement that the final agency decision be made "on the record" makes the administrative proceeding a highly adversary trial of the rule itself." But such "adjudicatory rule-making" is rare. Rules formally promulgated under organic ${ }^{8}$ statutory provisions for specific rule-making, which do not require full hearing and decision on a record, and which are therefore often developed under the procedures of section 4 of the APA, ${ }^{9}$ have a far greater sweep and importance. Rule 10b-5 of the Securities and Exchange Commission (SEC) ${ }^{10}$ is a prime example. "Interpretive rules," which set forth the administrative extrapolation of statutory norms that speak directly to regulated parties, and which are intended to guide agency personnel in their enforcement activity and private parties (or other agencies) in their planning, differ from such "legislative" rules only in the more general statutory authority for their promulgation ${ }^{11}$ and the

6. 5 U.S.G. § 553(c) (Supp. V, 1965-1969).

7. See Pharmaceutical Mfrs. Assn. v. Gardner, 381 F.2d 271 (D.C. Cir. 1967); 21 U.S.C. \& 371(c) (1964) (food, drug, and cosmetic regulations issued by Food and Drug Administration [hereinafter FDA]); 15 U.S.C. § 1455(a) (Supp. V, 1965-1969) (fair packaging regulations issued by Federal Trade Commission [hereinafter FTC]).

8. By "organic" we mean a statute or statutory system that pertains specifically to a particular agency or a particular substantive field of regulation and that embodies the legislated values governing the field. See United States v. Morton Salt Co., 338 U.S. 632,648 (1958).

9. 5 U.S.C. $\& 553$ (Supp. V, 1965-1969).

10. 17 C.F.R. \& 240.10b-5 (1971).

11. The Federal Power Commission [hereinafter FPC] is authorized to "prescribe, issue, make, amend and rescind such orders, rules and regulations as it may find necessary or appropriate to carry out the provision of this chapter" (16 U.S.C. \$ 825(h) (1964)); the FDA to "promulgate regulations for the efficient enforcement of this chapter" (21 U.S.C. § 371(a) (1964)); the Securities and Exchange Commission [hereinafter SEC] "to make such rules and regulations as may be necessary for the execution of the functions vested in them by this chapter" (15 U.S.G. $\S 78$ w(a) (1964)); the FTC to make rules "necessary and proper for administration and enforcement" of the Wool Products Labeling Act (I5 U.S.C. § 68d(a) (1964)). 
degree of deference accorded them by courts when they are challenged. They have much the same kind of content and much the same effect. Then there is evidence of the adoption of institutional positions which appears without the indicia of "rule-making"--in the letters, press releases, statements of policy, and consistent patterns of advice followed by careful lawyers and often collected and systematized by specialized private reporting services. There is no specific statutory authority for these methods of communication, any more than there is statutory authority for speech-making by administrative offcials. Authority is "implied" or "inherent." But while speeches indicate only pressure or movement toward an agency position, many of these other communications reveal a position that is meant to guide and that, until changed, will control the action of the administrative organism. They have a function and effect virtually indistinguishable from announcements in the form of "rules." 12 Finally, there are positions that assume institutional form for the first time during an adjudication or an enforcement proceeding-in a standard set of charges or a pattern of prosecutions, in rulings issued before the "end" of the administrative phase of the "case," in carefully calculated dicta in agency opinions, or in briefs, motions, and responses filed by the agency in court. Once announced, the position begins to affect officials, persons, and groups active in the regulated field in ways little different from the promulgation of rules, both because administrative agencies are judicially held to some standard of consistency and because in practice institutional positions are not lightly taken or easily changed. ${ }^{13}$

12. This has long been recognized. In Columbia Broadcasting Sys., Inc. v. United States, 316 U.S. 407, 415 (1942), the Court held that the order of the Federal Communications Commission [hereinafter FCC] promulgating chain broadcasting regulations was an "order" reviewable under the Urgent Deficiencies Act. Chief Justice Stone observed that the fact the word order appeared in the FCC's announcement of its position was immaterial: "The particular label placed upon it by the Commission is not necessarily conclusive, for it is the substance of what the Commission has purported to do and has done which is decisive." 316 U.S. at 416. Justice Frankfurter, dissenting, went on to note that

Announcements of general policies intended to be followed by administrative agencies customarily take any one of various forms. Sometimes they are noted in the agency's annual report to Congress, sometimes in a public announcement or press release, and sometimes, as was the case here, they are published as "rules" or "regulations." See Final Report of the Attorney General's Committee on Administrative Procedure (1941), pp. 26-27. But whatever form such announcements may take, their nature and effect is the same.

316 U.S. at 431. Cf. Barr v. Mateo, 360 U.S. 564, 574-75, 578 (1959).

13. See, e.g., SEC v. Chenery Corp., 318 U.S. 80 (1943), 332 U.S. 194 (1947); Columbia Broadcasting Sys., Inc. v. United States, 316 U.S. 407, 421 (1942) ("Of course, the Commission was at liberty to follow a wholly different procedure. Instead of proclaiming general regulations applicable to all licenses, in advance of any specific contest over a license, it might have awaited such a contest to declare that the policy which these regulations embody represents the concept of the public interest.") 
Only in the event that a position is announced in the course of "adjudicatory rule-making," however, can an affected party obtain review of its legality without first persuading a court that there is a need to look at the merits or meeting serious questions about the timing, form, and effect of the review proceeding. There are no "special statutory review" procedures, which would obviate such questions, attached to the authorizations in organic statutes for the announcement of positions in the form of "legislative" or "interpretive" rules, ${ }^{14}$ and no place in the organic statutes for the attachment of such procedures to the announcement of positions in other ways. Review has always been granted as a matter of course when a party is involved in a "case" and disposition of the legal issue is necessary to the disposition of the "case." This is "enforcement review," and it occurs regularly when an authorized private party or agency officials rely upon the position in seeking to hold a chosen respondent for violating a directly applicable statutory norm,,$^{15}$ an agency order or a rule expressly given statutory force, ${ }^{16}$ or for acting without a license that is arguably required by statute. "Enforcement review" is also granted when resolution of the legal challenge is necessary to dispose of an objection to a sanction or to a denial of a benefit or a license that an agency has ordered after an administrative adjudication in which the challenged position has figured. But those who are not involved in such a "case" face a bout of preliminary litigation in which they must show that the court has "jurisdiction"-whether they be the objects of regulation who are ultimately subject to direct sanctions, the beneficiaries of regulation who are indirectly constrained by what directly regulated entities are permitted to do, or parties to a "case" who wish to step outside its confines to obtain a more certain, more focused, or accelerated resolution of an issue.17

14. An organic statute may, however, explicitly incorporate the APA (see Motor Vehicle Safety Act § 105(a)(3), 15 U.S.C. § 1394(a)(3) (Supp. V, 1965-1969)) or include general provision for review of agency "orders" (see pt. IV. A. infra).

15. See, e.g., United States v. 1500 Cases, More or Less, Tomato Paste, 236 F.2d 208 (7th Cir. 1956).

16. See, e.g., SEC v. Transamerica Corp., 163 F.2d 531 (3d Cir. 1947), cert. denied, 392 U.S. 847 (1948); Wool Products Labeling Act § 3(a), 15 U.S.C. \& 68(a) (1964).

17. For a striking example of an agency position that emerged in papers filed in the preliminary proceedings of a litigation, and that was found directly reviewable on the petition of affected persons not party to the litigation, see Dellinger $v$. Mitchell, 39 U.S.L.W. 2487 (D.C. Cir. Feb, 16, 1971) (Leventhal, J.). The Department of Justice asserted the legality of electronic surveillance of domestic organizations without judicial warrant during discovery proceedings in the "Chicago Conspiracy Trial," and nine organizations (as well as the defendants) sought declaratory and injunctive relief in the District Court for the District of Columbia Circuit. The opinion contains an illuminating discussion and review of the problems and policies appropriate to a de- 
They all seek "pre-enforcement" or direct review of the legality of a position that affects them in their planning, and the history of their defeats and triumphs in persuading courts to look at the merits fills the pages of administrative law.

That direct review of agency positions should have been beset with special questions about timing, form, and parties is attributable in large measure to the conceptual framework for the resolution of legal issues that administrative law inherited from the era of private law. In that model courts sat to choose between private parties fighting over real things. Even when a situation for which government was clearly responsible was put in question, the suit ran against an official as an individual. ${ }^{18}$ When courts "intervened" they disposed of "cases," not legal issues.19 A "case" was a product more of natural evolution than of design, and, when finally formed through a series of preliminary proceedings, it limited and organized thought, took on a life and timing of its own, and ended with relief or a sanction that was assumed to be the primary concern of the contending parties. There was no place for the determination of legal rules as such. "Cases" were complete and discrete units, unrelated to one another except in linear fashion through the doctrine of stare decisis. In the name of individual freedom as well as judicial economy, courts refused to go beyond what the "case" required, and in any event "law" was by definition no more than a dynamic tension between concrete decision and immanent generality.

But the traditional concept of the "case" does not reflect the realities of the administrative process, and fits most uneasily into administrative law. ${ }^{20}$ With the growth of institutions on all sides, the

cision whether to break a question out of an existing case. See also text accompanying notes 340-41 infra.

18. See A. Dicex, Introduction to the Study of the LAw of the Constrtution 193-94, 202-03 (9th ed. 1939); Cramton, Nonstatutory Review of Federal Administrative Action: The Need for Statutory Reform of Sovereign Immunity, Subject Matter Jurisdiction, and Parties Defendant, 68 MrCH. L. REv. 387, 398.99 (1970). Cf. Corbin, Legal Analysis and Terminology, 29 YALE L.J. 163, 165 (1919).

19. Cf. Collins v. Miller, 252 U.S. 364 (1920) (Brandeis, J.) (habeas corpus appeal dismissed sua sponte by court for want of jurisdiction):

The fundamental question whether the judgment appealed from is a final one ...

has suggested itself to the court ....

A case may not be brought here by appeal or writ of error in fragments. To be appealable the judgment must be not only final, but complete. ... Only one branch of the case has been finally disposed of below, therefore none of it is ripe for review by this court.

252 U.S. at $365,370-71$.

20. Cf. the discussion of judicial stays pending completion of related administrative proceedings and the problems of confining a reviewing court's exclusive jurisdiction to the "case" before it by Jaffe \& Vining, Temporary Judicial Stays of Administrative 
character of the legal persons that appear before courts has changed. Courts no longer speak primarily to individuals but to engines constructed for the pursuit of chosen public values. Common-law jurisprudence simply did not contemplate contending parties which themselves initiate policy and view the instance as subordinate to the larger whole, and which are moved as much by rules as by "real" interests. Too frequently now the sanction is not the primary object of concern; it is instead the governing rule that will emerge from the litigation. The timing of the resolution of particular issues crystallized at the outset or in the course of argument therefore need not be determined primarily by its impact on the progress of the "case" toward the ultimate remedy, but rather by its impact upon the administrative program and the planning of those active in the regulatory field.

Moreover, the distribution among discrete cases of issues of general importance that crystallize out of the flux of the administrative process is often arbitrary. At any given time the agency and the parties in an administrative "case" may have related interests in the issues being considered in a number of other "cases," the disposition of which will have as much importance to the need for the challenge and the nature of the arguments in the case at hand as any issue being considered within its confines. Indeed, the consequences of arguments for the outcome of another "case," rather than their relative strength in achieving the immediate goal, may determine their use in the case at hand. ${ }^{21}$ The result is a distortion of the classical theory of the "case" as a building block of substantive law-a cell in which adversaries can be expected to develop all the relevant arguments in their strongest form for a limited and comprehensible purpose. Such distortion is present to some extent in all litigation by institutions. It

Action Pending Judicial Review, and Exclusive Jurisdiction and Remand, in L. JAFFE, Judicial Control of Admisistrative Action 699-700, 715-17 (1965).

21. An example is Montana Power Co. v. FPC, 38 U.S.L.W. 2050 (D.C. Cir., June 26, 1969), vacated on rehearing, UTIL. L. REP. I 11,141, at 12,357 (D.C. Cir. 1970), cert. denied, 400 U.S. 1013 (197I), a proceeding to set rentals for Indian lands underlying a dam and power plant. Also underway was a separate rule-making proceeding, in which the utility was actively participating, to establish accounting practices and valuation standards for recapture of all federally licensed hydroelectric facilities at the expiration of the license terms. See FPC Order No. 370, Sept. 27, 1968. Of obviously greater concern to the utility than the dollar rental figure that might emerge from the adjudication was the possibility of making a concession in its briefs or formulating an issue in such a way that a premise might be judicially approved that would prejudice the outcome of the rule-making proceeding. Cf. Petitioners' Reply Brief at 15-16. The utility could not, for instance, argue against the rationality of an accounting method in the recapture proceedings and accept it in the rental calculation proceedings, whatever its dollar advantage over the alternative methods of rental calculation available and in dispute. 
is endemic, however, in much of the administrative process where the same parties face each other continually in proceedings that are tied together by the ultimate regulatory goals, and where consistency from "case" to "case" comes to be required as much from the "private" party as from the agency or the courts.

Thus a nod to common-law tradition is not enough to answer those who seek to resolve questions regarding the operating rules as they emerge from the modern administrative process. ${ }^{22}$ As the scope of overt regulation has expanded and the impact of agency positions has been more and more widely felt, the pressure upon the legal system to make a place for direct review has increased. We are now at a point where one may ask whether courts, when presented with a legal challenge to an agency position, are authorized to abandon a search for a case as traditionally conceived and simply create a "case" around the issue itself.

\section{The Place of Direct Review in the Administrattve Procedure Act}

\section{A. Section 10}

If one tracks through the APA for its response to these questions and needs, one emerges with a handful of ambiguities. The Revised Model State Administrative Procedure $\mathrm{Act}^{23}$ and a number of state statutes make general provision for judicial review of agency positions through declaratory judgments, with or without prior administrative proceedings to remove uncertainties in scope or meaning. ${ }^{24}$ The APA does not, and the draftsmen of the new state provisions have apparently assumed that they were going beyond at least the explicit federal statutory guarantees in embracing the "principle [of] advance determination of the validity of administrative rules, and [of] 'declaratory rulings,' affording advance determination of the applicability of administrative rules to particular cases." ${ }^{25}$

22. The loosened grip of the common-law model is reflected in the Court's provocative use of Muskrat v. United States, 219 U.S. 346 (1911), as an example of thinking that now has "the hollow ring of another era." Port of Boston Marine Terminal Assn. v. Rederiaktiebolaget Transatlantic, 400 U.S. 62, 71 \& $\mathrm{n} .20$ (1970). The court was rejecting an argument that agency action was not a final agency order because it had no "independent coercive effect."

23. 9C ULA (Supp. 1967) [hereinafter Revised Model Act].

24. See Revised Model Act $\S \S 7-8$, in 9C ULA (Supp. 1967). At least twenty states have adopted provisions patterned after the Model State Administrative Procedure ACT $\$$ 6-7, in 9C ULA (1957), or the Revised Model Act providing for agency and/or judicial declaratory judgments. E.g., MICF. STAT. ANN. $\$ \$ 3.560(7)-(18),(21.1)-(21.10)$ (1969); GA. Code ANN. §§ 3A-111, -112 (Supp. 1970); Wis. STAT. ANN. §§ 227.05-.06 (1957). 25. See Commissioners' Prefatory Note to Revised Model Act, 9C ULA at 141 (Supp. 
Section 10(a) of the APA ${ }^{26}$ with its guarantee of a right of review does not speak to cases ready-made. It speaks to the reviewability of agency "actions," which are thereafter conceptually grouped into "cases" or "proceedings." Agency "action," as defined in section $2(\mathrm{~g}),{ }^{27}$ includes both "rules" and the results of "adjudications," as well as failures to adjudicate or issue a rule. A "rule" is defined in 2 (c) in the broadest terms and can include all instances of what we have described above as the adoption of institutional positions-an "agency statement . . . designed to implement, interpret, or prescribe law or policy." 28 Under the first sentence of section 10(c), however, such action is "reviewable" only if it is "final" and if "there is no other adequate remedy in a court," unless it is made "reviewable" by statute. ${ }^{29}$

"Adequacy" and "finality" are undefined. Both conditions may govern whether an action may be reviewed as an independent matter, that is, whether a new and separate case can be formed for the resolution of challenges to it. A search for some "other adequate remedy" is a search for another "case," existing or contemplated. "Finality" speaks to the timing of review, but not just in the sense that the position must have crystallized before a case can be formed around it. ${ }^{30}$ There is a suggestion that some actions should not in any event be broken out of the "case" in which they appear, in the near tautology in the second sentence of section 10(c) that "preliminary, procedural or intermediate" actions and "ruling[s] not directly reviewable" are to be reviewed in connection with the "final," reviewable action. ${ }^{31}$ The judicial determination that an "action" or "ruling" is "not directly reviewable," and that it is "preliminary" or "intermediate" to some other action or that it is "procedural," would

1967); Commissioners' Notes to Revised Model Act §§ 7-8 in 9C ULA at 150 (Supp. 1967). In view of the usual limitation of such review under state law to cases where "legal rights" are threatened (see Revised Model Act § 7, 9G ULA (Supp. 1967)), federal rights to direct review now recognized as implicit in the APA may in fact be broader. See text accompanying notes 133-41 infra. But this development in state law has been thought additional reason to reconsider the parallel problems in federal administrative procedure.

Some question may be raised about the desirability (and practicality) of impairing the power of agencies in the federal system to avoid taking positions and maintain useful ambiguities through creation of a statutory right to "declaratory rulings [by the agency] as to the applicability of any statutory provision like that in $\S 8$ of the Revised Model Act.

26. 5 U.S.C. $\$ 702$ (Supp. V, 1965-1969).

27. 5 U.S.C. \& 551(12)-(13) (Supp. V, 1965-1969).

28. 5 U.S.C. $\$ 551(4)$ (Supp. V, 1965-1969) (emphasis added).

29. 5 U.S.C. $\$ 704$ (Supp. V, 1965-1969) (emphasis added).

30. See note 216 infra and accompanying text.

31. 5 U.S.C. § 704 (Supp. V, 1965-1969) (emphasis added). 
necessarily be a determination that the logic of an existing case should determine the timing and substantive priority of its review. ${ }^{32}$

Let us pause a moment over this pivotal term "final." Its apparent change of meaning even within the same statutory section should not be surprising. The one term is made to serve a number of functions in statutes and legal discourse. It can summon up policies in favor of repose. ${ }^{33} \mathrm{We}$ suggest below that the possibility of repose is not and should not be a prerequisite or a necessary outcome of review in modern administrative law, although repose may generally be the motivation to seek review. "Final" can also say something about the agency's institutional processes and measure the need to avoid judicial examination of what is only tentative and inchoate, and without institutional force. That may be its function in the first sentence of section $10(\mathrm{c}) \cdot{ }^{35}$ And the term can express the quite different need of the judicial system to protect the integrity of existing organizations of issues and parties by eliminating "interlocutory" litigation, as in the second sentence of section $10(\mathrm{c}){ }^{36}$ When that need controls, a fully developed position might not be a "reviewable act" under 10 (c) until the completion of the "case," even though it would be viewed as appropriate for immediate review if it appeared in another context.

The timing and organization of questions for review are approached again in section 10(b), where in the "absence" or "inadequacy" of a "special statutory review proceeding relevant to the subject matter" the Act authorizes declaratory judgments, injunction proceedings, and habeas corpus as vehicles for review of "reviewable acts." These are independent proceedings, focusing upon the question precipitating the demand for authoritative resolution. One might read the statute as making such proceedings available for the review of all positions the adoption of which is not first communicated in the course of some form of "enforcement" proceeding or "adjudicatory rule-making" to which a special review proceeding is attached, since for such reviewable acts a special proceeding would be "absent." But the Act does not speak of the absence of special proceedings for review of the challenged action. It speaks of the

32. See, e.g., Algonquin Gas Transmission Co. v. FPC, 201 F.2d 334, 338 (1st Cir. 1953) (Magruder, J.) (the challenged order "really should be regarded as carved out of the main proceeding and as partaking of the nature of a separate proceeding' $)$.

33. See, e.g., Bator, Finality in Criminal Law and Federal Habeas Corpus for State Prisoners, 76 HARv. L. REv. 441, 451-53 (1963).

34. See note 322 infra; text accompanying notes 264,320 infra.

35. See text accompanying note 216 infra.

36. See Phillips Petroleum Co. v. Brenner, 383 F.2d 514, 517-18 (D.C. Cir. 1967); text accompanying notes $340-42$ infra. 
absence of special proceedings "relevant to the subject matter." The "subject matter" in reference must be that of the case proposed to be formed for direct review, and the search for other cases "relevant" to that subject matter opens the question of just what is the "subject matter" of an enforcement review proceeding. Is it the sanction or the situation of those individuals specifically involved rather than the validity of general positions as such, as common-law jurisprudence might suggest?37 Does it include questions that might be finessed in disposing of the "case"? More generally, there is an unanswered question of timing in the notion of the "absence" of special proceedings relevant to the subject matter of the proposed case; for even if one can conceive substantive criteria for the designation of other relevant proceedings, can such proceedings be said to exist if they are not already underway? Can review be postponed because of the potential availability of future cases as vehicles for review? Is the "absence" contemplated by the Act "absence" from the statute books or absence in fact?

These problems have to do with the resolution of questions about positions taken outside the cases for which special review proceedings are provided. It may be noted, however, that even questions which do arise in the context of an ongoing adjudicatory proceeding could be broken out under section $10(\mathrm{~b})$ if the special review proceeding is persuasively "inadequate," 38 and inadequacy would seem particularly marked when persons not subject to sanctions or not involved in the adjudication seek to challenge the administrative position. For them, the special proceeding might even be viewed as "absent." On the other hand, a careful reader of the Act might won-

37. See Wolff v. Selective Serv. Bd. No. 16, 372 F.2d 807, 825 n.6 (2d Cir. 1967) ("Furthermore, it is not altogether clear that an alternative exists to this [injunction] suit in which the legality of the administrative sanctions here imposed may be contested. Certainly should these appellants be found unfit for service for an unrelated reason or not be called to service at all, the merits of their claim can never otherwise be heard. Yet the chilling effect of the Government's sanction would persist unabated.").

38. Special statutory proceedings may be "inadequate" in "adjudicatory rulemaking" as well as in administrative enforcement. In a proceeding whose length is measured in years and whose record in rooms, both the parties involved and those not involved may wish to step outside the "case" and determine the legality of an agency position that assumes institutional form during the litigation. See Pharmaceutical Mfrs. Assn. v. Gardner, 381 F.2d 271 (D.C. Cir. 1967). Cf. Lever Bros. Co. v. FTC, 325 F. Supp. 371 (D. Maine 1971). The position may begin at that point to affect planning and the behavior of officials in other contexts, but authoritative resolution of the question "in the case" is distant, and often contingent: a reviewing court may very well find it possible to sustain or invalidate the rule without reaching all the challenged agency positions that appear in the course of its promulgation. See Willapoint Oysters, Inc. v. Ewing, 174 F.2d 676, 682-83 (7th Cir.), cert denied, 338 U.S. 860 (1949). Cf. Algonquin Gas Transmission Co. v. FPC, 201 F.2d 334, 338 (1st Gir. 1953). This possibility is particularly likely where the "rule" is a complex cluster of interrelated requirements issued together and reviewed as a unit. E.g., In re Revising the Regulations for Foods for Special Dietary Use, 31 Fed. Reg. 15746 (1966). 
der whether the mere existence of the special review proceeding does not define the contours of a "case" and therefore invoke the dichotomy already noted between "preliminary and intermediate action" and "final actions." If so, the action broken out of the special review proceeding under section $10(\mathrm{~b})$ because of its "inadequacy" might be viewed as "unreviewable" under section 10(c) because it is only "intermediate."

Whatever the outcome of reflection on these readings, general doubts are introduced by the Act's reference to review of agency action "in civil or criminal proceedings for judicial enforcement" just after the apparent authorization of independent review proceedings in the absence or inadequacy of relevant "special" proceedings. The clause "except to the extent that prior, adequate, and exclusive opportunity for such review is provided by law,"39 suggests that this part of section $10(\mathrm{~b})$ is meant to preserve an option rather than to prescribe the normal mode of review. The interpretation that review must occur in enforcement proceedings unless Congress makes specific exception would read the prior authorization of direct proceedings out of the Act since they are not designated as exclusive. The more intriguing question is whether a proceeding for judicial enforcement of an agency position can be viewed as a "special statutory review proceeding," and, if not, whether such enforcement review must logically be excluded in considering the availability of immediate and direct review. ${ }^{40}$

Judicial review of agency adjudications under special procedures provided by an organic statute can, as we have noted, ${ }^{41}$ generally be characterized as "enforcement review." But such proceedings are not "civil or criminal proceedings for judicial enforcement," 42 which would have to do with the judicial application of statutory sanctions either for the violation of statutory prohibitions such as those against adulteration or sale without registration or for ultimate resistance to administrative orders. The principal difference between those judicial proceedings based upon jurisdiction to enforce and those based

39. APA § 10(b), 5 U.S.C. § 703 (Supp. V, 1965-1969) (emphasis added).

40. One court has faced the question but provided no answer. General Motors Corp. v. Volpe, 321 F. Supp. 1112 (D. Del. 1970). A party to an enforcement proceeding under the Motor Vehicle Safety Act, 15 U.S.C. \$§ 1381-1425 (Supp. V, 1965-1969)), brought an action to declare "unlawful and void" the defect notification order being enforced. The court observed that to argue "that the enforcement action is the special statutory review proceeding under the Vehicle Safety Act . . . seems a strange interpretation of that language, particularly in the context of the second sentence of $\& 703, "$ but went on to evaluate the "adequacy" of the enforcement proceeding in terms of the $A b b o t t$ ripeness test. 321 F. Supp. at 1124.

41. See text accompanying notes 15-16 supra.

42. APA § 10(b), 5 U.S.C. § 703 (Supp. V, 1965-1969). 
upon jurisdiction to review lies, to be sure, principally in where the burden of initiating the proceedings is placed. That it is often only a formal difference becomes clear when one contemplates the complexities introduced by the interpretation of organic statutes to authorize third-party enforcement as well as third-party review. ${ }^{43} \mathrm{But}$ without such a jurisdictional distinction it is difficult to give content to the phrase "special statutory review proceedings"; and if such a distinction is recognized, direct review seems to emerge as the norm, once questions about the existence, relevance, and adequacy of special review proceedings have been passed. This pattern would be logical and even inevitable. The form of proceeding specifically tailored by Congress to resolve a question must take precedence over the form chosen by a challenger, and courts are bound to shift the question to the designated proceedings.

This assurance of direct review dissolves, however, when it is remembered that a position, though final, is "reviewable" under 10 (c) only if it is "made reviewable by statute" or if there is no other "adequate" remedy in a court. ${ }^{44}$ These conditions upon the availability of review could be read as a paraphrase of the conditions upon review in a direct proceeding enunciated in section 10(b). Agency action "made reviewable by statute" could be action for which a special statutory review proceeding has been provided. "Final agency action for which there is no other adequate remedy in a court" could be action for which special statutory review proceedings are absent or inadequate. If this reading is not adopted, however, the proceedings that take precedence under the rubric of "reviewability" are not confined to "special statutory review proceedings," and may therefore include "civil or criminal proceedings for judicial enforcement." The degree to which the demands and needs for the resolution of questions arising from the administrative process are in fact met by the APA would thus turn upon what makes alternatives to direct review "adequate" substitutes. Does "adequacy" mean equivalency or something less? Is it to be measured by the importance of the question to the challenger or its importance to the regulatory system as a whole? May substitutes be potential or must they be at hand?

Moreover, the timing and mode of review authorized by sections 10(b) and 10(c) of the Act are also subject to manipulation through the concept of "standing" set out in section 10(a). ${ }^{45}$ The same person

43. See note 169 infra.

44. 5 U.S.C. \$ 704 (Supp. V, 1965-1969).

45. 5 U.S.C. \& 702 (Supp. V, 1965-1969). 
worried about the same question-the same "agency action"-may, at least as a matter of language and logic, be declared to "[suffer] legal wrong because of [that] action" or be "adversely affected or aggrieved by such action within the meaning of any relevant statute" 46 at one time but not at another. Legal wrong or adverse effect may be recognized when the question is presented in an enforcement action, but not when it is presented in some other form, for instance, an application for a declaratory judgment.

Finally, section 10 as a whole is introduced by the proviso "[e]xcept to the extent that ... statutes preclude judicial review." 47 Although the point is not beyond argument, it may be assumed that preclusion of all review, which would be constitutionally suspect, is not meant, and that the "preclusion" to which the proviso refers is a partial one, covering particular forms or a particular timing of review. ${ }^{48}$ The conceptual machinery of the Act thus provides one more possibility for the denial of direct review and a shift of a question to another case even where an organic statute specifies no alternative proceeding. If, for instance, injunctive or declaratory proceedings or habeas corpus were to be found "precluded," review would be automatically shifted to enforcement proceedings under section $10(\mathrm{~b})$ or postponed until the emergence of "the" final agency action under section 10 (c).

In sum, neither a guarantee nor a presumption of direct review can be found within section 10 . But it is fair to say that nothing in the APA clearly requires a court to shift a question out of a case created specifically for the purpose of resolving it, and that the Act grants courts full authority to adjust the timing and form of review to meet the evolving needs of the regulatory process.

\section{B. Administrative Declaratory Orders: Section $5(d)$}

The effect of the obscure section $5(d)^{49}$ upon the structure of the Act also warrants a brief word. A provision for administrative declaratory orders "to terminate a controversy or remove uncertainty" might at first glance be viewed as giving definitive form

46. 5 U.S.C. \& 702 (Supp. V, 1965-1969).

47. 5 U.S.C. \& 701(a)(1) (Supp. V, 1965-1969).

48. See the discussion of Abbott in pt. VI. infra. The Court in Abbott addresses the question whether pre-enforcement review is precluded.

49. "Adjudications ...

(d) The agency, with like effect as in the case of other orders, and in its sound discretion, may issue a declaratory order to terminate a controversy or remove uncertainty." APA § 5(d), 5 U.S.C. § 554(e) (Supp. V, 1965-1969). 
to what we have heretofore described as independent review proceedings, resolving many of the arguments over timing and the substantive relationships between questions that are possible under and even engendered by the language of section 10. A question could become a "case" at the administrative level with an internal logic of its own, both procedural and substantive, and thus relieve courts of much of the difficulty of deciding whether that question should be treated as a renegade from some other case currently awaiting or soon to be presented for decision.

But section 5(d) does not play such a role. It is, first, a discretionary authorization, and an agency need only decline to $\operatorname{act}^{50}$ to throw a question into the lottery of jurisdictional litigation. Moreover, many agencies have apparently made no provision whatever for implementation of section $5(\mathrm{~d}) .{ }^{51}$ Second, and more important, the introductory language of section 5 seems to limit the availability of section 5(d) declaratory orders to "case[s] of adjudication required by statute to be determinated on the record." 52 Although it has been suggested that the introductory limitations of section 5 are meant to apply to section $5(\mathrm{c})$, and not to section $5(\mathrm{~d}),{ }^{53}$ the use of the term "order" in section 5(d) arguably excludes all forms of "rulemaking" in view of the definition of "order" in section 2(d)..$^{54}$ What this would mean is that administrative declaratory judgment procedures are lacking in virtually every situation in which there may be doubt about the timing and form of a challenge to an announced agency position.".5 An "adjudication required by statute to be de-

50. It might be possible, of course, to seek review of a refusal to issue a declaratory order for abuse of discretion. See S. Doc. No. 248, 79th Cong., 2d Sess. 25 (1946); $1 \mathrm{~K}$. Davis, Administrative Law Treatise § 4.10, at 276-78 (1958).

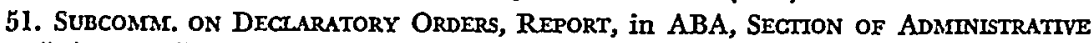
LAw, 5 ANNUAL REPORTS OF COMMTTtEes 3 (1968) [hereinafter ABA REPORT].

52. APA § 5(d), 5 U.S.C. § 554(a) (Supp. V, 1965-1969) (emphasis added). See Sellers, Adjudication by Federal Agencies Under the Administrative Procedure Act, in TaE Federal Administrative Procedure act and the Administrative Agencies (G. Warren ed. 1947); S. Doc. No. 248, 79th Cong., 2d Sess. 204 (1946).

53. See $1 \mathrm{~K}$. DAvis, supra note 50, § 4.10, at 272-74.

54. APA \& 2(d), 5 U.S.C. \& 551(6)-(7) (Supp. V, 1965-1969), provides:

(6) "order" means the whole or a part of a final disposition, whether affirmative, negative, injunctive, or declaratory in form, of an agency in a matter other than rule making but including licensing;

(7) "adjudication" means agency process for the formulation of an order; (emphasis added).

55. It has also been argued that limitations on the $\S 5(d)$ authorization need not be viewed as a pro tanto withdrawal of whatever inherent powers agencies may have to issue declaratory orders in other situations. I K. DAvis, supra note 50, § 4.10, at 274. Some agencies do appear to believe that they are issuing declaratory rulings without reliance on \& 5(d). See ABA REPORT, supra mote 51. Cf. Pennsylvania R.R. v. United States, 363 U.S. 202 (1960) (ICC order). But what may be termed the traditional view is that jurisdiction to grant declaratory judgments and thus create a "case" is not inherent and must be explicitly provided by statute. See U.S. DEPT. OF JUSTICE, AT- 
termined on the record after opportunity for an agency hearing"'5s is generally an enforcement or licensing proceeding begun at the administrative level.

Section 5(d) may therefore permit a person subject to direct regulation and potentially exposed to sanctions to initiate the proceeding and thus to advance the timing of the challenge and avoid the risk of paying for the opportunity to challenge. Section 5(d) may also permit questions to be broken out of a "case of adjudication" whose form is already molded. But if the agency wishes to choose the context of review, ${ }^{57}$ it may be able to fall back upon its discretion; and if it wishes to avoid problems associated with a reasoned exercise of discretion, the agency may simply omit formal procedures for preenforcement initiative altogether. In any event, section 5 (d) seems to do nothing for persons who are not the potential objects of sanctions, and nothing for the review of agency positions that do not require, or even admit of, a hearing on a record-those interpretations and statements of practice, policy, law, and procedure raising essentially legal controversies based on undisputed facts or facts that can be conveyed by briefs. Section 5 (d) may be inapplicable even to rules required by statute to be made on a record after a hearing (and subject to sections 7 and 8), since such "adjudicatory rule-making" proceedings are not strictly speaking "cases of adjudication." 58

It is, of course, possible to argue that every rule, interpretive or formal, issued without procedure, issued under section 4,80 or issued after an "adjudicatory" hearing-in short, every agency "action"-must have an eventual bite in an enforcement proceeding. The relevant sanctions may be beside the point for practical purposes. The agency may have a choice only between unauthorized jawboning ${ }^{60}$ and license revocations that would shatter an industry

toRney General's Manual on the Administrattve Procedure Act 59 (1947). The result is that most declaratory relief to "terminate a controversy or resolve uncertainty" produced by the adoption of an administrative position has been initiated at the judicial level.

56. 5 U.S.C. § 554(a) (Supp. V, 1965-1969).

57. For a discussion of the importance of such power to choose, see pt. VII. A. 5. infra.

58. Curious procedures have arisen to terminate peripheral uncertainties in such proceedings, for instance those regarding intended coverage. They include staged testimony by agency officials or collusive testimony by expert witnesses and "clarifications" of regulations published in the Federal Register which are in fact substantive amendments. E.g., In re Foods for Special Dietary Use, 31 Fed. Reg. 15731 (1966). Their use indicates a need for statutory reform.

59. See note 9 supra and accompanying text.

60. See Austern, Expertise in Vivo, 15 AD. L. REv. 46, 50 (1963). See also text accompanying notes $240-43$ infra. 
and be politically unthinkable. But unless the agency position could make a difference in the outcome of some enforcement proceeding against a particular person on particular facts requiring an evidentiary hearing and a record, it is mere philosophizing and, indeed, could not have the effect necessary to spark a claim for timely and independent review. Therefore, the resolution of controversies regarding these rules can be analyzed as a preliminary part of a "case of adjudication," inchoate though it be. There is arguably no difference, except in timing, between clarifying an ambiguity (for instance, the intended coverage of a rule) before an enforcement proceeding and breaking that same question out of an enforcement proceeding after it has begun. The considerations to be taken into account, the kind of arguments to be made, the procedures, and the outcome should all be the same. Thus, one may claim that the introductory limitations of section 5 are logically meaningless for section $5(d)$, even if technically applicable.

It is doubtful that section 5(d) was actually meant to permit breaking questions out of an enforcement proceeding, actual or hypothetical. That would be too much at war with the classic view of the organizing function of the "case" and the jurisprudence of common-law decision-making in which rules remain immanent. Much more likely is that a section 5(d) declaration was meant to substitute for a sanction and to come at the end of a full onthe-record adjudication. ${ }^{61}$ Under section 2(d), an "order" is after all what emerges from a process of adjudication, ${ }^{62}$ and section 5 (d) speaks of declarations as "orders." Furthermore, section $5(\mathrm{~d})$ seems to assume that an evidentiary record will be involved, as may the very notion of adjudication itself; and the requirement of a record would tend to force an administrative declaratory order to the end rather than the beginning of a "case."

But there is recent support in Red Lion Broadcasting Company, Incorporated $v . F C C^{63}$ for the expansive argument that questions may be broken out of hypothetical enforcement proceedings under section $5(\mathrm{~d})$. There a letter to a broadcaster taking the position that the fairness doctrine required him to provide free rather than sponsored time for reply for a person who had been personally attacked on the station was held a reviewable order because the agency could have commenced an enforcement proceeding in which

61. Cf. FPC v. Metropolitan Edison Co., 304 U.S. 375, 383-85 (1938).

62. 5 U.S.C. \$ 551(7) (Supp. V, 1965-1969).

63. 395 U.S. 367 (1969). 
that position could have been questioned ${ }^{64}$ and, as the Court explained in a footnote, "could, under the Administrative Procedure Act, have issued a declaratory order in the course of its adjudication which would have been subject to judicial review."B5 Reviewability of the letter was expressly based on section $5(\mathrm{~d})$. The effect of this rationale is twofold. It makes clear that section $5(\mathrm{~d})$ does not merely graft another remedy onto standard procedures, but rather permits the creation of a new case. It goes further and in effect permits breaking a question out of a case that has not begun and may never materialize. The second effect is the more intriguing, for the Court leaps over agency discretion to withhold the issuance of a section $5(d)$ order by declaring ex post facto that the announcement of a position is to be treated as such an order, although it is not so designated. Agency discretion is permitted, exercised, and exhausted in adopting and announcing the position; it does not extend to the choice of a mode of announcement that would govern the timing and organization of judicial review.

Definitive conclusions cannot, of course, be drawn from a footnote in one opinion. And there are limiting factors in Red Lion. The letter announcing the agency position was not addressed to the world but to a specific broadcaster in a specific fact situation. It is arguable, therefore, that this rationale of reviewability does not extend to general announcements, rules and quasi-rules. But the effect on others of announcement of the personal attack rule is not different because the announcement comes in the form of a letter. It was spread and meant to be spread in industry literature, and the Red Lion litigation was viewed as a "test case," a case in which by definition all persons similarly situated have an interest. ${ }^{66}$ Moreover, the Court had no difficulty in joining Red Lion with United States v. Radio and Television News Directors Association, ${ }^{67}$ in which it reviewed rules adopted later and announcing the same position. There was, second, a factual record of sorts in Red Lion in the exchange of letters. That record, however, was irrelevant to the question for review and was forgotten when the case was merged with the review of the rule-making proceeding. There is, finally, the Court's notation of the fact that the agency had argued for review-

64. 395 U.S. at 372 .

65. 395 U.S. at $372-73$ n.3.

66. Other broadcasters faced a decision whether to allow any personal attacks at all to be aired on their stations.

67. 395 U.S. 367 (1969). 
ability and the petitioner had waived objections to the "procedure of the adjudication"68 - that is, to the hypothetical character of the adjudicatory enforcement proceeding contemplated by the Court. But the government cannot by consent confer jurisdiction on the Court. ${ }^{69}$ And the Court itself referred to the omitted adjudicatory proceedings as "formalities." Red Lion may therefore represent the revitalization of section $5(\mathrm{~d})$ as an explicit source of direct review.

\section{The Response of the Courts}

At the judicial level the development of review mechanisms did not take the sinuous path through section 10 of the APA, clarifying the ambiguities one by one until the Act could stand as a coherent guide and guarantee. For many years section 10 was viewed principally as a restatement of the common law that had been developed before its enactment. ${ }^{70}$ Instead, the courts responded in ad hoc fashion to the demands for judicial review prior to or outside enforcement proceedings or special statutory proceedings, steadily expanding the opportunities to resolve questions in a timely and authoritative way for those imaginative enough to piece the developing strands together.

\section{A. Expansion of the Terms "Order" and "Proceeding" in Special Statutory Review Provisions}

The Urgent Deficiencies Act, ${ }^{71}$ the Administrative Orders Review Act (Hobbs Act), ${ }_{32}$ and other special review statutes confer jurisdiction to review "orders" or "final orders" of specific agencies. In a series of cases the term "order" was made flexible enough to include interpretive "rules," 73 whose effect was far less obvious or precise than an order to a particular person to do a particular thing or suffer a particular sanction. By $1970 \mathrm{Mr}$. Justice Marshall was able to say

68. 395 U.S. at 372 n.3.

69. FCC v. National Broadcasting Co., Inc., 319 U.S. 239, 246 (1943).

70. See Byse \& Fiocca, Section 1361 of the Mandamus and Venue Act of 1962 and "Nonstatutory" Judicial Review of Federal Administrative Action, 81 HARv. L. REv. $308,321,328$ (1967).

71. 28 U.S.C. $\$ \S 2321-25$ (1964).

72. 28 U.S.C. $\$$ 2341-5I (Supp. V, 1965-1969).

73. See, e.g., Frozen Food Express v. United States, 351 U.S. 40, 44 (1956). The Court recognized the immediate impact of the position on the planning and bargaining of shippers and carriers, "shaping the manner in which an important segment of the trucking business will be done." 
for a unanimous Court: "[T]he argument that the order lacked finality because it had no independent effect on anyone . . . has the hollow ring of another era. Agency orders that have no independent coercive effect are common."74 In tandem with this expansion of trigger points for judicial review to embrace the point where the administrative position crystallized, there was a narrowing of traditional requirements for formal indices that the administrative mind was made up. In simple semantic terms, the definition of what constituted a recognizable "rule" enlarged while the definition of an "order" was enlarging to include what were designated as "rules." Thus, the broadcaster obtained review of the letter that he had received in Red Lion. ${ }^{75}$

Where the Hobbs Act or similar provisions written into organic statutes seemed to require that reviewable "orders" be entered in an administrative "proceeding," courts also dispensed with technical criteria for the recognition of a "proceeding"-which would have permitted an agency to choose the time and context of review simply by choosing whether to announce its position in one particular form -and defined "proceeding" as whatever process preceded the appearance of an "order." Complaints, charges, demands to show cause, or petitions for statements of position might be couched in the polite discourse of correspondence; the furnishing and sifting of facts and information might take place in conferences or further exchanges of correspondence; and orders might take the form of queries about what step an affected person proposed to take next. Hearings, records, evidence, findings, and sanctions designated as such became unnecessary. ${ }^{76}$ Certainly agencies could not be kept to a designated procedure for announcement of a position any more than a procedure could be established for cracking a joke. It is the effect, the receipt of information, that matters; and the information that a position has been adopted is not wiped away by the simultaneous

74. Port of Boston Marine Terminal Assn. v. Rederiaktiebolaget Transatlantic, 400 U.S. $62,70-71$ (1970).

75. 395 U.S. 367 (1969). Review by third parties has taken the same course. In Banzhaf v. FCC, 405 F.2d 1082 (D.C. Cir. 1968), cert. denied sub nom. Tobacco Institute, Inc. v. FCG, 396 U.S. 842 (1969), a private citizen obtained review of a letter that had been sent at his request to a broadcaster.

76. See, e.g., Medical Comm. for Human Rights v. SEC, 432 F.2d 659, $668-69$ (D.C. Cir. 1970), cert. granted, 401 U.S. 973 (1971); Sun Oil Co. v. FPC, 266 F.2d 222, 226 (5th Cir. 1959), affd., 364 U.S. 170 (1960); Cities Serv. Gas Co. v. FPC, 255 F.2d 860, 863 (10th Cir.), cert. denied sub nom. Magnolia Petroleum Co. v. Cities Serv. Gas Co., 358 U.S. 837 (1958); Phillips Petroleum Co. v. FPG, 227 F.2d 470, 474 (10th Cir. 1955), cert. denied sub nom. Michigan Wisconsin Pipe Line Co. v. Phillips Petroleum Co., 350 U.S. 1005 (1956). But cf. FPC v. Metropolitan Edison Co., 304 U.S. 375, 382-83 (1938); Texaco, Inc. v. FPC, 317 F.2d 796, 805 (10th Cir. 1963), revd., 377 U.S. 33 (1964). 
perception that the manner in which the information was conveyed was unorthodox. ${ }^{77}$

\section{B. Contraction of Equity Prerequisites}

When courts did not choose to fill the terms "order" and "proceeding" with special meaning and thus were foreclosed in particular cases from basing their jurisdiction on explicit review provisions written into organic statutes, or when such provisions did not exist, it was found possible to rely on general equity jurisdiction. ${ }^{78}$ At least since the decision in American School of Magnetic Healing v. McAnnulty, ${ }^{79}$ a petition to a district court for an injunction has been viewed as the creation of a "case" in which an agency position could be reviewed.

It might be thought that the traditional prerequisites of equity jurisdiction, "irreparable injury" and "inadequate remedy at law," would make a suit for an injunction a peculiarly unsuitable vehicle for immediate and direct review. Both requirements affect timing and context. A demand for "irreparable injury" before the court considers the merits should postpone resolution of the challenge to the last possible moment, depending of course upon whether the spreading effects of the agency position happen to inflict "irreparable injury" early or late upon those active in the regulatory field who happen to bring the problem to the courts. A search for "adequate remedies at law" should result in the transfer of the issue to other substantive contexts, in which the resolution of questions may be different and will have a different timing at the very least. "Adequate" does not, after all, mean optimum. It refers to the threshold at which a presumption against judicial review begins to operate.

As the use of injunctive proceedings to review administrative rulings developed, however, the prerequisites of equity jurisdiction were abandoned. The adequacy of other remedies was simply not

77. See Columbia Broadcasting Sys., Inc. v. United States, 316 U.S. 407, 416 (1942). Information that process was lacking might tell a person that the ultimate implementation of the position through specific sanctions backed by judicial force can be postponed until process has been supplied. One can, of course, be too cynical about the utility of judicial remand for reconsideration under proper procedures. Jaffe \& Vining, Exclusive Jurisdiction and Remand, in L. JAFFE, supra note 20, at 715-17; Jaffe, Judicial Review; Question of Law XIII: Remand, Utility or Futility?, id. at 589. But certainly on questions of the sort chiefly examined in pre-enforcement review, the sociology of an administrative agency, centrally organized and teleological, makes a change of opinion on reconsideration much less likely than it would be within the
rather different dynamics of the judicial system.

78. See, e.g., Shields v. Utah Idaho Cent. R.R., 305 U.S. 177, 183-84 (1938); L. JAFFE, supra note 20, at 193; Byse \& Fiocca, supra note 70, at $319-20,325$.

79. 187 U.S. 94 (1902). 
investigated, 80 and "irreparable injury" became in practice "substantial injury." 81 The result was a vehicle for pre-enforcement resolution of questions about an administrative position that was available to sophisticated courts and counsel, whether or not the form in which the position was announced was that contemplated by the explicit review provisions written into the organic statutes.

\section{Control of Discretion and Inaction}

Judicial handling of discretionary actions and the related problem of the "negative" order followed a similar course. Over time the touchstone of review has become a showing that the agency has adopted a fixed position to guide its activity and the activity, therefore, of those in the field. Such a showing puts the discretionary decision outside the APA and common-law exemption from all review of actions "commited to agency discretion by law" 82 and renders the agency position susceptible to "legal" "challenge. In the words of Citizens To Preserve Overton Park, Incorporated $v$. $V_{0 l p e}{ }^{83}$ there is review if there is "law to apply." 84 The appearance of a fixed agency position has even determined timing and mode of review in the face of strong evidence of congressional intent that review be confined to a "case" of enforcement. The series of decisions enlarging pre-induction review of selective service board determinations is a study in the emergence of a test of "jurisdiction" grounded in "the nature of the challenge being made"-that is, "legal

80. Though it continued to be relevant to the applicability of other limiting doctrines, such as ripeness and exhaustion, which were not in terms associated with the choice of form of proceeding.

81. Professor Davis has outlined the history of this development. See $3 \mathrm{~K}$. DAvIs, supra note 50, $\$$ 23.04-.08, at 307-34, esp. at 310 n.15. See also ICC v. Atlantic Coast Line R.R., 383 U.S. 576, 604 (1966) ("[T] he test of reviewability [by suit for injunction] is no longer pregnant with the concept of irreparable injury to the same extent as when the negative order doctrine held sway, and we do not mean to resurrect the strict equity approach."); United States v. ICC, 337 U.S. 426 (1949); Stark v. Wickard, 321 U.S. 288 (1944); Shields v. Utah Idaho Cent. R.R., 305 U.S. 177 (1938); L. JAFFE, supra note 20, at 411 .

82. APA § 10, 5 U.S.C. § 701(a)(2) (Supp. V, 1965-1969).

83. 401 U.S. 402 (1971).

84. 401 U.S. at 410, 413-14. For a rationale of judicial review of the implicit rules guiding agency discretion, see L. JAFFe, supra note 20, at 555-56, 568-64; Berger, Administrative Arbitrariness: A Synthesis, 78 YALE L.J. 965 (1969). If the standard of review is "abuse of discretion," it can be analytically resolved into "error of law," the standard applicable in most other pre-enforcement or direct review proceedings. See L. JAFFE, supra note 20, at 181-83, 586-89. For arguments in favor of nonreviewability, see Saferstein, Non-Reviewability: A Functional Analysis of "Committed to Agency Discretion," 82 HARV. L. REv. 367 (1968). For a discussion of the legislative history of the APA in this connection, see $4 \mathrm{~K}$. DAvis, supra note 50, § 28.16, at 15-30 (Supp. 1965). 
challenges ... that do not require review of a factual and discretionary decision of a board." 85

Moreover, when abuse of discretion is alleged, courts search in a comparatively direct way through the diverse evidence of institutional thinking for agency positions of general applicability. Perhaps in the flux and acknowledged formlessness of discretionary activities there has been nothing to obscure judicial perception of the fixed point. No clusters of issues and procedures on their own way to the courts float about ready to capture the question raised by the adoption of the position and limit its relevance to less than the administrative program as a whole. Perhaps the acknowledgment that the position will have an effect in situations immune from judicial scrutiny highlights the need for review. ${ }^{86}$ Thus, by 1967 a district court could say in assuming jurisdiction:

The correspondence of the responsible Treasury official in this instance is, to be sure, in part obscure and in part ambiguous. The Court construes it, however, as taking the position in behalf of the Treasury Department that the Secretary does not have the discretionary power under the statute to promulgate a regulation fixing the time for paying the tax involved in this action in accordance with the plaintiff's request. ${ }^{87}$

The mode of announcement in that case was correspondence, not even of the somewhat formal kind used by some agencies such as the

85. Breen v. Selective Serv. Local Bd. No. 16, 396 U.S. 460, 468-69 (1970) (Justice Harlan, concurring). After enactment of an inartfully drawn clause apparently intended to preclude pre-enforcement review ("No judicial review shall be made of the classification or processing of any registrant ... except as a defense to a criminal prosecution ..." 50 U.S.C. App. § 460(b)(3) (Supp. V, 1965-1969)), Oestereich v. Selective Serv. Sys. Local Bd. No. 11, 393 U.S. 283, 237 (1968) allowed pre-induction review of a "blatantly lawless" denial of a "statutory exemption" when there had been "no exercise of discretion" by a board in evaluating evidence. Breen extended pre-induction review to illegal "deferments." As Justice Harlan points out, the availability of review now seems to turn on an advance decision on the merits. See, e.g., Stella v. Selective Serv. Sys. Bd. No. 66, 427 F.2d 887, 889 (2d Gir. 1970). But there is review nonetheless, and a denial of "jurisdiction" thus comes close to a rejection of the challenge on the merits. See generally Donahue, The Supreme Court vs. Section 10(b)(3) of the Selective Service Act: A Study in Ducking Constitutional Issues, 17 UCLA L. REv. 908 (1970); Winick, Direct Judicial Review of the Actions of the Selective Service System, 69 Mich. L. REv. 55 (1970).

86. The legitimacy of the immunity of discretionary activity makes acknowledg. ment possible. When there are opportunities for agency jawboning a position will have similar hidden effects, but since such activity is not fully legitimate the effects cannot be recognized and explicitly weighed in any particular case without reflecting upon agency personnel. This, like the difficulty in ascertaining the effects of a position on the agency's own operations, argues in favor of a general rule of reviewability. See text preceding note 240 infra.

87. Schenley Indus., Inc. v. Fowler, 275 F. Supp. 356, 357 (D.D.C. 1967) (Foltzoff, J.). 
Federal Communications Commission (FCG) or the SEC. The source of the announcement was a "responsible" official, who the court realistically recognized could as much speak for the agency-at least to the sensitive ears of the regulated-as the statutorily designated head. In Office Employees Local 11 v. NLRB, ${ }^{88}$ the Court resolved the question whether the National Labor Relations Board had legal jurisdiction over labor unions acting as employers when, in dismissing a particular case, the Board "recognized ... a blanket rule of exclusion over all nonprofit employers." 89 Before, the Board had "declined jurisdiction on an ad hoc basis," stating that " [T] he policies of the Act would not be effectuated by its assertion of jurisdiction in that case." "90 The mode of announcement was a preliminary decision in an enforcement proceeding. There was, of course, no other easily discernible way in which the question of lack of power could reach the courts. But this was not the ground of the decision to review-a regretted inability to postpone resolution of the issue. It was sufficient that the position had crystallized. And in Gitizens To Preserve Overton Park, after holding that the Federal Aid Highway and Department of Transportation Acts make protection of parkland a factor to be given paramount importance in exercising discretion to authorize federal funds for the construction of highways through public parks, the Court turned enforcement review on its head and ordered that a record be made, by testimony of agency officials if necessary, to determine "whether the Secretary properly construed his authority" 91 in the case in issue. The mode of announcement of the agency position that cost or community disruption might be given equal weight in the balancing of relevant factors had been agency counsel's argument that there was no jurisdiction to review the challenged exercise of discretion.

Abandonment of the "negative order" doctrine was connected with judicial willingness to review agency refusals to exercise discretion. In shifting away from the rule that an agency must take some positive action to bring about a change in the status quo before review is appropriate, the courts necessarily shifted focus from the application of ultimate sanctions to the impact of the position upon the development of the administrative scheme as a whole. ${ }^{22}$ Maintenance of the status quo, in the words of Rochester

88. 353 U.S. 313 (1957).

89.353 U.S. at 318.

90. 353 U.S. at 318 (emphasis original).

91. 401 U.S. at 416.

92. See Wisconsin v. FPC, 373 U.S. 294, 810 (1963) (review of agency's stay of its own proceeding in light of the public interest in rate regulation). 
Telephone Corporation v. United States, ${ }^{93}$ is "an exercise of the administrative function": "The nature of the issues foreclosed by the Commission's action and the nature of the issues left open, so far as the reviewing power of courts is concerned, are the same."94 This development has proved particularly important in recent years for "third-party" challengers-persons who are affected by and are perhaps the primary intended beneficiaries of the regulatory scheme, but who are not directly subject to sanctions, and whose interests often lie in obtaining positive action from the agency. ${ }^{95}$ Their participation in the process of judicial review has been steadily expanded in the development of the doctrine of standing, to which we shall now turn.

\section{Divorce of Standing and Sanctions}

Where a presumption operates that courts are to be reluctant to review-where, in effect, agencies have been viewed as legislatures and postponement of confrontation by self-restraint has been deemed a judicial virtue ${ }^{96}$ - the doctrine of standing serves something of the same function as the doctrine of "ripeness." If a person is directly subject to regulation and therefore subject to an enforcement action, he may find direct review of a position blocked for want of "ripeness." But if a person is a third-party challenger and the appropriateness of enforcement review is not in issue, he may find his way blocked by lack of "standing." Beyond the constitutional function of assuring a controversy, a finding of standing, like a finding of ripeness, has served to express judicial appreciation of the need for review of the issue. Standing has therefore expanded with increasing judicial sophistication and a change in the presumption regarding the desirability of judicial intervention.

Columbia Broadcasting System v. United States $(C B S)^{97}$ broke what many believed to be new ground in recognizing standing to challenge a regulation in persons not directly subject to administrative control because the regulation

is addressed to and sets a standard of conduct for all to whom its terms apply. It operates as such in advance of the imposition of sanc-

93. 307 U.S. 125 (1939).

94. 307 U.S. at 142.

95. See, e.g., Medical Comm. for Human Rights v. SEC, 432 F.2d 659 (D.C. Cir. 1970), cert. granted, 401 U.S. 973 (1971); Environmental Defense Fund, Inc. v. Hardin, 428 F.2d 1093 (D.C. Cir. 1970).

96. See, e.g., Eccles v. Peoples Bank, 333 U.S. 426, 432 (1948).

97. 316 U.S. 407 (1942). 
tions upon any particular individual. ... When ... the expected conformity to [regulations] causes injury cognizable by a court of equity, they are appropriately the subject of attack . . . It is no answer to say that the regulations are addressed only to the Commission .... .88

The judicial review that thereupon became available was untrammeled by the linear time scale, the canons of relevance, and the focus on an isolated and specific result imposed by a progression from policy formation to concrete application in the image of the common law.92 Prior to CBS, FCC v. Sanders Brothers Radio Station ${ }^{100}$ had already begun to divorce judicial review from traditional remedies or sanctions, and thus from the core of common-law jurisprudence, by accepting jurisdiction to resolve a question despite explicit recognition that the complaining member of the regulated industry was not "legally wronged." Sanders opposed the issuance of a license to a station that would compete for Sanders' listeners. Adverse effect in fact through increased competition made him a trustworthy adversary for purposes of jurisdiction under Article III. ${ }^{101}$ But in the view of the Court the injury to him and the agency's lack of consideration of that injury were not reasons why the agency action might be invalid as inconsistent with statutory requirements. Sanders was entitled to no remedy against the effect that made him complainincreased competition-because national communications policy envisioned free competition. He was, instead, a private attorney general arguing the public interest and had standing as such.

Of course, invalidation of the competition-promoting regulation in Sanders protected the legally unprotected "private" interest. And some believe that the Court overstated the case it had to decide, and that in fact Sanders' competitive position and hurt were relevant to regulatory policy and the public interest and could constitute a form of "legal wrong." 102 But this reading is quite compatible with a view which seems sounder analytically and which, as we shall see, is reflected in the current doctrine of standing, that all reasons arguable in a court for any purpose have to do with the protection of public

98. 316 U.S. at 418.

99. In $C B S$, the FCC announced that it would not renew the license of a licensee which entered a specified contract with a network. 316 U.S. at 408 . The sanction thus did not run against the complaining networks, which were not as such subject to FCC jurisdiction.

100. 309 U.S. 470 (1940).

101. U.S. CoNsT. art III.

102. See L. JAFFE, supra note 20, at 515-28. 
values and never with the vindication of merely private interests. ${ }^{103}$ And however one categorizes the interests and injuries that led to the challenge and were found sufficient for standing in Sanders and $C B S$, the fact remains that the opinions in these cases exposed the public function of judicial review and, with it, the anomaly of allowing its timing and outcome to be governed by the situation of a particular litigant. ${ }^{104}$

At the same time, and again under the standing rubric, the courts have recognized an increasing number of systemic effects upon the regulatory field that can result from the mere crystallization of an agency position. Put another way, they have expanded the legally cognizable "interests" that create a need for review far beyond the interest of not suffering a direct sanction. United States $v$. Storer Broadcasting Company ${ }^{105}$ went beyond the loss of advantageous relationships, which prompted the Court to review the chain broadcasting regulations in $C B S$, and explicitly recognized the effect of regulations on planning:

Storer cannot cogently plan its present or future operations. cf. Frozen Food Express v. United States, 351 U.S. 40, 43-44. It cannot plan to enlarge the number of its standard or FM stations, and at any moment the purchase of Storer's voting stock by some member of the public could endanger its existing structure. These are grievances presently restricting Storer's operations. ${ }^{106}$

In Flemming v. Flordia Gitrus Exchange ${ }^{107}$ - the start of the complex

103. But see L. JAFFE, supra note 20, at 527-28, who suggests that whether the review is as of right or within the discretion of a court might be made to depend on whether the standing of the challenger is based on a "private" or the "public" interest.

104. Jurisdiction in $C B S$ was based upon $\S 402(a)$ of the Communications Act of 1954, ch. 652, \& 402(a), 48 Stat. 1098, as amended, 47 U.S.C. \& 402(a) (1964), which authorized suits to enforce, enjoin, set aside, annul, or suspend any "order" of the Commission except orders granting or refusing licenses or permits. Jurisdiction in Sanders was based upon $\S 402$ (b) of the Communications Act, ch. 652, § 402(b), 48 Stat. 1093, as amended, 47 U.S.C. \& 402(b) (1964), which provided for appeal to the Court of Appeals for the District of Columbia Circuit from an order granting or refusing a license or a permit by any "person aggrieved or whose interests are adversely affected by any decision of the Commission granting or refusing such application." We have noted the similarity between the term "order" in review provisions appended to organic statutes and the term "agency action" in the APA. See pt. IV. A. supra. Section 402(a) of the Communications Act thus resembles the authorization of direct. review in $\$ 10(\mathrm{~b})$ of the APA. The similarity between the formula in $\S 402(\mathrm{~b})$ and the definition of the "right of review" in § 10(a) of the APA is evident. The APA could thus be substituted for the statutory basis for review in CBS and Sanders. All that is added by the Communications Act is venue in the Court of Appeals for the District of Columbia Circuit for certain review proceedings.

105. 351 U.S. 192 (1956). Cf. Frozen Food Express v. United States, 351 U.S. 40 (1956) (planning and the definition of a "final order").

106. 351 U.S. at 200.

107. 958 U.S. 153 (1958). 
series of administrative and legislative events leading to the Toilet Goods litigation that will occupy us below ${ }^{108}$-the Court relied upon the field's need to know, to know even the worst, in maintaining jurisdiction despite a question of mootness. ${ }^{109}$ Congress had by special act stayed enforcement of a Food and Drug Administration (FDA) determination that colors that might be harmful in high dosages could not be cleared for use in low dosages. The Court said:

The statute accordingly operates as a legislatively ordained stay of the Secretary's order insofar as it affects the present respondents and those similarly situated. . . [W] agree with the parties that the matter before us is not moot. The Secretary's order was the promulgation of a general rule, prospective in operation, and the facts of the respondents' business are such that if the order is upheld, there will be a practical effect on them even during the span of the temporary legislation. Accordingly, the respondents remain persons adversely affected by the Secretary's order, and it is proper for us now to determine the legal situation in regard to them when the temporary legislation expires. ${ }^{110}$

Most recently, the Supreme Court explicitly approved ${ }^{111}$ the line of decisions in the courts of appeal, such as Scenic Hudson Preservation Conference v. FPG ${ }^{112}$ and Office of Communications of the United Church of Christ $v . F P G,{ }^{113}$ that recognized the effect of agency positions on "aesthetic, conservational, recreational" and "spiritual" values as a reason for assuming jurisdiction to review. "We mention these noneconomic values to emphasize that standing may stem from them as well as from the economic injury on which

108. See text accompanying notes 218-27 infra.

109. Under the rubric of "mootness" courts make much the same kind of determination of the need for review of an agency position as under the rubrics of "standing" and "finality." An assertion of "mootness" can often be viewed as merely changing a proceeding from one of "enforcement review" to one of "direct" or "pre-enforcement" review. See A.L. Mechling Barge Lines, Inc. v. United States, 368 U.S. 324, 331 (1961) (dissenting opinion); Southern Pac. Term. Co. v. ICG, 219 U.S. 498, 515-16 (1911) (short term orders). Cf. Division 1287, Street, Elec. Ry. \& Motor Coach Employees v. Missouri, 374 U.S. 74, 77-78 (1963). See also note 244 infra.

110. 358 U.S. at 168. On the merits, the Court sustained the agency position. 358 U.S. at 168 . The three year legislative stay was in fact extended for another two years while negotiations over the Color Additive Amendments of 1960 took place. See Dyestuffs \& Chemicals, Inc. v. Flemming, 271 F.2d 281, 287 (8th Cir. 1959), cert. denied, 362 U.S. 911 (1960).

111. Association of Data Processing Serv. Orgs., Inc. v. Camp, 397 U.S. 150 (1970).

112. 354 F.2d 608 (2d Cir. 1965), cert. denied sub nom. Consolidated Edison Co. v. Scenic Hudson Preservation Conf., 384 U.S. 941 (1966).

113. 359 F.2d 994, 1000-06 (D.C. Cir. 1966). See also Environmental Defense Fund, Inc. v. Hardin, 428 F.2d 1093 (D.C. Cir. 1970); Environmental Defense Fund, Inc. v. Finch, 428 F.2d 1083 (D.C. Cir 1970). 
petitioner relies here." 114 Since the promotion of such "noneconomic" values is the primary object of many regulatory systems, even though they may operate through and upon distinctively economic entities, ${ }^{115}$ the effect of this development is to legitimate the widening and shifting of judicial focus from the effect of the agency position on the challenger to its effect on the regulatory field as a whole, which had been occurring as the conceptual links between review and sanctions were progressively broken. And, of course, as a wider group of "third-party" challengers is brought into the administrative process the apparent problem of short-circuiting enforcement review inevitably declines in importance. ${ }^{116}$ Enforcement proceedings are not in store for third-party challengers.

\section{E. The Consolidation of Doctrine in Light of the Public Function of Judicial Review}

Association of Data Processing Service Organizations, Incorporated $v$. Camp, ${ }^{117}$ and its companion case, Barlow $v$. Collins, ${ }^{118}$ completed the transformation of the doctrine of standing from a part of the blocking apparatus fashioned on a presumption against judicial review into a coherent way of thinking about review in light of a presumption in its favor. In Data Processing a trade association representing sellers of data processing services and a member of the association brought a suit in equity to declare illegal an interpretive ruling by the Comptroller of the Currency published in the Comptroller's Manual for National Banks. The Comptroller had taken the position that, as an incident of the "business of banking" to which the National Bank Act confined national banks, a bank might make

114. 397 U.S. at 154.

115. The Food and Drug Administration, the Highway Safety Agency, and the Communications Commission are obvious examples.

116. One further effect is the elimination of the strained and superfluous "property" analysis left over from property-oriented common law and illustrated by the district court's explanation of trial examiners' standing in Federal Trial Examiners Conf. v. Ramspeck, 104 F. Supp. 734 (D.D.C.), affd., 202 F.2d 312 (D.C. Cir. 1952), revd. on the merits, 345 U.S. 128 (1953):

The court is of opinion that the examiners have such standing. While it may be conceded that the dominant purpose of the act was to guarantee even-handed administrative justice and not to confer benefits upon hearing examiners, it appears that Congress, as a means of obtaining this dominant purpose, clothed examiners with the distinctive professional status mentioned above. . . The court therefore is of opinion that the hearing examiners became vested with a property interest in maintaining a distinctive professional status and have standing to seek legal redress against steps which will relegate them to an inferior status.

104 F. Supp. at 738 (emphasis added). See notes 121-22 infra; text accompanying note 122 infra.

117. 397 U.S. 150 (1970).

118. 397 U.S. $159(1970)$. 
data processing services or its data processing equipment available to its customers and to other banks. The National Bank Act ${ }^{119}$ provided no specific provision for review of the Comptroller's rulings. The court of appeals conceived the "test of federal jurisdiction" to be whether the "litigant has standing to challenge competitive injury." 120 Finding that the petitioners "private interest" in avoiding competition was not one "entitled to protection" and holding that the APA created no new legal rights, the court denied review for want of standing. ${ }^{121}$ The Supreme Court reversed, and restated the nature of the case: the petitioners "seek to challenge a ruling by respondent Comptroller." Whether they had a private "legal interest" was irrelevant to standing in administrative law. ${ }^{122}$ Recognizing that rules of standing have been based on "selfrestraint for [courts'] own governance," the Court announced a broad new test- "whether the interest sought to be protected by the complainant is arguably within the zone of interests to be protected or regulated by the statute or constitutional guarantee in question." 123 This is the only showing-beyond injury in fact "economic or otherwise" - that is necessary to become "entitled to judicial review of 'agency action" " under the APA as one "aggrieved by agency action within the meaning of a relevant statute." ${ }^{24}$ Here the Banking Act "arguably brings a competitor within the zone of interests

119. 12 U.S.C. $\S \S 21$ to $215 \mathrm{~b}$ (1964).

120. 406 F.2d 837, 838-39 (8th Cir. 1969) (emphasis added).

121. $406 \mathrm{~F} .2 \mathrm{~d}$ at $843 \&$ n.12. The court concluded that where one has not been specifically designated a "private attorney general" the reason for the assertion of judicial power must be the alleged invasion of a "property right" or a right analytically indistinguishable from a property right. $406 \mathrm{~F} .2 \mathrm{~d}$ at $840 \mathrm{n} .6,843$.

122. 397 U.S. at 153. In Barlow v. Collins, 397 U.S. 159 (1970), the Court was faced with something more than the old problem of competitive injury. Tenant farmers who were eligible to participate in the Upland Cotton Program and receive subsidy payments in advance of the growing season challenged a regulation of the Secretary of Agriculture that expanded the purposes for which the payments might be assigned to include the payment of cash rent for land used for planting. Like caged men in sharkinfested waters, the tenant farmers sought to prevent an increase in their freedom, alleging that landlords would demand cash rent in advance and thus deprive them of their opportunity to use the cash to escape their dependence upon the landlord for their personal and farming supplies. The lower courts held that the farmers had been granted no "property right in being restrained" and that the Food and Agriculture Act provided no review proceeding, and denied review for want of standing. 398 F.2d 398, 401-02 (5th Cir. 1968). The Supreme Court reversed and applied the rule of Data Processing.

123. 397 U.S. at 153 (emphasis added).

124. 397 U.S. at 157. The court of appeals viewed its jurisdiction as based simply on the existence of a federal question (under the banking laws of the United States) and on that basis applied what it deemed to be the common law of standing. See 406 F.2d 837, 838 (8th Cir. 1969). The Supreme Court brought in \$ 10 of the APA. 
protected by it," and one likely to be financially injured "may be a reliable private attorney general to litigate the issues of the public interest in the present case."125

With such a concept of standing, judicial review of administrative action is no longer an analogue of a common-law case in which the disposition of a general question of law is merely a step toward and subsidiary to the question of what happens to the parties. It is rather an explicit examination of whether legislated public policy is being advanced by the positions of the agency entrusted with its promotion. The principal harm in irrational or ultra vires governmental action or inaction is seen as the impairment of the functioning of the social system in its pursuit of chosen values, rather than as the disappointment of individual expectations. And the broader and more systemic the recognized impact of the agency position, the more imperative is an opportunity for resolution of doubts about its legality.126

\section{397 U.S. at 156.}

126. To emphasize the fundamental doctrinal change it meant to achieve, the Court quoted and explicitly overruled the test for standing announced in Tennessee Elec. Power Co. v. TVA, 306 U.S. 118, 137-88 (1939), which conditioned judicial revicw upon a showing that "the right invaded is a legal right-one of property, one arising out of contract, one protected against tortious invasion, or one founded on a statute which confers a privilege." The dissenting and concurring Justices agreed that "conditioning standing on a showing by the plaintiff that the challenged governmental action invaded one of his legally protected interests" is a "discredited requirement." See 397 U.S. at 167. As an example of what had been discredited, they referred to the statement of the "private substantive legally protected interest" test in the opinion in Associated Indus. v. Ickes, 134 F.2d 694, 700 (2d Cir. 1943), which had, prior to enactment of the APA, viewed judicial review as indistinguishable from litigation between private parties if the organic statute made no specific provision for judicial review. "Unless," Judge Frank had explained,

the citizen first shows that, if the defendant were a private person having no official status, the particular defendant's conduct or threatened conduct would give rise to a cause of action against him by that particular citizen, the court cannot consider whether the defendant officer's conduct is or is not authorized by statute; for the statute comes into the case, if at all, only by way of a defense or of justification for acts of the defendant which would be unlawful as against the plaintiff unless the defendant had offcial authority, conferred upon him by the statute, to do those acts.

In view of the Ickes court's ultimate determination that challengers lacking a "private substantive legally protected interest" were nonetheless "persons aggrieved" entitled to seek to "vindicate the public interest" as "private attorney generals" under a special statutory review provision included in the Bituminous Coal Act of 1937 (see 134 F.2d at 699-700, 704-05, 708), it is unlikely that Judge Frank seriously believed that the function of courts in judicial review of administrative action could be the same as that of common-law courts adjudicating private rights. Certainly the Supreme Court has now delivered the coup de grace to any such belief, and delivered it unanimously. See also Port of Boston Marine Terminal Assn. v. Rederiaktiebolaget Transatlantic, 400 U.S. 62, 71 n.20 (1970); Scanwell Laboratories, Inc. v. Shaffer, 424 F.2d 859 (D.C. Cir. 1970). 


\section{Standing and the Right to Diregt Judicial Review of Final Agency Action}

\section{A. Linking the Litigant to the Regulatory System}

For one seeking a solution to the problem of the timing and substantive context of review, Barlow and Data Processing leave open at least two major and related questions. One is the nature of the interests upon which the Court's analysis fixes attention. The other is whether something more than standing is required to make a "case" for direct review: placing the interest sought to be protected within the protected or regulated zone may be all that is necessary to become entitled to judicial review, but review when and how? How much is achieved by the necessary showing?

In cases in which there are modes of review theoretically alternative to direct and immediate review, there has been, as we have noted, ${ }^{127}$ a developing sensitivity to the effects of an agency position on activity within the regulatory field. To take two examples: When the challenger is subject to direct regulation (that is, subject to ultimate sanctions and the continuous necessity of striking a modus vivendi with the agency), his plans and his implementation of plans almost invariably change, regardless of his intention eventually to acquiesce or not to acquiesce in the agency view. He buys less or more of a particular inventory item, instructs his salesmen differently, recalculates investment decisions, redesigns an industrial plant, or views the promotion of the vice-president of one department as more useful than the promotion of another. These are the immediate effects of the appearance of a new fixed point. In themselves, these effects are irrelevant to the statutory policy, for they are neutral, if viewed in isolation, and usually de minimis. The costs may be principally those associated with uncertainty and self-insurance against contingencies. But if others in the regulatory field do likewise, over time there is an ultimate and possibly irreversible effect that may be contrary to the public policy underlying the organic statute, again regardless of the use of sanctions. The immediate effect on activity has been described in terms of an invasion of "interests," and has been the classic reason for a choice of direct and immediate judicial review. Avoidance of the immediate effect has been the "interest" sought to be protected by judicial review now rather than later. The jurisdictional inquiry has been into the manner in which the adoption of the position, if illegal, affects the challenger at the time that he seeks review. 
But the interest sought to be protected in the review proceeding itself, and the only one relevant to the merits, is the interest in avoiding the ultimate effect. Which is the interest relevant to standing under the Data Processing test? If it is the interest in avoiding the immediate and individual effect, it is arguably not an interest with which the statute is concerned as such. If it is the ultimate interest, an interest not personal and de minimis, then an assertion of standing becomes virtually indistinguishable from an assertion of illegality, and a finding of standing becomes a prejudgment of the merits.

Another example may be drawn from the situation of the thirdparty challenger. An agency issues a regulation authorizing the purchase and commercial use of land bearing formerly protected trees. A conservationist wishes to challenge the legality of the regulation on the ground that the agency did not take into account recreational or aesthetic values as it was required to do. The interest in immediate and direct review is of two kinds. One is that the very existence of the agency position leads individuals and local governments to act and plan in such a way that, when the point of destruction comes, the social cost of nondestruction is greater and the recreational value of the trees is in fact reduced. ${ }^{128}$ The other is that the conservationist has an interest in avoiding the necessity of

128. It is now commonplace that the gestation of a new industrial process or a new product is generally much longer than popularly supposed, and that the length of time required to recover the massive capital investment that must be committed to it has led many large businesses to use a unit of seven to fifteen years in their planning and operations. For nontechnical summaries of the literature, see P. DRUCRER, THE Concept of the Corporation (1946); J. Galbratth, The New Industrial State (1968). This development has important consequences for political economy. It should also affect the doctrines of administrative law. A principle of wait and see, a presumption against judicial intervention before actual conflict, assumes that judicial remedies are effective and that their use will be substantially uninfluenced by reliance interests. This in turn is predicated upon a theoretical vision of the market resembling that of Ricardo, in which economic decisions are reversible and in which participants can easily accommodate to a change in constraining circumstances, including legal constraints. In fact, the investment in planning today is staggering. For instance, the study of the feasibility of a pipeline to Alaska is estimated to cost 12 million dollars. Wall St. J., July 16, 1970, at 4, col. 2. With such sums at stake, projected institutional activity is not hypothetical or unlikely, and judicial decisions wasting such sums, for reasons that existed before the actual investment, are no more practical than licensing powers that an agency cannot exercise without destroying the industry entrusted to its care.

Activity in a field can become irreversible in another way, as is well illustrated by the recent case, now at the administrative level, involving a challenge to the FPC's permission to utilities in the Northeast to select a site for the largest power plant in the world, planned to cost 185 million dollars. N.Y. Times, July 9, 1970, at 74, col. 5 . Site study and selection will take several years, but, more important to the propriety of judicial review, the installation is alleged to be part of a vast and interdependent network of installations that, when completed, will be seen to be harmful to various protected environmental values. 
throwing himself under the bulldozer to precipitate a challenge to the legality of the destruction. ${ }^{129}$ Although accommodating the latter interest is generally cited as a reason for choosing immediate and direct review, ${ }^{130}$ it is certainly not one with which a conservation statute is concerned.131 Is it therefore irrelevant to standing as standing is now defined?

The answer may be a qualified "yes." The interests relevant to standing are, if the words and thrust of Data Processing are to be accepted, solely those relevant to the statutory policy. But it is difficult to conclude that the Court has therefore pushed the general principles of judicial review so far that anyone with personally adverse interests can claim standing by making a plausible argument of "ultimate" harm-that the agency action harms values which the regulatory scheme was intended to promote. That would, very simply, make standing turn on adversariness, since anyone who had an argument to make on the merits could make the necessary argument on the issue of standing. The Court seems to be requiring something more. Moreover, Sanders and suits by private attorney generals to promote the public interest seem to be distinguished as "inapplicable" to the Data Processing situation on the ground that

129. In some circumstances a relegation to enforcement review may be unconstitutional. See Reisman v. Caplin, 375 U.S. 440 (1964); Natural Gas Pipeline Co. v. Slattery, 302 U.S. 300 (1937); Oklahoma Operating Co. v. Love, 252 U.S. 33 (1920); Ex parte Young, 209 U.S. 123 (1908); Jaffe \& Vining, in L. JAFFE, supra note 20, at 707. Proceedings in which the regulation actually bites may also provide no opportunity for review. For instance, the legality of the bulldozer's activity may be held irrelevant in a trial on certain charges that might grow out of a confrontation. Disruption-in contrast with true civil disobedience-may be viewed as too socially dangerous a method of obtaining judicial review. Many have doubts today about the legitimacy of even civil disobedience. See President's Commission on the Causes and Prevention of VIOLENCE, REPORT 92 (1969). See also pt. VII. A. 6 infra.

There is the further consideration that when third-party challenge is involved the issue may be moot by the time enforcement review is possible. The trees may be cut down. Only if the enforcement proceeding is viewed primarily as a test of the legality of the agency position, rather than the pursuit of concrete judicial action (a sanction) in which determinations of law are incidental by-products, would a stay of administrative action pendente lite be appropriate; and if the proceeding is viewed as such, there is no reason to introduce the distraction of sanctions. Of course all may not be lost without a stay. There can be test cases, which, if successful, may save a forest at the cost of a few trees. 1968).

130. Cf. Norwalk CORE v. Norwalk Redev. Agency, 395 F.2d 920, 936-37 (2d Gir.

131. Examples can be multiplied. For instance, the hearing examiners in Federal Trial Examiners Conf. v. Ramspeck, 104 F. Supp. 734 (D.D.C.), affd., 202 F.2d 312 (D.C. Cir. 1952), revd., 345 U.S. 128 (1953), had an interest in immediate review of regulations in part because, at the time the regulations could be said to bite, it would be difficult to show that the effect was not due to a legitimate factor unconnected with the regulations. See L. JAFFE, supra note 20, at 96; text accompanying note 278 infra. 
standing there rests on "an explicit provision in a regulatory statute conferring standing." 132

Much more likely is an unspoken premise in Data Processing and Barlow that must be viewed as part of the Court's test for standing. In applying its announced rule, the Court concludes "§ 4 [of the Banking Act] arguably brings a competitor within the zone of interests protected by it."133 Again, "the tenant farmers are clearly within the zone of interests protected by the [Food and Agriculture] Act."134 A finding of standing, in the new and broadened sense of finding a reason for judicial review, may, in the words of the Court, "stem from values" (economic and noneconomic) which are by nature social phenomena, symbols of the public interest. "Ultimate" harm may be the analytic focus. But the challenger must also show that he, as a person or identifiable entity, is active within the regulatory field and therefore regulated directly or indirectly in some substantial and meaningful way. His affairs, that is, must make him subject to the power either of the agency or of others active in the field whom the agency is in a position to control. In deference to history and convention we have used the rough terms "the regulated" to designate persons exposed to the direct sanctions of the agency, and "beneficiaries" or "third-party challengers" to designate persons exposed to indirect constraints; ${ }^{136}$ but the same entity may fall into either group at one time or another, and the distinction is not in itself important to the law of judicial review. What is important is the maintenance of some connection between the effect of the agency position on the initiating challenger and its effect on the promoted or protected value. Where sanctions are in prospect the connection is ordinarily assumed. The directly regulated challenger is after all often an instrument for the achievement of regulatory purposes. Where the challenger claims to be a beneficiary his status as an actor in the field requires some demonstration, particularly when noneconomic values are in issue.

132. See 397 U.S. at 153 n.1. The distinction is questionable because the Communications Act is no more explicit on standing than the APA, and Sanders is cited in the text of the opinion as supporting the APA standing granted to the challengers in Data Processing. (1970).

133. Association of Data Processing Serv. Orgs., Inc. v. Camp, 397 U.S. 150, 156

184. Barlow v. Collins, 397 U.S. 159, 164 (1970).

135. 397 U.S. at 154.

136. See, e.g., text following notes $16,94,116$ supra. 
If the challenger is a corporate institution it should be enough to show a congruence between the purposes of the institution, which give it its identity, and the purposes of the regulatory system. Business institutions, such as Sanders Brothers Radio Station, that are subject to both direct and indirect regulation as well as the various protective associations such as the Citizens to Preserve Overton Park would generally be able to show such a basic harmony of purpose. But if that showing cannot be made, or if the challenger is an individual whose purposes are not easily isolated and classified, then the connection can be established by reference to legislative history, or, failing that, by an extrapolation from the system of direct sanctions. ${ }^{187}$

It remains true, however, that a determination of who is within the zone of protection or regulation involves an inquiry into statutory policy, and something of a prejudgment of the merits. It is also true that, in limiting judicial review more than Article III commands, the doctrine of standing as stated may allow illegal agency action to go unchecked for want of a qualified challenger. Let us pause a moment over these consequences.

Prejudgment is a criticism leveled at the Court's formula by the dissent. ${ }^{138}$ One answer is that the dissent's proposal, a definition of standing as "adversariness" and then a consideration of "reviewability" including "ripeness," allows prejudgment in just as great a degree, but disguised and therefore more dangerous to reasoned decisions. ${ }^{139}$ But there are also positive reasons for accepting pre-

137. See Barlow v. Collins, 397 U.S. at 164 ("The legislative history of the 'making a crop' provision, though sparse, similarly indicates a congressional intent to benefit the tenants"); Association of Data Processing Serv. Orgs., Inc. v. Camp, 397 U.S. at 157 ("The Acts do not in terms protect a specified group. But their general policy is apparent; and those whose interests are directly affected by a broad or narrow interpretation of the Acts are easily identifiable'). In Arnold Tours v. Camp, 408 F.2d 1147 (Ist Cir. 1969), the First Circuit denied standing to travel agencies to protest a Comptroller's ruling that national banks might enter the travel business. The Supreme Court vacated and remanded the case for reconsideration in light of Data Processing and Barlow, 397 U.S. I35 (1970), and on remand the court of appeals read the new tests for standing as requiring a showing of membership in a class with whose protection the Congress was specifically concerned in legislating the public values to be served by regulation. Finding "no scintilla of evidence" of such concern in the legislative history, the court reaffirmed its denial of standing. 428 F.2d 359 (1st Cir. 1970). The Supreme Court reversed, 400 U.S. 45 (1970), and made clear that it had not relied on legislative history or indications of Congressional solicitude for specific private persons in finding standing. 400 U.S. at $46 \mathrm{n} .3$. For an exploration of the difficulties in using legislative history to define the classes meant to be protected by regulation, see Comment, Judicial Review of Agency Action: The Unsettled Law of Standing, 69 Mrcr. L. REv. 540, 555-60 (1971).

138. 397 U.S. at 176-78 (Justice Brennan, dissenting).

139. For a discussion of "ripeness," see pts. VI-IX infra. 
judgment here, quite aside from the advantage to judicial administration of some sifting of cases on the basis of prima facie showings. These reasons are associated with the grounds that may be advanced for limiting initiation of judicial review to persons with an interest in something more than the principle of legality alone. ${ }^{140}$ Limitation of parties is not a positive good except insofar as it contributes to the quality of the judicial review that does occur. As to that, one can perhaps discern in the required link between the asserted harm to the challenging entity and the asserted harm to regulatory values a confession of residual weakness. The doctrine of standing protects the courts against exposure to arguments by persons whose real interests are not consonant with the public values that they claim to be protecting. The linkage gives some reassurance that if the challengers' analysis of systemic effects and ultimate harm-necessarily complex and intellectually tiring-is erroneous but accepted, and the agency action is reversed, the consequences will not be entirely negative. The health of the challenger may in itself promote the health of the system. ${ }^{141}$ Moreover, detailed examination of the way in which the challenger is affected and the way in which those effects are related to the operation of the regulatory system is itself useful as a prelude to consideration of the more general issues of legality on the merits. The result may be a more sophisticated inquiry at that point, sensitive to what has been called the sociology of the law. ${ }^{142}$

The most tangible reasons that can be advanced, however, have to do with the form and consequences of review proceedings, a matter that will also engage us below. Concentrating control over the initiation and management of judicial review in the hands

140. We may put aside a bald desire to conserve the time of courts and agencies, as well as the promotion of judicial self-restraint and noninterference in the administrative process except in aid of individuals suffering a concrete wrong. As reasons for drawing a line, the former is arbitrary and the latter at war with the newly stated presumption in favor of judicial participation in maintaining the public interest through the administrative process.

141. Cf. Jaffe, In Reply to Mr. Austern, 15 AD. L. REv. 66, 70 (1963).

142. Standing limitations may be in considerable part simply a reflection of problems of proof. A claim by the Audubon Society that it is hurt by the destruction of protected trees and that it is active in the regulatory field may be easily accepted, but a similar assertion by a birdwatcher might not. The institution can demonstrate that its purposes are congruent with those of the statute regulating the field. There would be nothing new in such a distinction between institutions and individuals, although it may not have had to be applied in administrative law before. AngloAmerican law and indeed society are built upon the creation of organizing entities not greatly affected by internal teleological conflict, which have limited and identifiable interests and whose larger fortunes serve as a gauge of group values. If, for instance, an agency position made the Audubon Society wither, we might well be more concerned about the consistency of the position with legislated policy than if a birdwatcher went into a decline. 
of the regulated and the beneficiaries may be some guarantee of prior participation in and awareness of the ongoing administrative process. This in turn may mean that the agency position will be presented in its most crystallized form, or comprehensively in all its aspects. It may mean that the problem can be negotiated out since the parties may well be known to one another and have a number of going conflicts to which they must assign priorities. ${ }^{143}$ It may mean that litigation will be withheld until its implications are understood, since the possible complainants are likely to communicate their intentions to one another. It may mean that the arguments made by those in control of the litigation will be relatively informed and complete, so that some precedential weight can be given to a negative as well as a positive judicial decision. And it may mean that the litigation will be publicized through industry or other group channels so that intervention or consolidation of cases is more likely and more entities will be contributing to the courts' decisions and bound by them. Once the public function of judicial review is admitted, and courts no longer view themselves as sitting essentially to settle disputes between individuals over personal rights, tests for standing may thus have a double function. They may continue as before to ensure that there are reasons for judicial review in light of its purpose (even though its purpose has changed); and they may also now have to serve as criteria for the choice of litigants. Since the claim is no longer necessarily personal, the choice is no longer obvious, and some litigants will be able to assist the decision-making process far more than others. ${ }^{144}$

Finally, in drawing a line between those who are connected with the regulatory field and those who are not, it is unlikely that illegality will go unchecked. In the administrative context "illegality" describes a conclusion that values are being ignored or given improper weight. With standing given to third-party challengers, the danger that the agency and the regulated will together maintain a status quo at odds with public policy and immune from review is met; and an administrative position that does not excite either a direct beneficiary or an entity subject to regulation is unlikely to be "illegal" in this sense.

143. Even where third-party challengers are concerned, there is a tendency to litigate through associations that have continuity and a variety of institutional objectives, just as do directly regulated entities.

144. In a direct review proceeding, however, improvement of the decision-making process can also be achieved after standing is granted and jurisdiction is accepted 


\section{B. The Presumption of Judicial Review}

We have examined the nature and function of the showing now required for "standing," as a prelude to the question, Does judicial review automatically follow a finding of standing? For if standing is now founded upon a plausible demonstration of ultimate harm to the statutory policy, without regard to the degree of immediate harm to the challenging entity except insofar as a showing of present and personal harm is involved in concretely demonstrating the systemic effect or in linking the challenger to the system, it is difficult to believe that review would thereafter be abandoned for reasons having to do with the degree and kind of harm suffered by the challenger. ${ }^{145}$ The focus is, from the beginning, the impact of agency action upon public values. If that impact is found sufficient to invoke review under the criteria announced by the Court, an inquiry into whether the individual challenger needs review at this time as much as he thinks he does, or whether he personally may have other opportunities for review, would seem beside the point.

There are indications in the opinions that the Court does expect immediate judicial review to follow a finding of standing, and that the end of the inquiry under the rubric of standing pursuant to the newly rationalized criteria set forth ends litigation over jurisdiction. "The remaining question," the Court stated in Data Processing after applying its standing tests, is whether judicial review has been precluded. ${ }^{146}$ In answer, the Court applied the presumption enunciated in Abbott in favor of review, demanding specific evidence that Congress contemplated withholding review rather than the reverse, which the court of appeals had sought, evidence that Congress had specifically provided for review. Any further inquiry into "reviewability" or "justiciability" was omitted, despite a dissent on precisely that point. "We hold," the Court concluded, "that petitioners have standing to sue and that the case should be remanded for a hearing on the merits." 147

In Barlow the Court could have but did not ask whether land-

through invitations to intervene or through transfer and consolidation of cases separately initiated. See text accompanying and following note 217 infra.

145. Any more than review is abandoned when the Government is seeking the court's declaration in an enforcement suit and there is a change in the situation of the party who happens to be the object of the suit. See note 109 supra; text accompanying note 300 infra.

146. 397 U.S. at 156.

147. 397 U.S. at 158 . 
lords had in fact demanded assignments of benefits to secure the payment of rent as a condition of leasing land, or whether if landlords did do so a suit could not be brought at that time, perhaps against a landlord, perhaps against an official making a payment to a landlord pursuant to such an assignment, to test the legality of the agency position in a concrete fact situation. Instead, after finding standing the Court addressed the question of reviewability solely in terms of statutory preclusion and agency discretion.

Whether agency action is reviewable often poses difficult questions of congressional intent; and the Court must decide if Congress has in express or implied terms precluded judicial review or committed the challenged action entirely to administrative discretion.

-...

The Administrative Procedure Act [section 10(a)] allows judicial review except where "(1) statutes preclude judicial review or (2) agency action is committed to agency discretion by law."148

The Court met the Government's claim of discretion, as one might expect, ${ }^{149}$ with the observation that a fixed point had emerged about which a legal issue could be raised. ${ }^{150}$ The presumption in favor of review disposed of preclusion. There was no search for any "other adequate remedy in a court" before the position was declared "reviewable" and the "case ... remanded to the district court for a hearing on the merits." 151

It would not be startling to learn that the determination of standing now determines the when and the how of judicial review. For at least two decades the Court has expressed its conclusion that pre-enforcement review was available by stating simply that standing existed under the APA. In Shaughnessy v. Pedreiro'162 the issue was whether a person had a right to immediate and direct review of a deportation order by declaratory judgment, or whether in light of the organic statute review must be postponed until the agency had acted upon its order and habeas corpus was possible. Section 10(a), the standing provision of the APA, "entitles" any person "aggrieved" to judicial review. Section $10(\mathrm{~b})$ includes both habeas corpus and

148. 397 U.S. at 165.

149. See the discussion of the reviewability of questions associated with the exercise of agency discretion in pt. IV. C. supra.

150. The organic statute authorized the issuance of "such regulations as [the Secretary] may deem proper." 16 U.S.C. $\$ 590 \mathrm{~d}(3)$ (1964). What was committed to agency discretion was at most the decision whether or not to take a position. Cf. City of Chicago v. United States, 396 U.S. 162 (1969).

151. 397 U.S. at 167.

152. 349 U.S. 48 (1955). 
declaratory judgment among the "applicable form[s] of proceeding for judicial review" for one "entitled" to judicial review. Section 10(c) makes final agency action reviewable only if there is no other "adequate" remedy in a court or if the action is "made reviewable by statute." Yet the Court did not view the "right to review" as a right to review some time and in some form and then proceed to choose the time and form. Instead it held that interpreting the organic statute to require a choice of the later proceeding would involve "cutting off the right of judicial review . . . in part," which would be at war with the "generous review provisions of the APA" whose "purpose was to remove obstacles to judicial review of agency action."163

The analysis was taken further in another immigration case, Brownell v. Tom We Shung, ${ }^{154}$ where denial of the earlier and direct form of review was characterized not only as a "cutting off" of judicial review but as an exemption from the APA:

Exemptions from the Administrative Procedure Act are not lightly to be presumed ... and unless made by clear language or supersedure the expanded mode of review granted by that Act cannot be modified. 165

It could be argued that the Court's lack of reference in these cases to other obstacles to review previously at large in the common law of judicial review means no more than that when habeas corpus is the alternative, the burden on the challenger makes earlier review so obviously appropriate that mention need not be made of them. But in Tom We Shung the Court recognized that only "technical custody"158 was necessary to support habeas corpus and that "habeas corpus [may be] a far more expeditious remedy than that of declaratory judgment." 157 More important, the Court did not in the end see the cited disadvantages of the later mode of review as relevant to a court's exercise of some retained discretion to choose the time and form of review after standing had been established. Instead, the relative merits of enforcement and direct review "may be weighed by the alien ... after which he may make his choice of the form of action he wishes to use."158

That the Court's direct linkage of review and standing in the

153. 849 U.S. at 51 (emphasis added).

154. 352 U.S. 180 (1956).

155. 352 U.S. at 185 (emphasis added).

156. 352 U.S. at 183.

157. 852 U.S. at 186.

158. 352 U.S. at 186 (emphasis added). 
immigration cases was not simply a reaction to the spectre of habeas corpus is further indicated by United States $v$. Storer Broadcasting Company. ${ }^{150}$ On the same day the rules in issue were adopted, Storer was denied a license on the basis of those rules. Storer's arguments against the legality of the rules could have been reviewed on appeal from the adjudicatory proceeding. If the Court had required an independent inquiry into what the public interest required in Storer's case, Storer's claim that the Commission could not rely on a single factor in exercising discretion-could not, in short, proceed by rules-would have been vindicated. If the Court determined the contrary, that the Commission could proceed by rule, it could turn to the question whether reliance on the single factor of concentration was permissible or sufficient. But after noting the availability of the licensing proceeding as a vehicle for review and raising the question of jurisdiction sua sponte, the Court entertained the declaratory judgment action. The form of the review, though chosen by Storer, rather belied its demand for a specific determination of what was required in its particular case, for on the merits the Court's attention was turned to the general impact and justification of the agency position. This was perhaps what the Court sought. "Jurisdiction," it said, "depends on standing to seek review and upon ripeness." 160 It then made a finding of standing on the basis we have noted before, that planning was affected by the agency position, and proceeded to the merits. Ripeness was not considered.

For Justices Harlan and Frankfurter dissenting, "the implications of the decision undermine much of the settled law on reviewability of administrative action." 161 For them there was no "order" (though there was agency action); no "finality" (though the agency position was crystallized); no "party aggrieved" (though there was a present effect); no "irreparable injury" (though jurisdiction was

159. 351 U.S. 192 (1956). In Storer the agency issued a rule which, in the words of the Court, "declare[d] a present intent to limit the number of stations consistent with a permissible 'concentration of control.' It is but a rule that announces the Commission's attitude on public protection against such concentration." 351 U.S. at 203. The Commission's "attitude" or "intent" or "declared administrative policy" (351 U.S. at 204) was to govern its disposition of specific licensing proceedings. Storer argued, on the merits, that the rule was illegal because the organic act required that the agency make an independent determination of what the public interest required in each specific case after a full and fair hearing, and that the policy was illegal because irrational. 351 U.S. at 205. The former was, in essence, a substantive argument that in exercising its discretion the agency could not make the single factor of concentration dispositive.

160. 351 U.S. at 197 (emphasis added).

161. 351 U.S. at 212-13. 
founded in section 10 rather than equity). ${ }^{162}$ All these objections recall ancient presumptions in favor of avoiding, or postponing in hope of avoiding, judicial intervention and placing it, if impossible to avoid, in an enforcement context where the court may find other grounds for sustaining the agency. All are vestiges of doctrines that have been recast or abandoned in the development of a coherent rationale of judicial review.

Thus fifteen years before Data Processing and Barlow the Court seems to have been proceeding on the new presumption that a demand for judicial review is to be granted unless statutorily precluded, and that whatever judicial discretion remains with respect to the timing and context of review is exercised in answering the question: At what point are challengers adversely affected or aggrieved within the meaning of a relevant statute?

\section{The Divorce of Remedy and Review}

The Court in Data Processing explicitly shifted questions about the existence and kind of remedies available to the challenger, if the agency position should be found "illegal," from the jurisdictional proceeding to the review proceeding itself, ${ }^{163}$ and separated, for purposes of consideration on the merits, questions of illegality and remedy. Before, remedial questions (under the rubric of "legalwrong") had been arguably relevant to the determination of whether there should be a judicial review proceeding in response to the petitioner's challenge. ${ }^{104}$ If in examining the remedial question a court revealed a series of alternative remedies, it inevitably considered the question whether the challenged agency position could not be considered at the time and in the substantive context provided by proceedings leading to such remedies. Now, if Data Processing is followed, such a setting out of alternatives will occur only after jurisdiction to review has been asserted. The divorce of questions of remedy from questions of standing and reviewability should thus have a twofold effect. It should mean that review may be obtained without any showing of a right to a remedy. It should also mean that a mere showing of alternative avenues to a remedy will not defeat review. ${ }^{165}$

162. See 351 U.S. at 207, 209-10, 212-13.

163. 397 U.S. at 158.

164. In Storer the Court had remarked that the APA had introduced "legal wrong" as an element of "standing." 351 U.S. at 197 n.6.

165. Where the "alternative" is a special statutory review proceeding clearly meant to be preclusive, it does defeat a direct review proceeding. But in interpreting 
There are good reasons for this shift. Where comprehensive regulation is in effect, there is no necessary connection between right and remedy-remedy, that is, beyond the review proceeding itself; nor is authoritative resolution of challenges to agency positions fruitless if not accompanied by a judicial order to someone to do something. ${ }^{168}$ The Court's recognition that questions of specific remedy are separate from questions of legality may well be in recognition of, and is certainly justified by, the complexity of the relationships between the agency and those active in the regulatory field-the same feature of the administrative process that makes it so difficult to corral questions into an administrative "case." The agency position may act as a premise for agency action or inaction in a myriad ways-in developing reporting requirements and information flow, in organizing voluntary and cooperative programs, in jawboning (including the use of publicity), in licensing proceedings, in choosing among administrative, civil, and criminal sanctions to enforce broadly phrased regulatory standards, and indeed in shaping, supporting, or opposing legislative programs in Congress. It becomes a rule of relevance, with all the silent and untraceable effects of rules of relevance. ${ }^{167}$ If the impact of the crystallization of

legislative materials the Court seeks specific reasons to conclude that deferral is necessary to the achievement of regulatory goals before it finds preclusion of direct review. See ICC v. Atlantic Coast Line R.R., 383 U.S. 576 (1966); Boire v. Greyhound Corp., 376 U.S. 473 (1964). When no such reasons can be found, direct review proceeds despite the alternative. See Oestereich v. Selective Serv. Sys. Local Bd. No. 11, 393 U.S. 233, 241 (1968) (concurring opinion). In Atlantic Coast Line the Court carefully limited the preclusive effect of the special statutory scheme for the review of an ICC reparations order to the choice of venue in order to preserve as much as possible the advantages of direct review. It required that the forum be chosen by the shipper, to secure various advantages the shipper was meant to have, but permitted the carrier to institute direct review in that forum by cross-proceeding. 383 U.S. at 605.

[I]n some cases there will be some advantage for purposes of assuring the uniform application of the Act in the courts having jurisdiction to directly affect the Commission's order, and we see no justifiable reason for preventing the carrier from bringing the United States into the enforcement court should it so desire. 383 U.S. at 606 (emphasis added).

166. Cf. Baker v. Carr, 369 U.S. 186, 208 (1962) ("It would not be necessary to decide whether appellants' allegations of impairment of their votes . . . will, ultimately, entitle them to any relief, in order to hold that they have standing to seek it . . . They are entitled to a hearing and to the District Court's decision on their claims."); United States v. W.T. Grant Co., 345 U.S. 629, 633 (1953) (enforcement action to vindicate agency position with respect to interlocking directorates under $\S 8$ of the Glayton Act. Respondents dissolved the interlock during the litigation, but the Court maintained jurisdiction and remanded. "The necessary determination [for issuance of an injunction] is that there exists some cognizable danger of recurrent violation, something more than the mere possibility which serves to keep the case alive." (emphasis added)).

167. The central position of enforcement review in the legal thinking of many courts, as the norm from which departures must be justified, and the consequent 
agency positions is upon planning, and if the necessity of planning is a principal reason for direct and immediate resolution of questions concerning the position taken, then the relief afforded by the review proceeding should be seen to consist principally in the encouragement or discouragement of reliance on the position, on the part of both the agency and private parties. ${ }^{168}$ Neither agency nor individual can afford to rely on a position declared illegal. Even if private rights of action to enforce a statute are not recognized ${ }^{160}$ and the agency is left with a monopoly of enforcement powers, there are often ways in which an interested party can bring an agency to enforce, through complaints and adjudication, intervention in licensing proceedings, or participation in rule-making proceedings, all with the purpose of making the agency spell out the grounds for its action or inaction and setting the stage for further judicial review if reliance upon the discredited position should be revealed.170 In the rare cases where there are not such ways, the moral and political force of the legal position established by the direct review proceeding will operate upon the exercise of agency discretion; ${ }^{171}$ and private parties may discover unexpected consequences of reliance upon a position declared illegal, in their inevitable dealings with courts, in fields from tax to antitrust, outside the immediate administrative context. Certainly they will not be protected in their reliance, as they might be if the question of legality were left unsettled, and the beneficiaries

connection between standing and remedy, may have been prolonged by enthusiasm for a geometrical jurisprudence which in its "realism" distinguished "law" and "morality" and insisted that legal right and legal remedy were correlatives, neither of which existed without the other. Cf. Corbin, supra note 18, at 7.

168. See Textile \& Apparel Group, American Importers Assn. v. FTC, 410 F.2d 1052 (D.C. Cir.), cert. denied, 396 U.S. 910 (1969). Despite the agency's opposition, the court took into account the planning needs of the agency itself in determining under the rubric of ripeness that there was a need for immediate review of an agency position. See pt. VII. A. 3. infra.

169. Cf. Mills v. Electric Auto-Lite Co., 396 U.S. 375 (1970); J.I. Case Co. v. Borak, 377 U.S. 426 (1964) (private right of action to enforce Securities Act). In Data Processing the complainants were seeking, inter alia, equitable remedies against the regulated banks. 397 U.S. at 151.

170. See Office of Communications of the United Church of Christ v. FCG, 425 F.2d 543, 548 (D.C. Cir. 1969). Cf. Medical Comm. for Human Rights v. SEC, 432 F.2d 659 (D.C. Cir. 1970), cert. granted, 401 U.S. 973 (1971) (judicial review of SEC determination not to take action against alleged violation of proxy rules); Trailways of New England, Inc. v. CAB, 412 F.2d 926 (1st Cir. 1969); DeVito v. Schultz, 300 F. Supp. 381 (D.D.C. 1969).

171. See ICC v. Atlantic Coast Line R.R., 383 U.S. 576, 605-06 (1966). Over the Government's objection the Court provided for a "direct review proceeding [by] cross action in an enforcement court" where the enforcement action was privately instituted, on the ground that "in some cases there will be some advantage for purposes of assuring the uniform application of the Act in the courts having jurisdiction to directly affect the Commission's order." 
of the regulatory system will not temporarily lose the protection they are meant to have.

\section{The Residual Doubt}

But there are also grounds for doubt that in refashioning rules of standing the Court has made it unnecessary to contend with the doctrine of "reviewability" before the merits can be reached. Most important, the Court has not done so explicitly. Furthermore, insofar as jurisdiction is based upon the APA rather than upon general equity powers, there are inquiries pertinent to the timing and form of review beyond those made by the Court in the standing cases. It will be remembered that the "reviewability" of agency action is addressed in section 10 (c) as well as in the introductory clause of section 10. "Agency action made reviewable by statute and final agency action for which there is no other adequate remedy in a court are subject to judicial review."'172 The Court may have considered it too obvious to state that, in view of the "presumption in favor of review," agency action is "made reviewable by statute" when Congress does not indicate the contrary. The presumption is a rule of statutory construction, which is "reinforced" by and "embodied" in the APA but which has a more general justification and source. ${ }^{173}$ It produces more than a conclusion that section 10 of the APA is applicable. "We hold," said the Court in Barlow v. Collins, "that the statutory scheme at issue here is to be read as evincing a congressional intent that petitioners may have judicial review of the Secretary's action."174 The argument that section 10 (c) is thus satisfied and that the bar to review at the time and in the form chosen by the challenger which might be raised under the second definition of reviewability in 10 (c) can be bypassed may seem to prove too much, for the explicit APA requirement of finality ${ }^{175}$ is logically bypassed also. But courts have not required explicit authority to demand that an agency position be crystallized before review. Even standing is characterized by the Court in Data Processing as a "rule of self-restraint for its own governance."176 And the logic of the APA can be preserved by assuming that the Court viewed the conditions of section $10(\mathrm{c})$ as a paraphrase of those in section $10(\mathrm{~b}),{ }^{177}$ so that the

172. APA \$ 10(c), 5 U.S.C. § 704 (Supp. V, 1965-1969).

173. Abbott Laboratories v. Gardner, 387 U.S. 136, 140 (1967). Cf. City of Chicago v. United States, 396 U.S. 162 (1969).

174. 397 U.S. at 167 (emphasis added).

175. See text accompanying notes 29-36 supra.

176. 397 U.S. at 154.

177. See text accompanying note 44 supra. 
notion of finality remains to guide the courts in choosing the time of judicial review when there is no special statutory review prescribed for the challenged action.

But these are assumptions. However warranted they may be, it is necessary to examine what further showings may be required under present law to obtain immediate and direct judicial review. Certainly the two concurring and dissenting Justices ${ }^{178}$ in Data Processing and Barlow believe that "[w] hen the legality of administrative action is at issue, standing alone will not entitle the plaintiff to a decision on the merits." 170 They go on to discuss what they perceive to be the second hurdle, reviewability, in terms not very different from the Court's discussion of standing. ${ }^{180}$ But they also refer in a footnote" ${ }^{181}$ to the subsidiary doctrine of "ripeness" and do not seem to separate remedial problems from the merits. ${ }^{182} \mathrm{We}$ therefore turn to Abbott Laboratories $v$. Gardner ${ }^{183}$ and its companion cases, Toilet Goods Association, Incorporated v. Gardner (Toilet Goods I) ${ }^{184}$ and Gardner v. Toilet Goods Association, Incorporated (Toilet Goods II), ${ }^{185}$ where the doctrine of reviewability was most recently and fully set forth.

\section{The Problem of Abbott Laboratories v. Gardner}

In $A b b o t t$ thirty-seven drug manufacturers and a manufacturers' trade association sought a declaration of the illegality of an FDA interpretation of the Food and Drug Act and an injunction against enforcement actions based on that interpretation. The Act required that the generic name of a prescription drug be printed "prominently" on the drug's labeling. The agency took the position that the requirement was not met unless the generic name appeared every time the trade name was used, and announced its position in a rule

178. 397 U.S. at 167 (Justices Brennan and White).

179.397 U.S. at 173 .

180. Though, it may be said, in terms somewhat less generally applicable and useful in unifying and rationalizing doctrine. They speak, for instance, solely of statutory "beneficiaries," and do not advert to the situation of persons directly subject to sanctions. 397 U.S. at 174-75.

181. 397 U.S. at 171 n.s.

182. "The same statutory indicia that afford the plaintiff a right to review also bear on the merits, because they provide evidence that the statute protects his class, and thus that he is entitled to relief if he can show that the challenged agency action violated the statute." 397 U.S. at 175 . " " $[$ Where wrongs to individuals are done ... it is abdication for courts to close their doors." " 397 U.S. at 178.

183. 387 U.S. 136 (1967).

184. 387 U.S. 158 (1967).

185. 387 U.S. 167 (1967). 
issued under general authority "to promulgate regulations for the efficient enforcement of [the Act]."186 There had been notice and opportunity to comment pursuant to section 4 of the APA and the agency's own regulations, but no hearing or record. There was no special review proceeding designated by statute. The Government argued, and the Third Circuit agreed, ${ }^{187}$ that the position should stand until the Government chose to rely upon it and an affected manufacturer chose to challenge it in an enforcement proceeding for seizure or injunction involving specific labeling, or in an administrative proceeding to license a specific new drug or to certify a specific antibiotic, or in a criminal proceeding. Any of these proceedings would provide a "concrete factual setting" for resolution of the legal issue whether a generic name that did not appear on the labeling every time the trade name appeared was ipso facto not "prominently" printed within the meaning of that term. The Supreme Court reversed, and ordered the Third Circuit to review the district court's decision on the merits, which had gone against the Government.

\section{A. Abbott and the Consolidation of Review Within the APA}

The opinion in Abbott is significant in three respects. It is the culmination of a development that looked more and more to section 10 of the APA as an independent and comprehensive source of jurisdiction. Pleading practice, at least, had been to invoke the APA chiefly as boilerplate, and to concentrate on bringing the case within the disparate and often tortuous procedures written into the various agency statutes. The courts, as we have seen, ${ }^{188}$ responded in part by revealing that statutory language had a flexibility greater than had commonly been supposed. But in Shaughnessy, Storer, and Rusk $v$. Cort, ${ }^{189}$ the Court reached out explicitly to the APA, and after Abbott review provisions outside the APA should be relevant not to jurisdiction, ${ }^{190}$ but to subsidiary

186. Federal Food, Drug, and Cosmetic Act \& 701(a), 21 U.S.C. \& 871(a) (1964).

187. Abbott Laboratories v. Celebrezze, 352 F.2d 286 ( $3 d$ Cir. 1965).

188. See pt. IV. A. supra.

189. 369 U.S. 367 (1962).

190. Note the question raised by Byse \& Fiocca, supra note 70, at 328-31, whether $\S 10$ of the APA can be viewed as a "grant of jurisdiction" in the strict sense. A conclusion that it is not would impose additional requirements with respect to jurisdictional amount and venue. 
questions such as venue ${ }^{191}$ and scope of review. ${ }^{192}$ Even on such subsidiary questions the APA now seems to have an effect. In City of Chicago $v$. United States, ${ }^{193}$ where jurisdiction was questioned on the basis that there was no "order" of the kind required by the special statutory provisions involved, the Court held that the Abbott "presumption that aggrieved persons may obtain review of administrative decisions" 104 governed its construction of the language of the special review provisions, and referred to the broad APA definition of "order" in reversing the lower courts.

\section{B. Abbott and the Presumption of Direct Judicial Review}

The presumption of judicial review set out in Abbott is, again, a culmination of a prior development. It generalizes the approach taken in the immigration and passport cases discussed above, ${ }^{105}$ in which the Court had required "clear and convincing evidence"198 that Congress intended in the pertinent organic statutes to cut off any of the opportunities for review provided by the APA. The burden of proof in jurisdictional litigation is shifted in all cases to the challenged agency, and is made heavy. To be sure, in the absence of explicit statutory preclusion the Abbott formula required simply that the respondent persuasively "demonstrate" a congressional purpose to preclude review "in the context of the entire legislative scheme,"197 and in its lengthy discussion of the Government's argument the $A b$ bott Court seemed unwilling to rest upon a failure of proof, taking pains to demonstrate in some positive

191. See, e.g., Port of Boston Marine Terminal Assn. v. Rederiaktiebolaget Transatlantic, 400 U.S. 62 (1970); ICC v. Atlantic Coast Line R.R., 383 U.S. 576, 589, 602-03 (1966); Medical Comm. for Human Rights v. SEC, 432 F.2d 659 (D.C. Cir. 1970), cert. granted, 401 U.S. 973 (1971); Environmental Defense Fund v. Hardin, 428 F.2d 1093 (D.C. Cir. 1970). In some cases securing immediate review in a court of appeals rather than in a district court may determine the practical availability of relief. It may also lessen the danger of forum-shopping for harassing stays pendente lite against administrative programs.

192. Cf. ICC v. Atlantic Coast Line R.R., 383 U.S. 576, 594 (1966). Access to special statutory review proceedings may also be important if a significant element of equity discretion is thought by the lower court (perhaps as a result of $A b b o t t$ ) to be involved in granting APA review. Straining for technical inclusion within a guarantee is often more successful than attempting to communicate the merits during arguments ostensibly over the appropriateness of review. See text accompanying note 297 infra.

198. 396 U.S. 162 (1969).

194. 396 U.S. at 164 .

195. See text accompanying notes 152-58 supra.

196. See Rusk v. Cort, 369 U.S. 367 (1962).

197. 387 U.S. at 141. 
way that Congress had no intention to preclude. ${ }^{198}$ But Barlow, three years later, went further and in carefully restating the formula for inference of preclusion emphasized the language not of Abbott but of the earlier immigration cases:

A clear command of the statute will preclude review; and such a command of the statute may be inferred from its purpose. . . It is, however, "only upon a showing of 'clear and convincing evidence' of a contrary legislative intent" that the courts should restrict access to judicial review. ${ }^{199}$

Moreover, Abbott is explicit in stating what was apparent from the language of earlier opinions, that when the APA provides for a right to judicial review "unless precluded" it is providing a right not just to some form of review at some time, but to review in the form and at the time chosen by the challenger from those made available by the Act. A presumption against preclusion acts as much against preclusion of pre-enforcement review as review in general:

The first question we consider is whether Congress by the Federal Food, Drug, and Cosmetic Act intended to forbid pre-enforcement review of this sort of regulation promulgated by the Commissioner. The question is phrased in terms of "prohibition" rather than "authorization" because a survey of our cases shows that judicial review of a final agency action by an aggrieved person will not be cut off unless there is persuasive reason to believe that such was the purpose of Congress. [citations omitted] Early cases in which this type of judicial review was entertained [citations omitted] have been reenforced by the enactment of the Administrative Procedure Act, which embodies the basic presumption of judicial review to one "suffering" legal wrong because of agency action, or adversely affected or aggrieved by agency action within the meaning of a relevant statute, 5 U.S.G. $\$ 702$, so long as no statute precludes such relief or the action is not one committed by law to agency discretion, $\mathbf{5}$ U.S.C. $\$ 701(\mathrm{a}) .{ }^{200}$

And the facts of Abbott make quite clear, if Storer did not, that the resulting presumption in favor of pre-enforcement review is not restricted to situations where enforcement proceedings are infected

198. 387 U.S, at 142-46.

199. 397 U.S. 167. The restatement is more in keeping with the actual practice of the Caurt when it inquires into preclusion of direct review. In addition to evidence of preclusion on the face of the statute, the Court has virtually required that the elimination of any direct review be justified and necessitated by the larger public goals of the regulatory scheme. Preclusive language is made applicable only to the extent that it can be so explained. See Oestereich v. Selective Serv. Local Bd. No. 11, 393 U.S. 233 (1968); ICC v. Atlantic Coast Line R.R., 383 U.S. 576 (1966); Boire v. Greyhound Corp., 376 U.S. 473 (1964).

200. 387 U.S. at 199-40 (emphasis added). Cf. National Automatic Laundry \& Cleaning Council v. Schultz, 443 F.2d 689, 702 (D.C. Cir. 1971): "There is warrant, then, for discerning at least a limited presumption of pre-enforcement judicial review in the case of authoritative interpretive rulings." (Footnote omitted.) 
with the odium of arrest and detention. Enforcement under the Food and Drug Act generally proceeds civilly in rem; and in any event corporations are not arrested when criminal proceedings are commenced, and do not suffer odium when they are convicted. ${ }^{201}$

\section{The Anomaly of Ripeness}

But having said all this, the opinion in Abbott nevertheless demands that the challenger persuade the court that "sufficient" hardship to the challenger will result if pre-enforcement review is "withheld," and that "the issues presented are appropriate for judicial resolution at this time." 202 In short, the challenger, with a "right of review" by "any applicable form of legal action"203 which has been found not precluded in whole or in part, must still move the court to exercise discretion to grant review before he can speak to the merits. Though exercised at the threshold of the suit, the opinion finds authority for such discretion in the "equitable nature" of the declaratory judgment and injunctive remedies to which preenforcement proceedings usually look. This, it says, is the "ripeness doctrine," which has "intricacies."204

Taken as stated, the doctrine seems curiously atavistic. Judicial discretion is not introduced to provide for such occasional and exceptional deviations from the normal course of review as may be shown to be necessary by the respondent, but is rather put as a hurdle that challengers must surmount in every case of preenforcement review. The rule governing the exercise of the asserted discretion is such that the result of the challenger's failure to carry the burden of persuasion is a denial of review. This is a presumption against review, which can be based only upon conceptions of the function of courts in the systematic pursuit of legislated values, and of the proper relationship between courts and agencies, that no longer guide the development of administrative law. ${ }^{205}$ Beyond that

201. But cf. the brief discussion of corporate criminality in NATL. COMM, ON REFORM or Frderal Criminal Laws, Study Draft of a New Federal Griminal Code, lix-Ix (1970).

202. 387 U.S. at 149.

203. APA \$\$ 10(a)-(b), 5 U.S.C. \$\$ 702-03 (Supp. V, 1965-1969).

204. In the following discussion of ripeness, it should be kept in mind that we assume, as we have throughout, that the position challenged is a crystallized and institutional one. Concerns about judicial intereference with administrative processes, which may be relevant to the maintenance and administration of the doctrines of finality and exhaustion, are therefore not involved here. Nor are concerns about judicial interference with administrative programs, which may be handled in the definition of the scope of review and the administration of the law of stays. See text accompanying notes 229-32 infra; pt. $X$. infra.

205. It is perhaps significant that the opinion in $A b b o t$ was written by Justice Harlan, who had dissented in Storer and Rusk against the emerging redefinitions of 
necessary to ensure adversariness, the degree and kind of "hardship" suffered by the parties who happen to initiate the review proceeding should not be relevant to the desirability of examining the impact of a crystallized position upon the operations of the regulated system, if indeed the calculation of "hardship" in these cases is itself a meaningful exercise. ${ }^{208}$ The impact is no less because the particular party suffers less and no greater because he suffers more.

The purpose of a review proceeding in the form of a declaratory action is not protection of an individual from a specific sanction, but the facilitation of planning, the delineation and harmonization of regulatory values, and the protection of the system from irreversible changes that the mere adoption of the position can bring about in any number of ways. ${ }^{207}$ This becomes quite clear when groups with widely varying private interests and suffering greater or lesser "hardship" or "benefit" from the position intervene in a review proceeding at either the administrative or judicial level. ${ }^{208}$ The irrelevance of timing review on whether the agency position "requires an immediate and significant change in the ... conduct of their affairs with serious penalties attached to non-compliance"200 is also clear whenever the initiating challenger is a beneficiary of rather than directly subject to the regulatory system, and generally when the values at stake are noneconomic. There are few grounds for discrimination between the two classes of plaintiffs, and few indeed for imposing greater restrictions on review at the instance of the regulated than on review by third-party challengers. The signal achievement in the last decade of administrative law-whether in

such operative terms as "order," "finality," and "aggrieved" on which APA pre-enforcement review is built. After Abbott, Justice Harlan again had to dissent against the expansion of general notions of standing and justiciability in Flast v. Cohen, 392 U.S. 83, 116 (1968). Fundamental to his thinking has been the premise that "judicial forbearance [is] the part of wisdom" (392 U.S. at 132), which appears in Abbott not just in his attempt to invigorate the ripeness doctrine but in his general concern to prevent the courts from "entangling" themselves and to "protect" the agencies from "judicial interference." 387 U.S. at 148.

Writing for the Court in Barlow, Data Processing, and City of Chicago was Justice Douglas, who in Flast specifically disputed Justice Harlan's premises and, as we have seen, proceeded to develop the administrative law of standing in such a way that it drew only on that part of Abbott which reaffirmed the presumption in favor of review and evoked the objection that the doctrine of ripeness was being forgotten.

206. See note 236 infra.

207. See discussion at text accompanying notes 127-29 supra.

208. For an example of a proceeding in which dozens of contending groups demonstrated the complexity of both the effects and the ultimate choices of public values in. volved in the promulgation of a complex set of regulations seeking to regulate aspects of consumers' diets, see In re Revising the Regulations for Foods for Special Dietary Use, 31 Fed. Reg. 15730 (1966).

209. Abbott Laboratories จ. Gardnex, 387 U.S. 136, 153 (1967) (emphasis added). 
the Supreme Court, in the lower federal courts, or in legislatures ${ }^{210}$ has been the realization of the public function of judicial review, and the elimination of doctrinal anomalies stemming from the historic position of property law and criminal law, with their jurisprudence of private rights, in the business and thinking of courts and lawyers. Nurturing the doctrine of ripeness in a field that has been thus resown should be impossible.

Moreover, linking consideration of the merits to the burden upon the challenger of withholding review requires that the challenger show that he would be personally entitled to some relief if successful in the pre-enforcement review proceeding; there would otherwise be no burden on him from postponing review. But this is precisely the showing of "legal interest" which the Court in Data Processing held need not be made until the "hearing on the merits" which follows a finding of "standing to sue."211 Indeed, the general separation of remedial questions from jurisdictional questions, which seems to follow from Data Processing and Barlow, should put in doubt judicial authority to erect a discretionary barrier to review under the rubric of ripeness since that discretion is drawn from the discretionary nature of the remedies involved.212

Finally, where the thrust of administrative law has been toward the development of guarantees to replace the uncertainty and the resulting cost and delays of jurisdictional litigation that burden and deter judicial review, the ripeness doctrine requires a weighing and balancing which only a denial of certiorari can stop. It inevitably keeps alive jurisdictional questions, on the adverse disposition of which the entire litigating investment may be lost, until the very end of the review proceeding. ${ }^{213}$

210. E.g., Michigan Environmental Protection Act, Mrce. Comp. LAws ANv. 88 691.1201-07 (Supp. 1971).

211. 397 U.S. at 158. Indeed, it need not be made at all. FCC v. Sanders Bros. Radio Station, 309 U.S. 470 (1940). One without a "legal interest" may feel freer to brave the agency in seeking review than one who is subject to licensing authority or other sanctions and for whom loss of the goodwill of agency personnel may seriously affect daily operations. It is noteworthy that much current judicial review is undertaken by trade associations that do not in themselves have a "legal interest" in the sense of a personal right to a remedy.

212. Cf. the observation of the District of Columbia Court of Appeals on taking jurisdiction in a case of pre-enforcement review:

A declaratory judgment, like other forms of equitable relief, is granted only as a matter of judicial discretion, exercised in the public interest. . . . But that kind of discretion is more soundly exercised after the court has probed the merits, and not by way of a threshold consideration.

National Automatic Laundry \& Cleaning Council v. Schultz, 443 F.2d 689, 703 (D.C. Cir. 1971) (Leventhal, J.).

218. The district court ruled in favor of the challenge on the merits in Abbott, 228 F. Supp. 855 (1964), and the court of appeals reversed without reaching the merits. 
If it were not for the companion Toilet Goods cases, ${ }^{214}$ the references to the ripeness doctrine in Abbott could be viewed as a terminological shudder just before the consolidation and simplification of doctrine that occurred in Data Processing and Barlow. To its own question whether sufficient hardship from postponement had been demonstrated, and to the Government's arguments that the only hardship on the plaintiffs was financial, the Court in Abbott replied, in essence, that the plaintiffs had "standing." 215 And the Court seemed to find sufficient answer to its question whether the issues were fit for judicial decision "at this time" in its observations that the questions raised were "legal" in character-which is no more than a reference to the scope of review that would be applied on the merits-and that the regulations were "final agency action" within the meaning of that term as it had been developed-which is no more than to say that the position that they announced had been crystallized and adopted by the institution. ${ }^{216}$

352 F.2d 286 (1965). In Textile \& Apparel Group, American Importers Assn. v. FTC, 410 F.2d 1052 (D.C. Cir.), cert. denied, 396 U.S. 910 (1969), the district court ruled in favor of the challenge on the merits, but subsequently, through another judge, ruled that the case was not "ripe." See 410 F.2d at 1053.

214. See notes 183-84 supra and accompanying text.

215. 387 U.S. at 153-54. At some points in its discussion, the Court seemed to want to view $A b b o t t$ as an obvious case, where the plaintiff faces the choice of giving up asserted "rights" or assuming the risk of conviction, and where withholding judicial review would thus raise constitutional questions. (Cf. National Gas Pipeline Co. v. Slattery, 302 U.S. 300 (1937); Oklahoma Oper. Co. v. Love, 252 U.S. 33 (1920); Ex parte Young, 209 U.S. 123 (1908)). "The alternative to compliance . . . would risk serious criminal and civil penalties . . . ." 387 U.S. at 153.

But the Court had already observed that the agency position would also govern administrative licensing and certification proceedings. 387 U.S. at 152 . Such proceedings are continuously in session, and most active members of the drug industry must resort to them frequently if they are to remain competitive. Thus once the agency had adopted the position no further initiative was necessary, on the part of the agency or the regulated, before the issue was raised in an enforcement context. The plaintiff could comply, at financial expense, until a licensing proceeding and obtain review without the risk of penalty (at least in theory) by declining to fulfill the agency's conditions for a license and appealing the resulting denial of the license.

This does not mean that the Court was wrong in granting pre-enforcement review in $A b b o t t$. It does mean that $A b b o t t$ is not a case in which the reason for pre-enforcement review is hardship to the plaintiff. The specific factors in favor of review in $A b b o t t$ are simply reflections of the reasons justifying the general presumption in favor of pre-enforcement review that the Court announced.

216. Crystallization as an institutional position was indicated in Abbott by a variety of factors: the agency position was formally announced, there was no problem of exhaustion of administrative proceedings with respect to the formulation of the position, the announcement was not by a subordinate official, and the position was not labeled by the agency as tentative. None of these, however, is essential. A reviewable position may be announced informally. It may have institutional status while administrative proceedings are technically still open. A subordinate official may be found to have been speaking for the agency. And agency labels are by no means a reliable guide to the message the agency is in fact conveying to the field. 
Moreover, the procedural flexibility in coordinating and managing pre-enforcement review of the issue and interested parties' participation in it after the merits have been reached, which the Court also draws from the equitable and discretionary nature of the remedies involved, is an important contribution to the case for a generalized right of direct review. The Court emphasized the reviewing court's authority to issue a stay pending the conclusion of other proceedings, to transfer venue, to dismiss without prejudice after intervention elsewhere, to await the joinder of interested though not indispensable parties, and to react to harassment or delay through multiple suits, as an answer to specific objections to pre-enforcement review. ${ }^{217}$ But flexibility is a more positive virtue. Its absence when enforcement proceedings have been initiated and a specific person faces specific sanctions weighs strongly against postponement of review. Quite aside from the possible absence of procedural mechanisms for consolidation in enforcement proceedings, a court's principal concern in determining whether to admit other parties or to await the resolution of related substantive issues in other proceedings must be prejudice to the respondent's litigating strategy, rather than prejudice to a rational and consistent judicial treatment of the general issues involved. Flexible procedures had been developed in the lower federal courts before Abbott and without reference to their cumulative impact on the rationale of pre-enforcement judicial review. What the Abbott opinion has done in collecting these devices together and approving them is to take yet another step to separate and free pre-enforcement review from the concept of the "case" and thus make all the more appropriate a basic presumption in favor of judicial participation in ongoing and interrelated administrative processes.

But the Toilet Goods cases indicate that the ripeness doctrine may not be merely a quaint restatement of the stated presumption in favor of direct review. In Toilet Goods $1^{218}$ the FDA had announced in published regulations that certification service would be denied to a manufacturer that refused government inspectors free access to manufacturing processes and formulae for "color additives." The Court held that the challenged regulations were unquestionably "final agency action," the "agency's considered and formalized

For an exploration of the institutional effects of agency utterances resulting in a presumption of finality for rulings signed by the head of an agency, see National Automatic Laundry \& Cleaning Council v. Schultz, 443 F.2d 689 (D.C. Cir. 1971).

217. 387 U.S. at $154-55$.

218. 387 U.S. 158 (1967). 
determination,"219 and that the issues presented were purely legal and thus within the scope of the review afforded by the proceeding. The Court found that "nothing in the Food Drug and Cosmetic Act . . . bars a pre-enforcement suit under the Administrative Procedure Act . . . and the Declaratory Judgment Act." 220 " [N] less," the Court concluded, "we are not persuaded that the present suit is properly maintainable." 221 The reason was squarely grounded in the doctrine of ripeness:

[J]udicial review of this particular regulation in this particular context is inappropriate at this stage because, applying the standards set forth in Abbott Laboratories v. Gardner, the controversy is not presently ripe for adjudication. ${ }^{222}$

In Toilet Goods $I I,{ }^{223}$ on the other hand, the Court held that the prerequisite of ripeness was satisfied. The FDA had announced in published regulations that it would seek to apply the safety clearance and batch certification procedures of the Color Additive Amendments ${ }^{224}$ to all ingredients in a mixture of substances intended to color the human body, to the mixture itself, and to hair dyes insofar as the danger of an ingredient would not be revealed by the "patch test" required by statute. The challenge was ripe because "this is not a situation in which consideration of the underlying legal issues would necessarily be facilitated if they were raised in the context of a specific attempt to enforce the regulations," ${ }^{225}$ and because the administrative proceeding in which the issues could later be raisedafter a denial of listing and certification-would require a "substantial" amount of "preliminary paper work, scientific testing, and record keeping." ${ }^{226}$ The Court examined the arguments to be presented on the merits and found the issue "a straightforward legal one": whether the agency could "amplify the statutory definition" of "color additive" to include "non-coloring ingredients" and "finished products" and whether the agency could apply the Color Additive Amendments to hair dyes despite a statutory provision that "provides that hair dyes are totally exempt from coverage of the statute."227

219. 387 U.S. at 162.

220. 387 U.S. at 160.

221. 387 U.S. at 162.

222. 387 U.S. at 160-61.

223. 387 U.S. 167 (1967).

224. Color Additive Amendments of 1960, 21 U.S.C. \$\$ 321-76 (1964).

225. 387 U.S. at 171.

226. 387 U.S. at 178.

227. 387 U.S. at 169. 
VII. Administration of the Ripeness Doctrine: Judicial. Choice Between Direct and Enforcement Review

\section{A. Defects in the Calculation of Costs}

The reasoning and the outcome in Abbott and both Toilet Goods cases illustrate the difficulties created by the ripeness doctrine and the inadequacy of its terms of reference for a consideration of the desirability of delayed review.

At the outset it may be useful to note and put aside the Court's omission of any consideration of the effect of the challenge itselfthat is, the effect of the process of litigation-upon the implementation of the agency program. That is quite properly a question of interim relief, which may arise in either immediate direct review or delayed enforcement review. ${ }^{228} \mathrm{~A}$ stay of administrative action during a direct challenge is not automatic or easy to obtain. ${ }^{229}$ Even in an enforcement proceeding, an agency may seek and obtain a stay of private action pending the outcome of the litigation. ${ }^{230}$ The issue whether an administrative program should be brought to a halt or allowed to proceed before the merits are explored is therefore not relevant to a choice of the timing and kind of review proceedings to be had on a question. It is irrelevant, that is, unless one takes the position that there may be a valid public interest in authorizing courts to bring about irreversible changes in a regulated system through judicially created litigation delays. ${ }^{231}$ The appropriateness of a zone of agency freedom to select means for the pursuit of legislated goals (even to the point of supplementing authorized enforcement procedures through the use of informal pressures) is, of course, a relevant consideration in the courts' determination of the scope of

228. Judicial power to stay pending litigation of a "case" is not limited to "cases" in which courts sit to vindicate private or property rights. See Scripps-Howard Radio, Inc. v. FCC, 316 U.S. 4, 14-15 (1942) ("[T] he function of the stay is to avoid irreparable injury to the public interest sought to be vindicated by the appeal. The Communications Act of 1934 did not create new private rights. The purpose of the Act was to protect the public interest in communications. ... [T] hese private litigants have standing only as representatives of the public interest. . . That a court is called upon to enforce public rights and not the interests of private property does not diminish its power to protect such rights. . . . To do so would stultify the purpose of Congress to utilize the courts as a means for vindicating the public interest. . . Courts no less than administrative bodies are agencies of government. Both are instruments for realizing public purposes.").

229. See Jaffe \& Vining, in L. JAFFE, supra note 20, at 687-768.

230. See Jaffe \& Joyce, Temporary Judicial Stays Pending Administrative Action, in L. JAFFE, supra note 20 , at 654 .

231. Such a position would seem inconsistent with both the principle of legality and the premise of administrative regulation of social systems that questions which can be articulated are to be resolved through reason rather than power. 
review or interpretation of congressional delineations of that scope. But that is not the question we treat here, which is whether review of any kind may be had at the time and in the form it is sought and by the person seeking it. ${ }^{232}$

\section{1. "Hardship to the Parties"}

In Abbott there was no inquiry, even of a preliminary and screening kind, into the impact of the "generic-name-every-time" requirement upon the system of prescription drug development and marketing in the United States, which was at bottom what concerned the challengers and the agency alike. To the challengers, the research and marketing structure was built upon the profits derived from trade name competition; to the agency, the structure had no such foundation and in any event the public interest in its maintenance was doubtful. ${ }^{233}$ Of course, these considerations go to the merits of the legal issues, to the evaluation and reconciliation of congressional intentions. But they bear also on the jurisdictional question of delayed review through enforcement proceedings. $A b b o t t$ may serve as an example. An effect of allowing the agency's generic name position to stand unreviewed for any substantial time, which should be relevant to the exercise of discretion to delay review, could be a shift in research plans or a de-emphasis or partial dismantling of the system of detail-man marketing ${ }^{234}$ necessitated by the mere appearance of a new fixed agency position to be taken into account in plans and strategic calculations. Furthermore, if any large number of manufacturers chose to comply while awaiting enforcement review in a test case, there might be a weakening of brand-name identification and a permanent shift in the buying habits of prescription drug consumers. A conclusion that such shifts would be desirable or undesirable, or would cause "hardship" to the industry, is possible only after a determination of the public policy expressed in statute. High-volume generic sales may prove more profitable.

232. As we shall see in pt. VII. C. 2. infra, a court may in fact engage in a process of review in the direct proceeding whatever the outcome on the "jurisdictional" question. The question may then be rephrased: How can a court best make the determinations that it cannot escape making?

233. See Brief for the United States at 4-5, Abbott Laboratories v. Celebrezze, 352 F.2d 286 (3d Cir. 1965); Hearings Before the Subcomm. on Antitrust and Monopoly of the Senate Comm. on the Judiciary, 86th Cong., 2d Sess., pt. 16-26(b), e.g., pt. 16, at 9238-44 (1960) [hereinafter 1960 Hearings]. Some discussion of these questions can be found in Developments in the Law: Deceptive Advertising, 80 HARv. L. REv. 1005, 1104-06 (1967).

234. For a description of the detail-man marketing system, see 1960 Hearings, supra note 233, pt. 16 at $9243-44$, pt. 25 at 14203-08. 
Research may be cheaper and more productive in universities. Distribution of drugs may become more rational-in reaching situations of greatest need-or more equitable. That determination is, in effect, the decision on the merits in a dispute of this kind. ${ }^{235}$ But a conclusion that there is a systemic effect, and that the effect is relevant to the regulatory concerns, is possible without greatly prejudicing the merits and should determine the question of timing. It should also determine the relative advantages of considering the merits in a declaratory proceeding in which members of the industry and perhaps qualified representatives of the medical community and the public, the beneficiaries of the regulatory system, may be freely involved without prejudicing the "rights" of anyone.

Instead of such inquiries, relevant to the nature of the issues and values actually at stake in the case, the Abbott opinion looked narrowly into the costs to the initiating challengers of alternative routes of judicial review. ${ }^{236}$ Since it found sufficient costs to permit

235. The use of drugs is arguably not price elastic. In certain South American countries, for instance, governments were faced with a choice between generic drugs promoted through government channels and trade-named drugs promoted through a private system of detail-men that, it was claimed, would produce wider medical and lay acceptance and usage and ultimately a higher degree of public health. See N. Y. Times, June 2, 1963, \& 1, at I, col. 4; 109 CoNG. REc. 16950-51 (1963). The concern of American courts, faced with a challenge to and a defense of generic drugs, should be to determine whether Congress was principally interested in price, or in use, or even in restricting promotion and overuse, when it made various legislative choices. The appropriateness and need for such a determination has nothing to do with whether a generic system would in fact harm or benefit the prescription drug industry, although such harm or benefit might be relevant to the determination itself.

236. The essential irrelevance of such an inquiry may be illustrated in a formal way by supposing that generic drug manufacturers had initiated the proceedings or intervened and argued that the regulation fell illegally short of congressional intent, much as the data processors in Data Processing argued that the agencies had not sufficiently restricted the activity of others in the regulatory field. In that case the issues upon review of the merits might be the same, but measuring the degree of the "hardship" that the challengers would suffer by reason of delay would not be viewed as legally pertinent to the availability of review. Such challengers, though part of the regulated industry, would be like third-party beneficiaries to whom the ripeness doctrine must be either inapplicable or always applicable since they do not face problems of compliance. They do suffer "hardship" in being unable to plan with certainty and in losing the economic advantages that they could secure if they prevailed upon the merits. But these effects of the existence of the agency position merely give them standing and are not thereafter relevant, except to the merits.

Furthermore, timing review according to the degree of hardship that delay would cause the challenger raises the question of how one recognizes harm when the challenger is an institution. Suppose that in Abbott the challenger, or a member of the bench, or a law clerk, or an amicus proposed that in making its jurisdictional decision the court take into account hardship on middle-aged detail-men whose personal capital, their skill and contacts, could be wiped out by the use of generic names or a shift from detail-man marketing. The explanation for not placing that interest in the scale would probably be that the trade association or the "corporation" which was the complaining party did not itself suffer such hardship, and that consideration of the effect of the agency position on the detail-men should be left to another "case" governed by other policies. But that explanation will not do. An 
review, the narrowness and irrelevance of the inquiry were of no moment. But in Toilet Goods I they were crucial. Finding insufficient cost to the challengers, the Court postponed review without asking what the true concerns of the parties were, what conflicting public values they purported to advance, and whether the challenged agency position-and therefore delay in resolving the challengehad an effect in terms of those concerns and values. Had the Court been led to inquire into the problem of inspection in the cosmetics industry and the effect of a threat of inspection upon industry planning, it would have discovered that a principal reason for challenge was the enormous importance attributed to the secrecy of cosmetic formulae. This concern was a rock on which industrygovernment negotiation and congressional consideration of comprehensive legislation regulating cosmetics had stalled for years. ${ }^{237}$ The prospect of delay in resolving the threat to secrecy, and of consideration of the issue in a certification proceeding controlled by a poorly advised or unsavory manufacturer, might be expected to move many manufacturers to shift from reliance upon secret formulae, ${ }^{238}$ with consequences for buoyancy and competition in the industry that might or might not be undesirable depending upon the relative weight given particular values by Congress. ${ }^{239}$

organization actually represents any number of interests. In choosing which of them is to be considered relevant to the "case" at the jurisdictional stage, the court makes implicit choices among the several legislated policies that might govern its ultimate disposition. Cf. Ely v. Velde, 321 F. Supp. 1088, $1091-92$ (E.D. Va. 1971). A court might, for instance, consider the effect on the detail-men as a form of technological unemployment resulting from the standardization of drug formulations and the development of quality control devices, and bring statutes designed to ameliorate technological unemployment into play in disposing of the challenge to the agency position. Even if a court chooses to limit itself, on some articulated grounds of policy, to a single statute or set of statutes, the selection of interests to weigh represents a reading of the policy of that statute. That process is explicit in determining the availability of review under the new formulations for standing. Because it is explicit, the incursion into the merits can be limited. If the process were made similarly explicit here, in the determination of hardship, it would probably be seen that the postponement of review for want of "sufficient hardship" is either quite arbitrary, in that the court has not made inquiries relevant to the need for judicial review, or a judgment on the merits, in that it is a determination that particular interests need not be taken into account in judging the legality of a position.

237. See, e.g., Drug Trade News, July 8, 1967, at 18, col. 1; FDC Reports, Oct. 30, 1967; Brief for Toilet Goods Assn. at 18-21, 25. The Court mentions protection of trade secrets only in passing and does not mention formulae at all in discussing inspection. 387 U.S. at 164. The law of trade secrets was not deemed necessarily adequate for purposes of the cosmetic industry by persons involved in the development of new legislation. FDC Reports, June 12, 1967, at 5; id., July 3, 1967, at 5; Drug Trade News, July 3, 1967, at 30, col. 3. See text accompanying note 323 infra. 1964).

238. Cf. Toilet Goods Assn., Inc. v. Celebrezze, 235 F. Supp. 648, 652 (S.D.N.Y.

239. The scope of the inquiry prescribed by this first branch of the ripeness test- 


\section{The Dark Side of the Administrative Process}

Moreover, the administrative process itself can magnify the adverse consequences of withholding review. Enforcement proceedings, in which the agency controls the determination of the grounds for its decision and therefore the issues that can reach the court, are necessarily an elusive vehicle for judicial review. A person who is denied review in a pre-enforcement proceeding in which he may raise the troublesome issue is not remanded to proceedings in which

"the hardship to the parties of withholding court consideration"-has had an effect in the lower federal courts since Toilet Goods $I$. In Continental Oil Co. v. Burns, 317 F. Supp. 194 (D. Del. 1970), a court dismissed a legal challenge to an interpretive rule for want of ripeness because there was no evidence in the record to show that the current operations of the party originating the review proceeding fell within the coverage of the rule, despite the fact that a trade association had come in as amicus.

In Sea-Land Serv., Inc. v. Federal Maritime Commn., 402 F.2d 631 (D.C. Cir. 1968), a court of appeals dismissed for want of jurisdiction a petition to review a "report" of the Maritime Commission which had announced, without reference to any specific tariffs, that a relatively inefficient carrier between two ports might legally charge generally lower tariffs than a modern, faster carrier operating among a number of ports (including the two in question) and that the modern carrier did not have any general right to lower its tariffs between those two ports alone to meet price competition on that route. There was no problem of standing or finality. The agency had itself later characterized findings of the report as "declaratory of the general considerations involved" and "directed to the question of differentials generally," and the court viewed them as "legal conclusions." 402 F.2d at 633-34. Yet the court found that the position was not ripe for review. In doing so the court stayed within the terms of the analysis set out in Abbott and Toilet Goods. It looked at the hardship to the challenging party before it in postponing review, and at the relative desirability of review in the context of a specific rate proposal. The only certain and specific injury that the petitioner could attribute to letting the agency position stand was the automatic four-month suspension of its rate-reducing amendments as a result of the agency's reliance upon its announced position in exercising its discretion to suspend. That loss to the petitioner did not in the court's view outweigh the difficulty of deciding the issue on the record before it, or the possibility of avoiding the necessity of review altogether by postponement if the agency should change or make exceptions to its general position when presented with specific rate-reduction proposals. 402 F.2d at 634.

One need not speculate what further losses the court might have found if it had looked beyond the challenger. The Port of New York Authority had intervened in the case at the administrative level to object on legal grounds to a presumptive difference between the less efficient carrier's rates from the port where it operated and the modern carriers' rates from New York. Although New York was apparently not involved in the appellate jurisdictional litigation, the impact of postponement on that beneficiary of the regulated system was clear. Its tax and revenue policies and its plans to attract shipping and the business that accompanies it would have to take account of a presumption that other ports will enjoy a more favorable rate structure. No independent weight was given to that impact in judging the need for judicial review. In a striking illustration of the operative effects of the model of private litigation embodied in the ripeness test, the court seemed to measure the importance of the favored-port issue by its relative prominence in the challenging party's briefs. (If, in treating the favored-port issue as it did, the court was also responding to a concern that the issue would not be well argued by the parties in control of the litigation, it is evident that the direct review proceeding before it provided the court an opportunity to invite intervention or to search actively for other review proceedings involving the same issue. Similar opportunities would not be presented in an enforcement proceeding.) 
he will have similar opportunities, but to a bout of shadowy boxing. As long as the administrative position has not been explicitly overruled, it may remain the motivating factor for decisions by administrators ostensibly made on other grounds. As a matter of institutional sociology, members of the agency may be more loyal to the principle of legality than to their superiors, and if a court has in fact rejected an institutional position they may have personal difficulties in continuing to apply it. But they may have no such scruples in applying it quietly if it has not been rejected. Institutional loyalty may dominate doubts about the legal propriety of defeating judicial review, or moral doubts about concealing the grounds for decision. Indeed, such doubts may not arise. Preventing access to the courts may be viewed simply as part of the game played with the regulated parties, and justified by ultimate regulatory goals.

The Court has struggled in a variety of contexts with administrative capacity to defeat appeal by concealing the grounds for decision ${ }^{240}$ or even mooting a case that is made a vehicle for review. ${ }^{241}$ It puts in question the fairness and utility of a remand after treatment of the merits in a particular fact situation, and the justification for undertaking to treat the merits nonetheless is that the resolution of the legal issues will have an effect on agency behavior in future cases. ${ }^{242}$ It should, a fortiori, be relevant to the propriety of remand before resolution of the questions raised in a case of direct review. The express purpose of direct review is to affect future cases. After escaping direct review in Toilet Goods $I$, the agency could claim that a manufacturer resisting inspection of his formulae had presented insufficient evidence for certification of his color additive batches. Judicial approval of a denial of certification for which any plausible substantive reason is advanced is an outcome more probable than not in any series of such appeals taken to a busy court. Most courts are loath to overrule "scientific" judgments when public health is involved. ${ }^{243}$ Certification may then be offered if the manufacturer gives out his formula, and the manufacturer,

240. See Citizens To Preserve Overton Park, Inc. v. Volpe, 401 U.S. 402, 416 (1971); Burlington Truck Lines, Inc. v. United States, 371 U.S. 156, 168-69 (1962); SEC v. Chenery Corp., 332 U.S. 194, 210 (1947) (dissenting opinion); United States v. Morgan, 313 U.S. 409, 425 (1941) (Morgan IV) (dissenting opinion).

241. See A.L. Mechling Barge Lines, Inc. v. United States, 368 U.S. 324, 330-31 (1961). Compare Lamont v. Postmaster Gen., 229 F. Supp. 918, 917 (S.D.N.Y. 1964), revd., 381 U.S. 301 (1965), with Heilberg v. Fixa, 236 F. Supp. 405, 407 (N.D. Cal. 1964), affd. sub nom. Lamont v. Postmaster Gen., 381 U.S. 301 (1965).

242. See L. JAFFE, supra note 20, at 589; Jaffe \& Vining, in L. JAFFE, supra note 20, at 716-17.

243. See, e.g., Austern, supra note 60 , at 54 . 
without judicial recourse, has the choice of giving up his product or his secret. Thus, since loss of secrecy is irreversible, the agency may be able to achieve a substantial part of its goal before the issue is squarely put in a certification proceeding.

Even legislative rescue from this dark side of the administrative process is difficult, because the issues involved may never be clearly defined before they are fairly moot. Under the influence of the administrative position the system may in fact change to the point where the vested "interests" of the parties-which by definition lean against necessitated changes in calculations or withdrawal from lines of development in which investment has already begun-are no longer as affected. For example, in the Abbott situation detail-man marketing might decline. Management, its personnel continually changing, may come not to think in terms of such marketing or rely upon it. Certainly "interest" in it may cease to support the effort required to obtain a legislative resolution of the issues. But a change in the interests of the parties would not confirm the wisdom of the court's postponement. The "interests of the system" remain the same, and surely one of the major functions of modern judicial review is to disentangle and clarify meritorious issues of policy which emerge inchoate from the administration of the broad standard announced by Congress, and which, if caught in time, may provide an opportunity for a reassertion of congressional control.

The declaratory action should be seen as a response to that everpresent part of the administrative process where the outcome on the merits is an incidental by-product of a contest of tactics, bluff, and strength. We have already noted that when an agency seeks to change an enforcement proceeding into a direct review proceeding built around a legal issue after a private party has mooted the specific factual context, the Court has found reason to maintain jurisdiction over the "case" in the "public interest in having the legality of the practices settled." 244 It should do no less when a "private"

244. United States v. W.T. Grant Co., 345 U.S. 629, 632 (1958) (" $[$ T] he voluntary cessation of allegedly illegal conduct does not deprive the tribunal of power to hear and determine the case, i.e. does not make the case moot. . . . A controversy may remain to be settled in such circumstances, e.g. a dispute over the legality of the challenged practices. .... The defendant is free to return to his old ways. This, together with a public interest in having the legality of the practices settled, militates against a mootness conclusion."). See Local 74, United Carpenters Union v. NLRB, 341 U.S. 707, 715 (1945) (The mooted case was only "a sample of what might be repeated elsewhere if not prohibited."); Walling v. Helmerich \& Payne, Inc., 323 U.S. 37, $42-49$ (1944); United States v. Trans-Missouri Freight Assn., 166 U.S. 290, 309-10 (1897) (In mooting the facts, "there has been no extinguishment of the rights (whatever they are) of the public, the enforcement of which the Government has endeavored 
institution seeks direct review. The public interest is the same, as the standing cases now make clear. What either side seeks is an authoritative determination that will affect the behavior of all persons active in the regulatory field, and eliminate the necessity of sparring with parties who are evading review while the effects of the challenged positions proliferate.

\section{The Effect of Delay upon the Agency}

The Court in Abbott spoke of evaluating "the hardship to the parties of withholding court consideration" of the issues, and went on to observe that indirect review would delay enforcement and direct review would speed it. ${ }^{245}$ The prescribed inquiry seemed limited by Toilet Goods I to "the immediate severity of the regulation's impact upon the plaintiffs." 246 But surely the effects of an agency position on the agency's own operations, the spreading readjustment of agency attitudes and procedures to take account of the new fixed point and the reallocation of personnel and resources during a period of delayed review, are as important to the achievement of legislated goals as the effect of the position on others active in the field. At least one circuit has sought to take the planning needs of the agency into account in assessing the need for direct review under the rubric of ripeness. ${ }^{247}$ The problem is that the facts are inaccessible. An agency resisting review will not willingly bring forth its planning needs and the impact of the position on its operating decisions, nor indeed analyze them in any careful way. And so long as courts' jurisdiction to review a final administrative position is kept a question open to litigation, the adversary posture into which agencies will necessarily be cast will prevent them from ex-

to procure by a judgment of a court. ... By designating the agreement in question as illegal ... we simply mean to say that such is the character of the agreement as claimed by the Government. ... Whether the agreement is of that character is the question herein to be decided."). See note 109 supra; text accompanying note 300 infra.

245. 387 U.S. at 154-56.

246. 387 U.S. at 170 (emphasis added).

247. [ [] $\mathrm{t}$ is to the advantage of both the importers and the Commission to know now whether the importers will have to live with the rule (and thus alter their contracts accordingly) or whether the Commission should cancel plans to appropriate sums and personnel to implement the rule before a large apparatus is actually set up.

Textile \& Apparel Group, American Importers Assn. v. FTC, 410 F.2d 1052, 1055 (D.C. Cir.), cert. denied, 396 U.S. 910 (1969). See also National Automatic Laundry \& Cleaning Council v. Schultz, 443 F.2d 689, 702 (D.C. Cir. 1971): "[The] 'expected conformity' [to a final agency position] stressed in Abbott . . . embraces conformity not only by the businessman affected but by the agency personnel. ... [P]rompt judicial review will benefit the total administrative process by resolving uncertainties. . .." 
ploring such effects or bringing them to a court's attention. An agency's planning needs and the need for review on that account will no doubt be greater in some situations than in others, but a court will not know which, and neither, in all likelihood, will the agency.

As a result, courts will be forced to presumptions. Judicial choice between alternative factual presumptions should be governed as much by policy as by an estimate of probabilities. A presumption that there is no important adverse effect from delay would cut against review and be difficult to reconcile with the basic presumption in favor of review. The alternative presumption, that there is an effect and a need for review on that account, puts in question the need for a showing of ripeness as an independent jurisdictional prerequisite.

The inquiry proposed by $A b b o t t$ to determine the appropriateness of a declaratory action does not seek the systemic effects of delay and relegation of an issue to enforcement review. It takes no account of the dark side of the administrative process and gives no weight to the important function the declaratory action is designed to serve. Indeed, the ripeness test seems based ultimately upon the tenet that problems which solve themselves are solved best, a tenet at war with the basic premise of the administrative process, that society can choose and control the changes brought about within itself as a result of its organized activity. How different the inquiry into the costs of withholding review when the question is not ripeness but preclusion of direct review. In administering the Labor Acts, the Court has taken pains to satisfy itself that the delay resulting from denial of direct review has been specifically countenanced by Congress and justified as necessary to achieve the goals of the regulatory system. ${ }^{248}$ The difference lies in the conflicting presumptions underlying the doctrine of preclusion and the doctrine of ripeness, one in favor of review, and the other against it. ${ }^{249}$

248. See Boire v. Greyhound Corp., 376 U.S. 473 (1964) (agency position that certain facts produced a "joint employer" relationship held insufficient as a matter of law by trial court, but direct review found precluded); AFL v. NLRB, 308 U.S. 401, 409-12 (1940).

249. One response to the objection that the terms of an inquiry are irrelevant or inadequate to its purpose is to expand the terms. Can this first branch of the ripeness test be usefully recast to require that courts look beyond the costs to the challenging party in determining whether to defer review? There are, as we have noted, important effects of delay that are largely inaccessible to judicial evaluation on a case-by-case basis. But let us put those aside and seek to apply an expanded test to the situations that the Court faced in Abbott and Toilet Goods I. One can argue that the likelihood and extent of systemic change by reason of delay is greater in Abbott where the Court allowed review than in Toilet Goods $I$ where review was deferred. In $A b b o t t$ changes in the habits and thinking of the beneficiaries of the regulatory system 
as well as the regulated parties might have occurred. The difference between direct review and review in a new drug licensing proceeding (see note 215 supra) is not whether prescribing physicians and consumers are exposed for a period of time to the equation of the trade name and the generic name. That is a question for the law of stays (see text accompanying notes 229-32 supra), and a court might require compliance with the "every-time" regulations pending completion of direct review. The difference in enforcement review is the inevitability of exposure (assuming that a stay might be obtained) and the length of exposure. Compliance until the question reaches a court in a new drug proceeding could continue for years, given the number of possible reasons for delaying a decision on a new drug application, such as an asserted need for more data on one or another aspect of safety or effectiveness. A change in market psychology, an evaporation of the associaticns with quality or service built around the trade name, and the beginning of widespread generic-name prescribing might well occur in that time. In contrast, after Toilet Goods I, the attitude of the public toward the secrecy of cosmetic formulae need not be affected at all.

But before one can conclude that delay will produce fewer changes in the Toilet Goods I situation, one must be satisfied that the stocks of certified diluents will hold out while review proceeds through a certification proceeding, and that the agency cannot use publicity about resistance to inspection more effectively during a longer period of delay before resolution of the issue, to substitute for the association between secrecy and romance an association between secrecy and danger. And when one seeks to weigh the extent of the systemic effect of delays, the real question is the degree to which the changes that can be predicted are irreversible. Though the changes in the position and function of trade names may involve the behavior of both the regulated and the beneficiaries, they may be more reversible than changes with respect to cosmetics that involve the behavior of only the manufacturer.

Thus if the ripeness test were preserved but changed to direct that judicial choice between immediate and delayed review be made according to the relative seriousness of the irreversible systemic effects rather than according to the relative seriousness of the hardship to the challenger, the terms of the inquiry would be immensely complex. The question would be immediately raised, What is to be gained by running such judicial comparisons between the operations of different regulatory systems? That is tantamount to the question, What is gained by preserving a judicial choice between direct and enforcement review? We will seek to explore the answer below, pt. VII. B. I. infra. The answer, I believe, is that there is little if any gain to offset the difficulties of making a rational choice.

Moreover, such an inquiry takes a court so far into the merits of the controversy that stopping short of a final decision and declaration may be impossible, in view of the probable reactions of the parties and other courts (see text following note 295 and pt. IX. A. infra). It would, in any event, be highly inefficient. Selecting the systemic effects that would be relevant to the weighing in light of the legislated goals of regulation, and determining how serious and important those effects are for purposes of the weighing, may be viewed as indistinguishable from the process of judicial review. Textile \& Apparel Group, American Importers Assn. v. FTC, 410 F.2d 1052 (D.C. Cir.), cert. denied, 396 U.S. 910 (1969), illustrates the point. In question was an FTC rule (issued under general rule-making authority) setting up a procedure for detention of imported wool at customs pending tests for mislabeling. The rule substituted licensing for policing as the FDA had sought to do in Toilet Goods II. The advantage to the administrative field was the more efficient detection of mislabeled wool. The cost to the petitioning importers was financial. Since bond could be posted and the goods sold before the completion of the tests, they were being asked essentially to pay an insurance premium against the possibility of mislabeling. Any other cost would be a result of their refusal or inability to pay that premium. The court found the issues before it ripe for decision and proceeded in the same opinion to rule in favor of the challenge on the merits. What is intriguing about the case is that for purposes of evaluating the need for review the court looked beyond the impact on the petitioners of denial of review and, assuming that they might refuse to pay the premium, traced out the effects on the pattern of commerce in woolens produced by the possibility of physical detention of imported goods at customs. Relying on "uncontradicted affidavits from wool importers that delivery of style woolen goods, such as sweaters, is a highly 


\section{Choice of Litigation by Individuals}

We have explored some of the possible disadvantages of enforcement review proceedings in connection with their impact upon the behavior of both agency and affected persons during a period of delayed review. ${ }^{250}$ There are, in addition, disadvantages to enforcement proceedings that should bear upon a court's choice even if, as in Storer, the opportunities for enforcement and "pre-enforcement"

volatile business; styles change rapidly, and demands for goods must be met immediately," the court concluded that "[t] the possibility that the imported goods may not be delivered on time, would shift to domestic orders." 410 F.2d at 1054.

The effect discerned, which might or might not be desirable in light of legislated policies, cannot be resolved into indirect "harm" to the challengers, for if this case were viewed and cast into the mold of private litigation the challenging parties might be viewed as estopped to complain of harm that they willfully or negligently caused themselves. It is unlikely that importers would be unable to pay an insurance premium unless the likelihood of mislabeling was very high, in which case the need for universal inspection through licensing might well outweigh adverse effects on competition. Much more likely is that some importers might irrationally refuse to post bond, and that large stores might irrationally conclude that all importers might refuse to post bond. The harm the importers could properly argue was the cost of paper work, interest on short-term money for bonds, and the premium for insurance against the possibility of loss of the bond. Assuming those costs between the direct review proceeding and an "enforcement" proceeding might affect their profits, but not their capacity to compete. Such costs may be viewed as ordinary costs of litigation very much like the costs of a bond imposed on the beneficiary of the status quo pending completion of judicial review of stayed agency action that would change the status quo. See Jaffe \& Vining, in L. JAFFE, supra note 20, at 701. They would not be the reason for a perhaps irreversible movement of large stores away from reliance on imported goods. That effect would stem from the existence of the administrative position itself, and in deciding to take such an effect into account in the jurisdictional proceeding, the court moved away from measuring the need for judicial review according to the challenger's interim losses if he should ultimately prove correct on the merits, and toward reframing the ripeness doctrine in light of the public function of judicial review that now underlies other jurisdictional tests, from "finality" to "standing."

But before choosing even to inquire into the effect of the Commission position on the buying practices of large stores, the court had to have a sense of what values the regulatory system was meant to promote and protect. The petitioners might have brought out or the court might have looked for and found an infinite number of probable effects upon commerce in woolen goods flowing from the adoption of the position. When the court selected and made relevant to its decision one of those effects, the impact on large stores, there was an implicit determination that competition or the availability to individuals of the widest possible variety of wearing apparel were legislated goals as well as the elimination of deception. This is virtually identical to what is involved in applying current doctrines of standing. When the court went further and sought under the rubric of ripeness to weigh this effect in determining the need for review, it began to measure the degree to which the effect promotes or retards the discerned values and the relative weight to be accorded those values. That process dissolves into a consideration of the merits. In concluding that there was a need for review, as it did, the court had gone far toward a conclusion that there was a need for a judicial remedy.

250. By disadvantages, we mean those relevant to the public function of judicial review. It is not useful to measure disadvantage from the perspective of either agency or challenger. 
review are simultaneous. In enforcement proceedings, administrative or judicial, individuals are in jeopardy. When licensing is required, as is so often the case, an agency may threaten to engineer adverse publicity that will put the individual at a competitive disadvantage or to withhold or delay other important rulings or approvals on which the efficiency and success of the individual depend, if he seeks to use a licensing proceeding to challenge an agency position. This may distort review at any point in its course, in the sense that the arguments made on the merits, and the force with which they are made, will vary with vulnerability to agency pressure. It may indeed eliminate review entirely. Pre-enforcement review, on the other hand, is often initiated by associations or is in a form in which large numbers of interested parties may intervene; and in numbers there is comparative safety..$^{251}$

\section{Choice Among Individual Litigants}

We have also mentioned the distortions that are inherent in any proceeding in which the treatment of general issues is dictated by whether they advance or avoid a particular result. ${ }^{252}$ These distortions are particularly severe in an administrative context where litigated cases are not, as at common law, sparks thrown up from creative social tumult. Administrative litigation is often centrally controlled and planned, ${ }^{253}$ and when a court chooses between pre-enforcement and enforcement review, it is really choosing between a proceeding initiated by the challenger and one initiated by the agency. ${ }^{254}$ If a court chooses enforcement review, it is allowing the agency to choose both its own opponent and a factual context that will color ${ }^{255}$ consideration of the issues in favor of the agency position.

The choice of opponent is a matter of obvious concern. It is not the strong and well-advised industry member, who perhaps parti-

251. It is no doubt true, however, that associations give priorities to the resolution of particular issues, and their litigating strategy may be distorted by negotiations between the association and the agency on substantively unrelated issues.

252. See note 278 infra; text accompanying notes 20-21 \& 217 supra.

253. See $1 \mathrm{~K}$. Davrs, supra note $50, \S 4.07$, at $255-61 ; 3$ id., $\$ \S 19.01-.07$, at $1-46$ (1958).

254. Licensing proceedings, which are inevitable and through which all potential challengers must pass, may be thought an exception. The agency often does not initiate, and the first party to face the position must challenge it or set an adverse precedent, or, worse, bind himself without binding others. The parties may thus be chosen by chance. But the agency may initiate proceedings to de-license and time the announcement of a position so that it is certain to be tested in a particular proceeding. The agency may even announce it in connection with the proceeding.

255. This is rather different from the avoidance of effective judicial review by advancing overlapping reasons for administrative action. 
cipated in the evolution of the governing legislative standard, who is first prosecuted. It is the marginal firm that is called upon to illuminate the public values that the agency position may contravene. If there is intervention, the object of the proceeding is still the central and managing litigant, and a point of great general importance may become res judicata by default.

The power to choose a particular factual setting for the testto choose the terrain as well as the opponent-cannot be taken lightly either. The degree to which the equities of a case can determine its outcome and tend to make the disposition of even general issues result-oriented is well known. Coloring goes further than the arousal of sympathy, and further than serving the perhaps legitimate educative function of illustrating the general justifications for a rule by a vivid and extreme example. It can be used to achieve intellectual confusion, in which, partly because of the logic of a "case," the demonstrated evil assumes an exaggerated significance to the disposition of the challenge to the position, and is not viewed merely as one unit in a calculus of averted dangers, irrational outcomes, and administrative practicalities that might justify a per se rule. ${ }^{256}$

Intellectual confusion can also result when questions of coverage are involved. The general issue may be casually handled or even lost if there is doubt about the applicability of a position to the particular fact situation or individual presented. By contrast, in pre-enforcement review the determination of the precise meaning and reach of the position is not necessarily linked to consideration of its merits. The immediate factual setting is unimportant and the attention of parties and court can turn to the range of factual situations on which the position, if established, has an impact. And in such a proceeding where numbers of interested parties may participate on a more or less equal basis, the likelihood that ramifications will be fully explored and relevant considerations intelligently briefed and fully presented is greatly enhanced, and with it the likelihood that the court's resolution of the issue will be rational and sophisticated. ${ }^{257}$

256. See FTC v. Colgate-Palmolive Co., 380 U.S. 374 (1965) (announcement of a rule banning the use of mock-ups in television advertising in a case in which the mock-up had in fact been used to convey a false claim about the performance of the product); Shapiro, The Choice of Rulemaking or Adjudication in the Development of Administrative Policy, 78 HARv. L. REv. 921, 937-40 (1965). Compare The Supreme Court 1964 Term, 79 HARv. L. REv. 56, 189 (1965); United States v. Philadelphia Natl. Bank, 374 U.S. 321, 362-63 (1963).

257. A proceeding that disposes of an issue early and binds a large number of affected parties also conserves judicial resources far more than the postponement of review to an enforcement proceeding. See Abbott, 387 U.S. at 154; National Automatic 
Indeed, when a trade association like the Toilet Goods Association, or a class collected under Rule 23,258 seeks to challenge a position with special counsel, sources of information and litigating resources, and freedom from the internal and external constraints felt by its members individually, it is difficult to see how a court can postpone review to an enforcement proceeding without thereby approving the denial of all review to the party before it. ${ }^{250}$ At least since $C B S$, the Court has recognized that a contingent opportunity to intervene is not a substitute for review.

\section{Civil Disobedience}

A final possible cost may be briefly mentioned. Many have doubts today about the legitimacy of civil disobedience, whatever its motivation. ${ }^{260}$ Since inviting an enforcement proceeding for the purpose of resolving legal issues is a form of civil disobedience, persons entertaining such doubts may argue, indeed should argue, that judicial doctrines which push prominent institutions to enforcement review are inappropriate to current conditions. The habit of respect for authority may be thought too weak and the legal order too unstable to withstand the spectacle of such planned defiance.

\section{B. Defects in the Calculation of Gains}

With these costs and inherent disadvantages in mind, we may ask what the Court thought was to be gained by choosing enforcement review in Toilet Goods I. The Court grounded its choice on the relative "appropriateness" of the legal issues for resolution "in the framework of a generalized challenge" and "in the context of a specific application." 261 We move, therefore, from the evaluation of costs to the second branch of the ripeness test, the prediction of gains to be secured by choosing enforcement review.

Laundry \& Cleaning Council v. Schultz, 443 F.2d 689, 704 (D.C. Cir. 1971). It may also be discovered in reviewing an enforcement proceeding that the general issue need not be reached because the rule or announced position does not cover the individual or fact situation presented, with consequent waste of the resources, both parties' and courts', that would be consumed in its litigation.

258. Fed. R. Crv. P. 23.

259. "Only in rare circumstances will a litigant in one cause be compelled to stand aside while a litigant in another settles the rule of law that will define the rights of both." Landis v. North America Co., 299 U.S. 248, 255 (1936). Cf. Leedom v. Kyne, 358 U.S. 184, 190 (1958).

260. See President's Commission on the Causes and Prevention of Violence, RePORT 92 (1969). Cf. note 129 supra; Walker v. City of Birmingham, 388 U.S. 307, 321 (opinion of the court), 327 (dissenting opinion) (1967); Glay v. United States, 397 F.2d 901, 905, 913 (5th Cir. 1968), revd., 39 U.S.L.W. 4873 (U.S. June 28, 1971).

261. 387 U.S. at $163-64$. 


\section{1. "Finality"}

The first factor mentioned by the Court in connection with the determination of relative appropriateness may be put aside with some confidence. The Court said it had "no idea whether or when ... an inspection will be ordered." 262 This is a resurrection of the doctrine that agency action is not "final" if the agency must take further discretionary steps before a party suffers a sanction, a doctrine that has been abandoned in administrative law at least since $C B S$ and Storer and was in fact rejected in Abbott. ${ }^{263}$ It reflects a premise of common-law "jurisdiction"-that courts must have the last word, mold reality as well as the law-which has no place in administrative law. Courts do not and should not always have the last word in the administrative process. ${ }^{264}$

"Finality" in this sense and "ripeness" have an obvious similarity of connotation. What has ripened has taken its final form, and the terms have been used as synonyms. ${ }^{205}$ As the considerations of judicial economy, judicial mystique, and laissez-faire which underlay this requirement that there be repose after a court speaks fell away in administrative law, the meaning of "finality" contracted. ${ }^{266} \mathrm{But}$ instead of dying with its synonym, "ripeness" has remained in the

262. 387 U.S. at 163 .

263. See text accompanying notes 71-74, 97-99, 162 \& 216 supra. Cf. Justice Frankfurter, dissenting, in $C B S$ :

Consistently with regulations (and, parenthetically, consistently with the authority of the Commission to depart from general regulations where such departure is in the public interest ...), the Commission is free to dilute them with amendments and exceptions. The construction of the regulations and their application to particular situations is still in the hands of the Commission. Administrative adjudication is still open. Before its completion it is not ripe for judicial review.

316 U.S. at 433.

Giving weight to the fact that an agency may approve ad hoc exceptions or redefine the scope of a general rule is no different from giving weight to the possibility that an agency may not carry out its announced intent. In holding direct review unnecessary the lower court in Abbott relied upon statutory provisions for exemption from the requirement that generic names appear "prominently." Abbott Laboratories v. Celebrezze, 352 F.2d 286, 289 (5th Cir. 1965). The Supreme Court reversed without adverting to the possibility of exemptions. Their irrevelance should be clear once courts recognize that efficiency can no longer be defined as the avoidance of review whenever possible. Adding a provision for exemptions simply transforms the announced position into a presumption. The provision is no less crystallized. It will be relied upon as such by the agency in the disposition of particular cases and the excrcise of discretion. It must be taken into account in the planning of all those active in the field. In fact, a presumption may produce more uncertainty than an absolute rule, and thus a greater demand for review. But see Sea-Land Serv., Inc. v. Federal Maritime Commn., 402 F.2d 631, 634 (D.C. Cir. 1968).

264. See note 322 infra; text following note 299 infra.

265. See Collins v. Miller, 252 U.S. 364, 371 (1920); Aquavella v. Richardson, 437 F.2d 397, 403 (2d Cir. 1971).

266. See Port of Boston Marine Terminal Assn. v. Rederiaktiebolaget Transatlantic, 400 U.S. 62, 71 (1970); text accompanying notes 22 \& 216 supra; text accompanying notes 236-37 infra. 
legal vocabulary to convey the dead idea. Perhaps it is that judicial changes in doctrine must proceed by changes in the meaning of constant terms, ${ }^{267}$ and ripeness could not undergo the necessary contraction without disappearing altogether. If so, there may have to be a legislative execution. But the legislative effort to kill a ghost seems so unnecessary. Unlike "finality," "order" or "proceeding," the term "ripeness" does not have statutory status, and the Court is not therefore constitutionally bound to find work for it to do. If it can be concluded that no residual flexibility would be lost-a question we will explore below ${ }^{288}$ — the Court should be able to take the step.

\section{Illumination of the Issues}

The second factor mentioned by the Court in Toilet Goods $I$ is that the legal authority asserted for the regulation was authority to promulgate regulations "for the efficient enforcement of [the Act]," and that the Court must therefore inquire "whether the statutory scheme as a whole" justified the regulation. ${ }^{270}$ The relevance of this observation to the choice of a declaratory or enforcement proceeding as the vehicle for review is not self-evident. In the first place, the regulation is no more than an announcement of an agency position that refusal to be inspected would be considered by the agency sufficient ground for denying certification. Authority to announce such a position in advance of applying it in a certification proceeding need not be found in the empty phrase "for the efficient enforcement of the Act" included in the agency's organic statute. It can be found, if indeed any authorization is necessary, in the APA, ${ }^{271}$ and as we have noted, ${ }^{272}$ agency positions of this kind can appear in speeches, letters, and opinions as well as in the form of a rule. Nothing new therefore is added by the source of authority alleged. Moreover, the regulations in Abbott and Toilet Goods II, for which a declaratory proceeding was held appropriate, were also promulgated "for the efficient enforcement of the Act."

In the second place, the necessity of looking to "the statutory scheme as a whole" would seem to cut in favor of a "generalized challenge." The Court elaborated what it believed to be relevant to a

267. See generally L. FuldER, LEGAL FICTIONs (1967).

268. See pt. X. infra.

269. Federal Food, Drug and Cosmetic Act § 701(a), 21 U.S.C. \$ 371(a) (1964).

270. 387 U.S. at 163.

271. E.g., APA $\S$ 2(c), 4(a), 4(d), 12, 5 U.S.C. $\$ \S 551(4)-(5), 553(b)(1), 553($ c), 559 (Supp. V, 1965-1969).

272. See text preceding note 12 supra. 
determination that the "statutory scheme as a whole" justified the position-an understanding of the types of enforcement problems under the act, the need for "various sorts of supervision" (by which the Court must mean, inter alia, inspection at the beginning as well as licensing at the end), and the safeguards devised to protect "legitimate trade secrets." 273 Earlier the Court had remarked that it would want to know what "reasons the Commissioner will give to justify his [inspection] order."274 The Court then seemed to say that such information and understanding can be obtained better in an enforcement proceeding than in a declaratory proceeding. ${ }^{275}$

But that conclusion does not follow. There is no reason to believe that any such information will be forthcoming in the enforcement proceeding to which the Court relegates the issue. The proceeding will look not to an inspection order, but to an order granting or denying certification to a batch of color additives. The agency position is that the only evidence which need be adduced to support an order denying certification is evidence that the petitioner denied an inspector free access to formulae. Any account of the range of enforcement problems under the act, the protections that the agency can provide (but does not assure in the regulation), and the need for inspection to advance the goals of the act will come by way of briefs. ${ }^{276}$ Such briefs are much more likely to be written, and written well, in connection with a declaratory proceeding focusing on inspection than an enforcement proceeding focusing on

273. 387 U.S, at 164.

274. 387 U.S. at 168 .

275. At the end of the opinion the Court asserts that in an enforcement proceeding "the factual basis of the inspection order will certainly be aired and ... more light may be thrown on the Commissioner's statutory and practical justifications for the regulation." 387 U.S. at 166.

276. See, e.g., Aquavella v. Richardson, 437 F.2d 397, 404 (2d Cir. 1971). The practice suggests that "questions of law" are actually reviewed upon a form of "record." Indeed, a "hearing" on legislative intent took place on remand in Toilet Goods II. 278 F. Supp. 786 (S.D.N.Y. 1968).

In any event, courts are not confined to a choice between proceeding on briefs and affidavits on the one hand, and postponing and transferring review to an enforcement setting on the other. Courts have been increasingly willing to call for the making of an administrative or judicial record in a direct review proceeding where a record appears necessary to resolution of the issues. Citizens To Preserve Overton Park, Inc. v. Volpe, 401 U.S. 402 (1971); Environmental Defense Fund v. Haxdin, 428 F.2d 1093 (D.C. Cir. 1970); Industrial Union Dept. v. Barber-Coleman Co., 348 F.2d 787 (D.C. Cir. 1965). In Barber-Coleman, however, Chief Justice, then Judge, Burger dissented and urged that the agency position (that more than one minimum wage could be set for an industry under the Walsh-Healy $A c t$ ) could and should have been reviewed as such without the burden and delay of a remand for fact-finding with respect to its applicability in a particular industry. $348 \mathrm{~F} .2 \mathrm{~d}$ at 790. 
denial of certification, in which the agency may well advance additional reasons for denying certification. ${ }^{277}$

Quite aside from raising questions about the appropriateness and juridical effect of a court's determination of the legality of the agency's position on inspection if the court should find other grounds sufficient for a denial of certification, ${ }^{278}$ the presence of other substantial grounds, perhaps relating to demonstrated dangers to the public health in the uncertified additives, affects the care with which the court is likely to consider arguments about the legal relevance of resisting inspection. Litigants making such arguments in such circumstances would ordinarily be viewed as grasping after technicalities. If the danger of an additive is demonstrated, resistance to inspection of the formula would seem obviously relevant;

277. The Court in Toilet Goods $I$ mentioned the further objection that enforcement proceedings at the administrative level will not contribute to a clarification or elaboration of what may be called strictly legal arguments, for example, those drawn from legislative history or prior case law. But in a curious and perhaps revealing departure from its purported balancing of costs and gains, the Court declined even to explore the argument, "given the fact that only minimal, if any, adverse consequences will face petitioners" in enforcement review. 387 U.S. at 165-66. In fact the objection seems sound, not only with respect to Food and Drug practice but generally. The agency has announced its legal position, and need not argue it again to itself. Another ruling by the agency that it has the challenged authority adds nothing and, recognizing this, agencies often do not allow "Iegal" arguments at the administrative level if they relate to a position already taken. In this respect relegation of a legal issue to an enforcement proceeding allows at most reconsideration of the position and the chance of eliminating the dispute. But even the APA does not require reconsideration before a position is deemed "final" enough to warrant consumption of judicial resources. See APA \& 10(c), 5 U.S.C. \& 704 (Supp. V, 1965-1969).

278. See $\S 10($ e) of the APA, 5 U.S.C. \& 706 (Supp. V, 1965-1969):

Scope of Review. To the extent necessary to decision and when presented, the reviewing court shall decide all relevant questions of law, interpret constitutional and statutory provisions, and determine the meaning and applicability of the terms of an agency action. ... and due account shall be taken of the rule of prejudicial error. (Emphasis added.)

The "decision" to which the APA refers is disposition of the "case." Questions of law are "relevant" if relevant to the "case." The "error" that may be ignored as not "prejudicial" is error that would not affect the outcome of the "case." Therefore if the "case" is not built around the challenge to the agency position as such there is no guarantee that the challenge will be faced. C $f$. Willapoint Oysters, Inc. v. Ewing, 174 F.2d 676, 691 (9th Cir.), cert. denied, 338 U.S. 860 (1949).

The question of remand or affirmance when a court does determine that some grounds advanced by the agency are irrelevant, but that other relevant grounds are sufficient, is a complex one. See NLRB v. Donnelly Garment Co., 380 U.S. 219 (1947); State Comp. Commn. v. United States, 184 F. Supp. 691, 700 (D. Kan. 1959) (dissenting opinion). The decision may be thought to ride on whether the standard applied is "substantial evidence" and the factor involved is simply inadmissible "evidence" present in a record that clearly meets the "substantial evidence" test, or whether the standard is that applied to the exercise of discretion, which may be legally defective as much if a legally irrelevant factor is taken into account as if a legally relevant factor is ignored. Certainly a case in which the denial of certification is affirmed with an advisory dictum on the resistance to inspection is an inadequate resolution of the challenge to the agency position. 
the fact that such resistance stems from a general concern for secrecy and the absence of safeguards for secrecy would be lost. In subsequent cases the agency would rely on increasingly marginal evidence of danger to the point where judicial approval of the relevance of resistance is so sealed in precedent that the issue is most unlikely to be considered de novo and with full attention. Thereafter the agency could assert resistance as the principal or only ground for denial of certification, and present a manufacturer with a choice between inspection and decertification without much fear of challenge. The process would be a Pavlovian one, associating in the judicial mind danger and resistance through a careful selection of cases, until resistance alone appears to be sufficient to evoke the response appropriate only for danger. The judicial mind has fixed points as much as the administrative field. It is a living thing only at its edges. The crush of time and complexity of affairs renders inevitable an accretion of structure, set in successive opinions. Individual judges and lawyers are sensitive to it, and though not imprisoned by it, they are aware of the large investment of time and imagination and the small likelihood of success in any attempt to rejuvenate an old question. An inherent defect in enforcement proceedings as a vehicle for judicial review is the strong likelihood of distortion in the growth of this structure.

Moreover, if the criterion of "appropriateness" is really how likely it is that an understanding of the range of topics which the Court requires for decision will emerge from a proceeding, then the fact that a single litigant replaces a trade association when review is shifted from a pre-enforcement to an enforcement proceeding should weigh heavily against the "appropriatenesss" of the enforcement proceeding. The single litigant, as we have noted, ${ }^{279}$ cannot be expected to have the access to information or the litigating resources to match the agency-if the agency should choose to address itself to the relevant considerations of policy-and aid the court in achieving the understanding to which the adversary process is meant to contribute. ${ }^{280}$

There is a further problem in the Court's choice, which goes to its rationality as well as its wisdom. The Court assumed that the "legal issues" would be the same in the enforcement proceeding as

279. See text accompanying notes 256-59 supra.

280. The criticism of the record that was held inadequate for a declaratory judgment on issues of public interest in Public Affairs Associates, Inc. v. Rickover, 369 U.S. 111, 113-14 (1962)-the absence of the views of affected parties, the lack of exploration of administrative practice-might be made generally of the records created for the review of administrative positions in enforcement review. 
in the direct review proceeding before it. Unless the issues are the same, there is no common basis for comparison of the relative "appropriateness" of the two proceedings for their consideration. But the assumption may not be warranted in Toilet Goods I. The legal standard governing the contemplated enforcement proceeding is not likely to be the "efficient enforcement of the Act" or the "statutory scheme as a whole," but rather the specific standard governing certification under section 706(c) of the Food, Drug and Cosmetic Act. ${ }^{281}$ Although there may be debate about just what those specific standards are, ${ }^{282}$ the terms of reference will certainly be whether denial of certification for resisting inspection promotes the purposes of certification rather than whether inspection promotes the purposes of the Act. This is the inevitable effect of the absence of any direct authorization for proposed agency action: However helpful and efficient inspection may be, the sanction borrowed to enforce inspection must advance the purposes for which the sanction was designed if its use is to be legally justified, and those purposes may have nothing to do with the purposes of inspection except in the most general and meaningless sense of promoting public health. A court presented with appropriate arguments might well hold that certification, a process of which the public, not the manufacturer, is meant to be the primary beneficiary, may not be stopped for the purpose of advancing some ulterior agency goal in its political and strategic conflicts with the industry. ${ }^{283}$ Denial of certification to discipline the manufacturer could be viewed as denial to the public of the safe colored cosmetics in which it has a strong interest or as exposing the public to an increased danger that the certification process itself will be evaded and colors that could not pass the final safety screening will be sent to the market.

An assumption that issues are constants is, in any event, a dangerous one. ${ }^{284}$ Certainly no judicial doctrine should be constructed upon

281. 21 U.S.C. $\S 376(\mathrm{c})$ (1964).

282. Under $\S 706$ (c) of the Food, Drug and Cosmetic Act, 21 U.S.C. $\S 376(c)$ (1964), the agency is required to certify additives that are listed and conform to requirements for such additives established by authorized regulations.

283. It is unlikely that the agency could make a case that assurance of safety was impossible without formula inspection, particularly in view of prior congressional omission of such inspection rights. See 21 U.S.C. \$ 374(a) (1964).

284. The importance and difficulty of keeping the issues constant in making the comparison required by the second branch of the ripeness test is illustrated by SeaLand Serv., Inc. v. Federal Maritime Commn., 402 F.2d 631 (D.C. Cir. 1968), discussed in note 239 supra. The agency had issued a "report" that announced, without reference to any specific tariffs, that a relatively inefficient carrier between two ports might legally charge generally lower tariffs than a modern, faster carrier operating 
it. One can expect that after the merits are reached and during the course of appellate litigation the issues will be not merely refined but reformulated or changed, and that what was thought unimportant will become crucial-as study of the history of important litigations should show. Encouraging such change, or the emergence of issues, may be viewed as the purpose of multilevel litigation. The purpose of that costly institution is certainly not mere reconsideration of the same issues by different men. And such change dissolves the basis for the comparison on which the choice between proceedings was made and makes the choice essentially arbitrary.

Of course, by the same token the legal standard in the direct proceeding (if the court had accepted jurisdiction) might have emerged as the same as that which we have suggested would govern the enforcement proceeding. The issue would become whether denial of certification is an appropriate sanction for resistance to

among a number of ports (including the two in question) and that the modern carrier did not have any general right to lower its tariffs between those two ports alone to meet price competition on that route. The agency had itself later characterized the findings of the report as "declaratory of the general considerations involved" and "directed to the question of differentials generally," and the court viewed them as "Iegal conclusions." In the early part of its opinion the court perceived the issue as whether the less efficient carrier was "entitled to a rate advantage." 402 F.2d at 633 . Since there was the possibility of exceptions for specific rates, the question presented was whether it was inconsistent with the statutory intent for the agency to erect and act upon a presumption in favor of a rate differential; and the court recognized that such a presumption was operative and that it had been challenged as such on legal grounds when it referred to the temporary and "discretionary" suspension of rate amendments by the agency in reliance solely on that presumption. But when the court came to justify its choice of indirect proceedings for resolution of the issue, the issue was no longer the legality of the presumption. It had become instead where "to define the bounds of reasonableness in rate divergences." The change was critical. Questions of degree are difficult if not impossible to discuss without reference to particular facts, and a proceeding which provides a "specific rate focus" (402 F.2d at 634) and a detailed factual record has obvious advantages. Those advantages disappear where the issue is whether there is to be a presumptive rate differential. The resolution of that question may in fact not be aided by a focus on a specific rate problem that might divert attention from more general statutory economic and statistical evidence. The agency had found it possible to decide that question on the record before the court. Indeed, before the opportunity arose to avoid review through the doctrine of ripeness, the agency had recognized that an enforcement proceeding would present a different issue. The examiner's opinion had concluded: "TMT [the less efficient carrier] is entitled to a differential. The extent of the differential is not presented here. Had it been an issue, it could not have been determined on this record." 402 F.2d at 634 n.5.

To be sure, a court may be reluctant to allow an agency to give full weight to a presumption, and therefore may demand specific contexts to determine how much weight an agency may properly give a presumption on its discretionary balancing of legally relevant factors. But in Sea-Land the court was being asked whether the agency may set up the presumption in the first place, that is, give any weight to it in making decisions. Only if the answer to that question is "yes" is there any reason to ask "how much?" If the answer is "no" or "not now," there would be no necessity for further questions. 
inspection. But that development would not ex post facto make the Court's comparison and choice in Toilet Goods $I$ rational, for it would render inadequate, if not irrelevant, the list of decisional factors against which the Court measured the degree to which the case before it could contribute to a reasoned resolution of the challenge.

These defects are not a result of faulty analysis in these cases, or poor briefing. These are defects which flow from a test that requires legal issues to be formulated before the merits are reached and that assumes that legal issues are frozen, as by the ancient forms of action, in the shape in which they are first perceived. The ripeness test, in short, requires a court to do what it is not equipped to do, and, more important, should not do: to determine what is significant and what is not significant at the beginning rather than at the end of a case, before argument rather than after. The Court's warning to itself, that "the petitioners appear to suggest" certain factors as relevant to a decision on the merits, ${ }^{285}$ went unheeded, and the Court proceeded without learning what the petitioners actually meant and without receiving from the agency an exhaustive account of what it deemed relevant to a decision on the merits. ${ }^{286}$

\section{The Appearance of Chotce: The Rupeness Decision as a Judgment on the Merits}

\section{A. Categorization of a Rule}

Furthermore, there is reason to believe that a court actually does make a decision on the merits when it purports to choose the context in which the decision will be made. In Toilet Goods I, for example, the Court twice mentions its desire to know what "reasons the Commissioner will give to justify his [inspection] order,"287 and the "factual basis of the inspection order."288 But an enforcement proceeding adds little to the information available to a court, beyond an additional illustration that could as well be traced out in briefs. It is, of course, a mark of intellectual modesty to want to see how something actually works before passing judgment on it, and to be skeptical of one's capacity to imagine its complex operations. But a single illustration, however viewed, is still only a single illustration;

285. 387 U.S. at 158.

286. Had the agency produced such a comprehensive treatment of the relevant considerations rather than made a virtue of what it had not brought out, there would have been little reason not to go ahead. The merits would already have been reached.

287. 387 U.S. at 163.

288. 387 U.S. at 166 . 
the important general considerations and range of systemic effects remain to be demonstrated in briefs. And, as we have pointed out, ${ }^{289}$ requiring review to proceed through enforcement proceedings puts courts at a great disadvantage in acquiring undistorted information and perceiving systemic effects, if they are in fact seeking to judge the legality of the agency position as such. The opportunity to learn the reasons and factual basis for a particular application changes this balance of considerations to an insignificant degree.

But if the Court is not in fact seeking the most suitable vehicle to judge the legality of the position as such, and is saying instead that the legality of the position depends upon how it is administered, then the reasons for a particular application are far from insignificant. They become crucial. The considerations that should guide the choice of a vehicle for the decision on the merits become irrelevant because that decision has in a sense already been made. To say that a rule may be justified by the reasons given in a particular case, to say that those reasons can in themselves be determinative of a court's judgment, is to say that the rule as such is within the authority of the agency and that the existence of the position in the regulatory field, conveying a message as it stands, unqualified, does not contravene the regulatory goals. ${ }^{290}$

If this is what a court is saying when it chooses enforcement review, we may be sure that it does not reflect the adoption of the view, suggested by Justice Fortas in his dissent, ${ }^{291}$ that a rule is nothing more than the sum of its applications and that judgment of its legality must turn upon how it is enforced. Although conforming to early theories of the judicial process and its function within the legal order, such a position would be too radical a departure from the teaching of cases, such as Frozen Food and CBS, which have long recognized the impact of the very crystallization of agency positions. A rule is now more than an outline of its established edges, in legal conception as well as in fact. The possibility of limiting the role of legal institutions to the gradual picking out of the edges of rules in ad hoc dispute solving passed with the day when individ-

289. See pt. VII. B. 2. supra.

290. Cf. Village of Euclid v. Ambler Realty Co., 272 U.S. 365, 395-97 (1926) (existence of zoning ordinance excluding business establishments challenged as unconstitutionally impairing land values and curtailing market opportunities. The Court reviewed and sustained the ordinance "in its general scope and dominant features," but reserved for decision in particular cases "provisions of a minor character, or relating to matters of administration, or not shown to contribute to the injury complained of, which, if attacked separately, might not withstand the test of constitutionality.")

291. See, e.g., 387 U.S. at 199-201. 
uals were largely unexposed to the constraints of law and never subject to the continuous and centrally organized application of power through law. ${ }^{292}$ Red Lion explicitly reasserted the capacity of the Court-and the judicial process-to evaluate agency positions as such, without succumbing to a parade of imaginary horribles that the defending agency might be too inarticulate to counter. ${ }^{208}$ And of course Abbott and Toilet Goods II bespeak a willingness to judge and reject an agency position on its face. The court therefore selects where it determines that the facts of a particular case are crucial to the evaluation of an agency position, and that selection categorizes the regulation with finality. ${ }^{294}$

292. This is not to suggest that individuals were not exposed to constraints and subject to power before the growth of the administrative process, and indeed to constraints and power ultimately approved by courts. The forms of law and appeals to legality were not, however, widely employed in social organization, and the rules themselves, stable and hidden, rarely came to the notice of either courts or individuals who felt their central effects. The growth of consciously directed institutions has thrust the rule to the fore. See text preceding note 21 supra.

293. See 395 U.S. at 395-96:

[J]udging the validity of the regulations on their face as they are presented here, we cannot conclude that the FCC has been left a free hand to vindicate its own idiosyncratic conception of the public interest or of the requirements of free speech. ... We need not approve every aspect of the fairness doctrine to decide these cases, and we will not now pass upon the constitutionality of these regulations by envisioning the most extreme application conceivable. ... [W] do hold that Congress and the Commission do not violate the First Amendment when they require a radio or television station to give reply time to answer personal attacks and political editorials.

294. After referring to the scope of review appropriate to the challenge, the Court remarked in Abbott:

It is suggested that the justification for this rule might vary with different circumstances .... This of course is true, but the suggestion overlooks the fact that both sides have approached this case as one purely of congressional intent, and that the Government made no effort to justify the regulation in factual terms. 387 U.S. at 149. This might be thought to imply that, to defeat pre-enforcement review, the agency need only disagree with the challenger that the issues are legal in character, and that the court does not itself categorize, but rather accepts the categorization proposed by the agency inasmuch as the challenger must always take the position that the issues he raises are "questions of law."

But such a construction of the opinion is impossible. A court is never bound by the opinion of a respondent in evaluating the character of the issues framed by a plaintiff, even where the respondent is an agency. In Toilet Goods $I$, it was clear that the Court determined for itself that the issue as framed by the plaintiff presented a "purely legal question" without reference to the assent of the agency. 387 U.S. at 168. It then proceeded to choose enforcement review nonetheless. What we have here, therefore, is a categorization of the regulation made after and without regard to the categorization of the issues. The Court's remark is merely a quick disposition of the general position adopted by Justice Fortas in his dissent. 387 U.S. at 174. Moreover, if the agency had made an effort to "justify the regulation in factual terms," that fact would seem to cut in favor of immediate review, or ripeness, rather than against it. The court would have the materials for decision at hand.

In any event, the agency always takes the position that a regulation may be justified "in factual terms" when it argues in favor of enforcement review and asserts that the issues are not presently ripe. Indeed the FDA did so in Abbott. See Brief for the United States at 51, 387 U.S. 136 (1967). 
Consider the substantive implications that flow from this ostensibly jurisdictional decision. In $A b b o t t$, the Court announces that the generic-name-every-time regulation, written as it is, may be overturned without regard to whether it is enforced only with respect to labels of drugs whose brand-name price is hundreds of per cent more than the price of the generic equivalent. This decision should rationally reflect a conclusion either that the requirement of the generic name "every time" would be illegal in that situation as much as any other, or that even if the requirement were supportable under the act in that situation, its broad applicability to other situations may make it legally defective. A court might arrive at the latter conclusion for reasons having ultimately to do with policies favoring prior limits on the exercise of discretionary power-the conservation of court resources, the symbolic maintenance of the rule of law, and the prevention of misoriented drift in the regulatory field caused either actively through the inaccessible administrative process we have noted or automatically through the responsiveness of planning to special uncertainties. In any event, the Court decides that the regulation may have to be rewritten and the agency position redefined before it can meet the cluster of applicable tests.

On the other hand, in Toilet Goods I the Court's decision announces that the regulation need not be rewritten before it can be adjudged legal in a particular case. Unless there is a high probability that the circumstances of a particular case will justify the adoption and announcement of the position, they would not have the determinative effect which would warrant a choice of enforcement proceedings as the mode of review. As we have pointed out, this is not simply an assumption, or tacit but authoritative interpretation, that the regulation has content only insofar as it is given meaning over time by the accretion of judicially approved applications. It is not, in other words, a judicial rewriting of the position itself. Therefore when the Court says that the unqualified position (that all manufacturers must give agency inspectors free access to all cosmetic formulae on pain of losing certification) cannot be overturned without regard, for instance, to whether ( 1 ) the formula sought to be inspected is that of a cosmetic whose safety is in doubt but not in such doubt that certification can legally be refused on that substantive ground, (2) there is no other way the agency can carry out its duty to protect the public from unsafe cosmetics at reasonable expense, and (3) formula secrecy is in fact maintained (to put what would seem to be the strongest case for enforcement), the Court 
should if rational have arrived at one or more of a number of conclusions.

One might be that if the agency position is supportable in that situation or some other, its broad applicability to other situations (where there is no doubt about safety, or where the doubt can be resolved at reasonable cost to the agency, or where the agency can protect the public from the danger it sees through a denial of listing or certification which would be legal under the standards given by the act, or where secrecy cannot be maintained) does not contravene the policies to which we have alluded above. That is, the existence of the position will not lead to coercion through increasing the costs of resistance by harassment, delay, and denial of unrelated benefits (including advice), or to blockage of judicial review, or to a waste of judicial resources on the post hoc definition of an acceptable rule in a long series of cases, or to a change in the regulatory field through shifts of technique and growth of new vested interests by virtue of reliance and contingency planning, or to accustoming agencies and the public to the appearance of unrestrained power.

Another such logically anterior conclusion might be that the situations in which the position is not justifiable are peripheral and unlikely. That would provide an alternative ground for concluding that consumption of agency time and energy in redefining the position would not be warranted, that the courts will not be saddled with the job of a burdensome case-by-case definition of boundaries, and that there is no appearance of unbridled power nor any great likelihood of jawboning. But such a determination that the justifying case is the usual case can be drawn only from facts laid before the court and after the resolution of subsidiary legal issues. To use our example above, the court must find that in most cases the safety of a cosmetic is in sufficient doubt to warrant inspection, that other evidence cannot satisfy such doubts, and that the legal standard governing listing and certification is such that despite the doubt a court will be constrained to reverse a denial of listing or certification on judicial review. ${ }^{295}$

The Court must in any event conclude that there are no fatal defects in the position as such, that, for instance, the use of de-certification as a sanction is appropriate because inspection promotes

295. The facts necessary to support such findings may be similar to those called for by the Court in Toilet Goods I-"what types of enforcement problems are encountered by the FDA, the need for various sorts of supervision to effectuate the goals of the Act." 387 U.S. at 163-64. Whatever may have been contemplated by the Court, the point here is that such facts are relevant to the decision to make the facts of a particular case relevant and thus to reject the declaratory action. 
efficiency in achieving the purpose of certification to protect the public from danger, or, to choose a more limiting legal standard, because in fact there are very few cases in which lack of safety cannot rationally be inferred from resistance to inspection, whatever the other evidence of safety offered by the manufacturer. Similarly, the absence of any guarantee of secrecy must be deemed not fatal, either because secrecy of cosmetic formulae is legally irrelevant, which is to say that there is no public interest in such secrecy, or because though relevant it is generally outweighed as a matter of law by problems of safety that are generally present, or because as a matter of fact secrecy can be and is maintained through record keeping by means of codes, or because "legitimate trade secrets" are adequately protected by actual enforcement of adequate laws or regulations and as a matter of law the protection of "legitimate trade secrets" is protection enough for the cosmetic industry. ${ }^{298}$

Whatever may be thought of the realistic possibility of conclusions such as these in Abbott and Toilet Goods $I$, they are implied if rationality is to be attributed to the Court's decision to terminate the declaratory action and make relevant the facts of the particular case. Courts subsequently handling the challenge-in the declaratory or the enforcement proceeding-must assume that one or another of these predicates has been established, if they assume rationality and seek to maintain the faultless logical network of judicial decisions that our jurisprudence requires. And they will do so. The implications of the Court's initial categorizing action mold attitudes and give starting points for analysis despite the fact that they are not spelled out and despite the fact that they may be seen as pairs or groups of alternatives. The various necessary determinations of fact and law exist even though they may not have been made: they are created when the Court's categorization is introduced into the logical machinery of the judicial process.

If it appeared that the Court were merely choosing to communicate in terms of art rather than ordinary language-to clothe sub-

296. See note 237 supra. FDA inspection authority under 21 U.S.C. \$ 374(a) (1964) docs not extend to cosmetic formulae. See Speech of Associate Commissioner Kirk at Conference on Evaluation of Safety of Cosmetics, Oct. 28, 1968; Brief for TGA at 18-21. There is thus some question whether the Act's criminal prohibition against the revelation by agency personnel of "information concerning any method or process which as a trade secret is entitled to protection" would apply. See 2I U.S.C. \& 331(j) (1964). In any event segments of the industry were doubtful that security could be kept whatever the sanctions and enforcement programs (see Drug Trade News, July 3, 1967, at $30, \mathrm{col} .3$ ) and agency representatives gave no assurance that trade secrets obtained through inspection under the Color Additives Amendments would not be revealed (see FDC Reports, Oct. 30, 1967, at 5). 
stantive determinations in a procedural terminology-there would be no particular cause for criticism. But the ripeness doctrine does not give us a mere manner of speaking. It gives us substantive determinations, clandestinely or inadvertently made. There is, to be sure, argument before the court on these matters. One cannot read the briefs without being aware that the parties are reaching for, or consciously finessing, the real questions. But there is no organized articulation, certainly none in the opinions. Legal issues are resolved, goals defined and values weighed, standards of review selected and applied, all without focused and explicit consideration of the facts and factors involved. This is precisely what all preliminary judicial procedure is meant to avoid at all costs-the premature determination of the merits. It is what the ripeness doctrine itself is meant to prevent, and what, ironically, it seems designed to foster.

Articulation of the process of categorization, one path to reform, would not be easy. There is some experience in developing an analytical framework in the separate but parallel activity of courts engaged in constitutional judicial review of statutes. ${ }^{297}$ But the analysis is not fully satisfying. It is never clear that the criteria for categorizing the rule, the legal standards, are anterior to the result. Both often seem to emerge at the same time. And the question remains: Is there truly any difference between sustaining the validity of the rule, qua rule, and determining that the vulnerability of a rule to constitutional challenge turns on the manner of its administration? Is there any necessity for the intellectual tension and complexity of purporting to postpone decision on the merits-other than the political necessity of preserving the judicial system by avoiding a confrontation without seeming to do so when a volatile constitutional issue is involved?2288 Most such decisions to let decision turn on the manner of administration can be viewed as the choice, for whatever appropriate and hopefully articulated reasons, of a narrow standard of review and its application to the challenged rule. The process of categorization can thus be resolved into the usual process of judicial review, and attention focused where it should be, on the formulation of the legal standard. It is often evident in constitutional litigation that the categorizing decision is meant to be a substantive decision of

297. See, e.g., Aptheker v. Secretary of State, 378 U.S. 500 (1964); United States v. National Dairy Prod. Corp., 372 U.S. 29 (1963); United Public Workers v. Mitchell, 330 U.S. 75 (1947). Cf. Younger v. Harris, 401 U.S. 37 (1971); Zwickler v. Koota, 389 U.S. 241 (1967); Dombrowski v. Pfister, 380 U.S. 479 (1965).

298. Cf. Zwickler v. Koota, 389 U.S. 241, 255-57 (1967) (Justice Harlan concurring); Village of Euclid v. Ambler Realty Co., 272 U.S. 365 (1926). 
great moment, and the de facto end to the process of review of the rule. Similarly, after Toilet Goods I one might argue that the Court had recognized "promotion of the efficient enforcement of the Act" as the governing legal standard provided by statute, ${ }^{290}$ and that although the Court did not purport to apply it because of the conventions of the ripeness doctrine, its breadth makes the final outcome a foregone conclusion.

In the administrative context we need not go so far as to try to resolve the process of rule categorization into a final decision on the merits. We need only submit that the process of categorization for the purpose of choosing whether to defer review is in practice superfluous. The ultimate conclusions necessary to categorize the rulethat the policies against breadth will not be violated, that the paradigm case is the justifying case-can rarely if ever be made, except in a case where the court could sustain the agency position against general challenge on the merits in the declaratory proceeding. Certainly in the absence of either such conclusions or judicial approval of the merits of the position as it stands, the position should be rewritten by the agency to narrow its scope and its threat, to devise and announce the necessary safeguards, and to spell out the factors relevant to its legal applicability. A declaration of illegality in a pre-enforcement proceeding is not after all the end of the matter, any more than reversal is in a special statutory review proceeding. It is a form of remand, leaving the agency to seek its goal within the limits and consonant with the goals recognized by the Court.

\section{B. The Problem of the Hypothetical Case}

We may suggest, therefore, that the only ground for deferring review to an enforcement proceeding without the kinds of substantive decisions we have outlined would be a finding that the issues are so intricate that briefs simply cannot bear the weight of elucidation, and that such concentration upon an illustrative example would be required that the declaratory proceeding would resemble a feigned or hypothetical case. There "jurisdiction" in the constitutional sense may be doubted, just as it may be doubted ${ }^{300}$

299. See text accompanying note 269 supra.

300. There is clear jurisdiction to settle a controversy over an issue, even without threat of near and irreparable injury. United States v. W.T. Grant Co., 345 U.S. 629, 632-33 (1953); United Public Workers v. Mitchell, 330 U.S. 75, 93 (1947); Aetna Life Ins. Co. v. Haworth, 300 U.S. 227, 241 (1937); Nashville C. \& St. L. Ry. v. Wallace, 288 U.S. 249, 264 (1933). The question whether a controversy is over an issue or whether it is over a hypothetical case would seem to turn on the kind of inquiry that is necessary to dispose of the merits of the legal challenge. The line is neces- 
when a party moots a case of enforcement review. Dismissal of the "case" would follow for reasons having to do with policies against making decisions in substantial reliance upon the facts of a fictional situation. A basic deference to the unfolding harmony of reality, and skepticism that imagination can adequately create its mysteries, are not out of place in administrative law.

Toilet Goods II might indeed be such a case. The Color Additive Amendments ${ }^{301}$ were passed in haste in the wake of a Supreme Court interpretation of the prior regulatory scheme that made it unwork$a^{3 b l e} e^{302}$ and after obscure and disorganized negotiations between representatives of the politically powerful cosmetics and beauticians groups and FDA officials over drafting; and they are baffling. They do not in terms give the agency licensing authority over finished products. Such a limitation was thought to protect important values. ${ }^{303}$ Licensing would lead to product standardization, when the public demanded innovation and variety; to official evaluation of "efficacy" and "truth," when the public valued illusion and the connection between illusion and reality was impossible to fathom; and to censorship of packaging and labeling, when the effect of censorship would be simply to break the spell they cast. ${ }^{304}$ Yet at the same time the amendments do give the agency licensing power over certain ingredients-but which ingredients was not easy to ascertain-and required that unsafe uses of such ingredients be prohibited: safety of some degree was also an important value announced and served by the legislation.

It was the agency's position that control over the safe use of a single ingredient involved control over the level at which it was used, the identity of other chemicals with which it was combined and

sarily drawn somewhat more sharply against "jurisdiction" in constitutional review. See Golden v. Zwickler, 394 U.S. 103, 108, 110 (1969).

301. Color Additive Amendments of 1960, 21 U.S.C. $\$ \$ 321-76$ (1964).

302. Flemming v. Florida Citrus Exch., 358 U.S. 153 (1958). For a short history of the legislation, see Toilet Goods Assn. v. Finch, 419 F.2d 21, 26-27 (2d Cir. 1969); Dyestuffs \& Chems., Inc. v. Flemming, 271 F.2d 281, 287-88 (8th Cir. 1959), cert. denied, 362 U.S. 911 (1960).

303. There should be no deprecating smile at the word "important." The images created by cosmetics and cosmetics advertising, for both the user and the used, are the stuff of life for millions; and the beliefs, hopes, and behavioral characteristics (such as confidence and daring) fostered by cosmetics may be quite as socially useful as those fostered by religion. $C f$. On and Off the Avenue: Feminine Fashion, THE NEw YORRER, Nov. 14, 1970, at 147-56.

304. See, e.g., Drug Trade News, Nov. 18, 1968, at 48; id., July 3, 1967, at 18, et seq.; FDC Reports, Jan. 23, 1967, at 11; 32 Fed. Reg. 12063, § 1.202(b)(2) (1967) (agency proposal for statement of "functional characterization of cosmetic" and its "intended cosmetic effect"). 
might react, the levels of those other chemicals, and the way in which the chemicals or their synergistic combination met the body (the part of the body affected, the length of the application, the frequency of the application, and so forth). It was the agency's further position that these controlled conditions of use were described by the formula for the finished product and its implied or explicit directions for use, and that the regulations at issue in Toilet Goods II therefore did no more than to spell out the implications of its authority. ${ }^{305}$

Faced with the possibility that Congress had adopted either inconsistent goals or a regulatory system inconsistent with its goals, a court might well want to trace through the workings of an actual ingredient in an actual product to understand the chemistry and medicine on which the equation of the part with the whole was founded, and the way in which the challenged regulations sought to reflect that science, before it turned to such questions as the frequency of synergism or the relationship generally found between the ultimate effect of the ingredient and the conditions of use over which control was being asserted-questions to which the facts of the particular case would give no answer.

In Toilet Goods II, however, the Court found it possible to proceed in the declaratory proceeding.

\section{Further Consequences of Jurisdictionad Litigation}

\section{A. Prejudging the Merits}

Tracing out the logic of what a court does in applying the ripeness doctrine is not the only way in which the merits can be shown to be affected during proceedings presumed to be preliminary. The merits often show through in a cruder, more obvious fashion in opinions written to explain the jurisdictional decision, and a pejorative term such as prejudgment becomes more descriptive of what happens in the course of jurisdictional litigation. The dissenting opinion of Justice Clark in Abbott is an extreme example. He would have terminated the declaratory action and denied review because

the regulations here merely require common honesty and fair dealing in the sale of drugs. The pharmaceutical companies, contrary to the public interest, have through their high sounding trademarks of long-established medicines deceitfully and exorbitantly extorted high prices therefor from the sick and the infirm. Indeed, I was so gouged myself just recently when I purchased some ordinary eyewash drops and later learned that I paid 10 times the price the drops

305. See, e.g., Brief for United States at 11-12; FDC Reports, Oct. 30, 1967, at 5. 
should have cost. Likewise, a year or so ago I purchased a brand name drug for the treatment of labyrinthitis at a cost of some $\$ 12$, which later I learned to buy by its established name for about $\$ 1.306$

No attempt whatever is made to marshal legal arguments and define legal standards. His is an unmediated response to what we have described as the true concerns or actual dispute of the parties. ${ }^{807}$

When one realizes, however, that Justice Clark views the majority opinion, purportedly allowing the declaratory action to proceed to the merits, as in practical effect terminating it in favor of the challengers, his response is at least understandable. ${ }^{308}$ Prejudgment appears whether the outcome of the preliminary proceeding is disapproval or approval of pre-enforcement review. ${ }^{300}$ We have already noted the probable effect upon future challenges of the Court's assertion in Toilet Goods $I$ that the governing legal standard is "efficient enforcement of the Act."310 Toilet Goods II illustrates the difficulties that the ripeness doctrine creates for the respondent when the jurisdictional point is mooted and he loses. The difficult problem of construing the Color Additive Amendments was outlined above: the amendments set up a regulatory system in which a good faith attempt to carry out one mandate on a scientifically sound basis must immediately conflict with other mandates, and the issue presented was not so much one of conflict between the agency and the statute as conflict within the statute itself. The agency could claim, and the Court agree, that it was not expanding the authority specifically granted, and the challengers could still argue that its exercise should be deemed illegal. But, in categorizing the legal

306. 387 U.S. at 201.

307. Justice Fortas' dissenting opinion differs only in that he reviews the legal materials at length. He too made his "jurisdictional" decision after he had decided that the generic-name-every-time regulation was "essential to the public interest" as a "cure for the possible danger and asserted deceit of peddling plain medicine under fancy trademarks and fancy prices which, rightly or wrongly, impelled the Congress to enact this legislation." 387 U.S. at 199. As we have pointed out, the function of trademarks in the legislated system and their intended relationship to marketing, quality, research, and price should be the central focus of the argument on the merits.

308. After losing the jurisdictional litigation in Abbott the FDA entered into a settlement with the trade association that had managed the litigation and negotiated new regulations that are now in effect. See 21 C.F.R: § 1.105 (1971).

309. Compare the prejudgment of the merits that occurs at the threshold stage of review of selective service actions, discussed in note 85 supra. For a particularly clear example of a judgment on the merits issued in the course of an opinion justifying a discretionary dismissal of a direct challenge to an agency position that its orders could be given retroactive effect, see Wilmington Chem. Corp. v. Celebrezze, 229 F. Supp. 168, 170-71 (N.D. Ill. 1964).

310. See pt. VII. B. 2. supra. 
issues for purposes of the ripeness doctrine, the Court flatly states that "the Commissioner amplified the statutory definition [of color additive] to include as color additives all diluents"; 311 volunteers that the "statutory exemption for hairdyes .... provides that hairdyes are totally exempt from coverage of the statute"; 312 declares that " $[t]$ he only question raised is what sort of items are "color additives" "; 313 and concludes that the regulations "purport to apply premarketing requirements to broad categories like finished products and noncoloring ingredients." 314 Faced with these indications of the Court's thinking, the agency might well choose to withdraw from the litigation and turn back to Congress. ${ }^{315}$

Evidence of prejudgment can dispose of a case as much through its effect upon the litigating calculations of the parties as through its precedential weight in future proceedings. Cases are abandoned upon reading the opinion denying an application for a stay pendente lite not solely or always because without the stay the ultimate remedy is worthless, but because the test for a stay requires a court to make an explicit prediction of success on the merits. ${ }^{316}$ The test for ripeness is not so explicit in this regard, but the question it requires a court to ask is in many respects the same as that presented by an application for a stay: Shall the court act now or later? And the obvious relevance 317 of the merits of the claim for relief to the question

311. 387 U.S. at 169 (emphasis added).

312. 387 U.S. at 169 (emphasis added).

313. 387 U.S. at 171.

314. 387 U.S. at 171 (emphasis added).

315. In fact the FDA did not withdraw. It returned to the district court to argue the merits and discovered that the "natural reading and understanding of the plain language" of the statute did not permit the agency to "enlarge" the definition of color additive to include finished products and noncoloring ingredients or to diminish the exemption of hair dyes from the statute. $278 \mathrm{~F}$. Supp. at 794 . The court referred the agency to Congress. Toilet Goods Assn. v. Gardner, 278 F. Supp. 786 (S.D.N.Y. 1968), affd. in part and revd. in part, 419 F.2d 21, 30 (2d Cir. 1969).

316. Jaffe \&. Vining, in L. JAFFE, supra note 20, at 694-97. Cf. the discussion in American Fedn. of Govt. Employees v. Paine, 436 F.2d 882, 889-90 (D.C. Cir. 1970), of the prejudgment of the merits that resulted from attempting to apply the "legal right" test for standing.

317. The relevance of the merits could cut different ways in constitutional and administrative judicial review. The likelihood of success of a constitutional challenge might be a ground for deferring review and thus promoting a policy of avoiding constitutional confrontation. Cf. text accompanying notes $297-99$ supra. If administrative review operates on the opposite presumption, that questions should be resolved rather than avoided, likelihood of success on the merits should favor immediate relief.

The difference would reflect a belief that the resolution of a question in administrative review sets the stage for legislative review whereas judicial approval of a constitutional challenge forecloses the legislative process. Neither, of course, is entirely true. The legislature is often incapable of responding to a judicially induced expansion or contraction of a regulatory scheme, except within a framework of values 
whether the claimant should be sent away empty-handed makes the line between granting review and granting relief a difficult one to maintain, and necessarily gives to opinions written at the jurisdictional stage a predictive and dispositive effect. ${ }^{318}$ That predictive effect becomes even more pronounced in a case dismissed for want of ripeness alone, when it is remembered that the court has presumably satisfied itself that the challenged position is "final" and guiding the activities of the institution. A litigant who is asked to produce a specific factual context may naturally ask, if a position that was ostensibly adopted on general considerations cannot be understood in light of general considerations, why should it not be withdrawn and reasserted only insofar as the circumstances of a particular case demand? ${ }^{319}$ The answer which will occur to him is that the position can be and has been understood as a general matter, that as such it has been authoritatively approved, and that all that remains for later litigation is an exploration of its edges.

One might respond that when litigants desist after reading between the lines of opinions issued at preliminary stages, little is lost besides the spectacle of playing out the game. The ultimate outcome would not be different, at least not in a sufficient number of cases to outweigh the judicial resources saved by early terminations. But however appropriate such considerations of economy may be in ordinary civil litigation, they are quite inappropriate in the administrative context. There is more at stake in avoiding the effects of prejudgment than harm to the integrity of the judicial process and public respect for it. The manner in which the issues are formulated-and left-in an administrative review proceeding is as important as the outcome, who wins or loses. At times the formulation of

defined by the court itself. An eloquent and authoritative judicial opinion of what the governing law is may often be accepted, even by legislators, as a statement of what the law should be, especially where the basic values served by many organic delegating statutes are involved. The political impact of the judicial opinion in the administrative process is undeniable; it goes further than shifting the burden of inertia in the legislature. But there are also any number of ways in which the legislature-and history-can nullify nullification.

318. It is true that the jurisdictional decision and the decision on the merits may merge when the issues are found sufficiently ripe (e.g., Textile \& Apparel Group, American Importers Assn. v. FTC, 410 F.2d 1052 (D.C. Cir.), cert. denied, 396 U.S. 910 (1969); Lynd v. Rusk, 389 F.2d 940 (D.C. Cir. 1967); In re Amoury, 307 F. Supp. 213 (S.D.N.Y. 1969); Stephens v. Smith, 294 F. Supp. 31 (E.D. Va. 1968); Western Addition Community Org. v. Weaver, 294 F. Supp. 433 (N.D. Cal. 1968)), and the court treats the merits and the jurisdictional problem in the same opinion. But the merits will still be prejudiced during briefing and argument in a two-step procedure. The absence of separate opinions simply makes the prejudice difficult to trace.

319. Cf. A.L. Mechling Barge Lines, Inc. v. United States, 368 U.S. 324 (1961) (agency withdrawal of position during review). 
the issues-the separation of strands of policy, the creation of history, the articulation of inchoate values, the illumination of how the system as designed actually works, and the orderly cataloging of various effects-is the outcome in all practical effect, since an honest analysis will leave neither side satisfied and both will inevitably turn to Congress to seek a solution of the problem. In the Toilet Goods cases, a judicial resolution of the issues presented might after full consideration be deemed impossible, and the proper and most useful function of a court would be the preparation of a "remand to the legislature." 320

The administrative process includes a legislative element, a more or less continuous feedback and redesign of the system being used to realize public values and a redefinition of the values being pursued. Neither system nor goal is static. There is therefore no reason for a court to assume in an administrative case that values are conflicting and that the judicial function is to choose rationally between competing values, as it must so often do in other litigation. The values represented by the various parties and recognized by Congress may be quite compatible, but not attainable through the given regulatory system. An important part of the judicial function, and one for which the judicial process is well fitted, is to perceive where such a situation exists, and to aid the legislature-or, if one prefers, the agency, the regulated parties, and the beneficiaries in the regulated field-by defining the sources of difficulty and the choices involved..$^{321}$ In the Toilet Goods cases, the Court failed in this function. After the litigation the issues will go to Congress no less confused than before; and the failure may be traced to a doctrine that breaks the ordinary evolution of issues in the course of litigation, raises strong temptation to prejudgment, and contains serious potential for premature termination of the judicial role in the ongoing administrative process. ${ }^{822}$

320. The term is Professor Sax's. Cf. J. SAx, Defrending the Environment 175 (1970); Sax, The Public Trust Doctrine in National Resource Law: Effective Judicial Intervention, 68 MICH. L. REv. 473, 49I-502 (1970). The remarks on the generic-name provision at issue in $A b b o t t$ by Senator Kefauver, its sponsor, are prescient: "Those in the future who attempt to study the legislative history of this measure as it passed through its various stages may be forgiven if they become somewhat confused." 108 CONG. REC. 22037 (1962).

821. Compare the review provided Wisconsin, California, New York, and Phillips Petroleum of the FPC's change from individual to area rate proceedings in Wisconsin v. FPC, 373 U.S. 294, 307-14 (1963).

322. Compare Textile \& Apparel Group, American Importers Assn. v. FTC, 410 F.2d 1052 (D.C. Cir.), cert. denied, 396 U.S. 910 (1969). Although, in addressing ripeness and the need for review of the ex parte licensing rule promulgated by the agency, the court mentioned that the challenge "would, if successful, require permanently en- 
The objection may be raised that basic to the judicial responsibility is dispute solving, indeed that such a role is a constitutionally settled one. A court must, to solve disputes, assume that the rules of the game are fixed, not in flux, and must isolate itself from the process of change in the legal standards it is called upon to apply. Such would be a very narrow view of the meaning of the constitutional term "controversy," and of what courts do within a system of law created in large part through judicial process. But the short answer here is that even if courts should not cast an eye toward the legislative process in making substantive determinations-for reasons drawn from their necessary role or out of concern to maintain a visible insulation from politics-they must be sophisticated enough to view the administrative process as a whole, and the effect of their activities upon it, in devising their procedures. The fact that the ripeness doctrine may make judicial review less useful to the legislative part of the administrative process is surely relevant to a consideration of its merits.

\section{B. Interference in the Legislative Process}

The ripeness doctrine impairs the legislative part of the administrative process in another way, unrelated to the formulation of issues. The agency may take a variety of related positions in a number of ways. Often, as in the Toilet Goods cases, the positions appear in a

joining the rule" on the merits the court matched its remedial action to the precise problem before it, and did not resolve the issues in any final way. $410 \mathrm{~F} .2 \mathrm{~d}$ at $1055,1058$. It did order the administrative position withdrawn, and to that extent revealed and acted upon its own evaluation of the ultimate impact of the position on congressional policy as well as its presumption against unnecessarily expanding the dark side of the administrative process. But otherwise it sought to prepare something of a legislative remand. The Commission had, for instance, relied upon authority granted by statute to the Customs Bureau to detain imported goods, and upon the fact that Customs had set up a licensing procedure for imported woolens similar to that established by the Commission. It was argued that consequences inconsistent with the goals of Congress could not, therefore, be held to flow from the Commission position. The court did not utterly reject the argument, but noted that Customs was not a party in the proceeding before it, nor indeed in the administrative proceedings leading to the Commission position, so that the extent to which Customs enforced its position or desired enforcement by Commission personnel was unknown, and that in any event Congress might choose to achieve its desired balance of values in the regulatory field as much by its choice of enforcing agencies as by its articulation of substantive standards. In the end, then, the court transferred the "case" to other fora where the problems that had led the agency to adopt its position, and the petitioners to mount their challenge, might be more fully aired and resolved. This is indeed what courts purport to do when they deny jurisdiction for want of ripeness, and do for the same purpose, to forestall premature judgment on an inadequate record and argument even though the parties may have standing and the agency action may be final. But here the issues that are transferred have been ordered and elucidated after open argument, an achievement not possible without getting to the merits. 
number of different regulations and the affected parties may bring the regulations together in a single challenge. At the same time they may be engaged in a process of multiparty negotiation, either through the medium of Congress or in preparation for a joint approach, looking to a revision of the regulatory system that will encompass some or all of the positions challenged on judicial review.

Prior to the decisions in the Toilet Goods cases, the cosmetics industry and the Food and Drug Administration had been working for some time on a bill that would place the manufacture of cosmetics under comprehensive regulation but that, departing from previous legislative efforts, would not be modeled on the drug provisions of the Food and Drug Act. ${ }^{323}$ Instead of individual approvals of each new product in a quasi-judicial procedure, the system would rely on a computerized and continuous flow of information about the uses of chemicals in cosmetics, so designed that safety problems could be monitored and corrected without standardization, label review, or development of notions of cosmetic "efficacy." 324 In light of the extraordinary number of cosmetic companies and products and their short market life, the system had much to recommend it to an agency concerned about priorities in the budgeting of time, attention, and regulatory personnel, even though it restricted the agency's ultimate discretionary power, and much to recommend it to a Congress concerned not only about the various values we have mentioned, but also about the effect of comprehensive federal regulation upon the competitive structure of an industry consisting in large part of numerous small companies operating on a short lead time. ${ }^{325}$ The proposal provided some camouflage for formulae, but during the negotiations the industry was using its consent to enforcement through inspection as a bargaining counter, chiefly in return for the agency's agreement to abandon an initial demand for finished product licensing. ${ }^{326}$

Under the ripeness doctrine, however, each regulation, or "case" created around each challenged position, is analyzed independently. What happened in the Toilet Goods review proceeding was that the issue of inspection rights under present law was split from the issue of premarketing finished product licensing and deferred. The in-

323. See Drug Trade News, July 3, 1967, at 18, et seq.

324. See Speech of Commissioner of FDA, April 23, 1968, in FDC Reports, April 29, 1968 , at 33.

325. Cf. Drug Trade News, July 3, 1967, at 47, col. 2; FDC Reports, March 20, 1967, at $3-4$.

326. See Drug Trade News, July 3, 1967, at 18, col. I; Food Chemical News, Jan. 15, 1968, at 30 . 
dustry was deprived of its bargaining counter, ${ }^{827}$ and the likelihood of agreement upon a legislative scheme that would have resolved many of the problems facing the Court was correspondingly diminished. This is a cost that should be taken into account in determining the impact of a denial of pre-enforcement review upon the parties and upon the regulatory system itself-a cost measured by the degree of interference in the strategic calculations of affected persons working on the same problems outside the judicial process and the consequent distortion (if that interference is not rationally justified in advance by other articulated considerations) of the outcome of the legislative process. ${ }^{328}$

\section{Uncertainty}

There is finally the cost of uncertainty. The exercise of discretion, judicial or otherwise, is never predictable, but leaping the hurdle of ripeness seems particularly a matter of chance. There is little guide for a challenger in the cases, to what makes perfectly crystallized and final administrative positions "appropriate" for pre-enforcement review, or to what kind and degree of "harm" to himself is sufficient. What sort of hardship should he argue? The costs of compliance if he should later turn out to be right? But these are contrived, because they cannot be incurred without eliminating the need for enforcement and the opportunity to learn that he is right. And the greater they are (the safety testing costs in Toilet Goods I were thought to be crushing) the less likely it is that they will be incurred before enforcement review. The penalties and losses he will suffer if he is defiant and turns out to be wrong? But these may not receive sympathetic attention, because if they are incurred they are deserved. The cost of protecting himself from both the agency and his competitors (for instance, by accumulating extra stocks of diluents in Toilet Goods II) while waiting for someone else to settle the issue? But a court cannot weigh these without admitting that it may deny all review to the challenger before it. And what of other costs, such as, in Toilet Goods II, the complex litigation over venue that will be necessary before enforcement review in a certifica-

327. The substantive legal effect of a decision to defer may be viewed as more definite than the effect of a decision to continue with a declaratory proceeding. In any event, the agency was reaching in seeking finished product licensing without congressional approval, whereas the industry was put in jeopardy of losing what it had long thought secure.

328. The fact that the Court did not view the issues in Toilet Goods I as ancillary to the issues in Toilet Goods $I I$, over which jurisdiction was retained, illustrates again the presumption against judicial review embodied in the ripeness doctrine. Compare Toilet Goods Assn. v. Celebrezze, 235 F. Supp. 648, 652 (S.D.N.X. 1964). 
tion proceeding is possible, which the Court notes but gives no weight? $^{320}$ Then there is the question of degree. It would be very difficult to say without hindsight that the cost of compliance in Abbott (printing new labels), which was found sufficient, was greater than the cost of compliance in Toilet Goods II (allowing inspection), which was found insufficient.

The result is a heavy clog on review. A resisting agency may count on, and a challenger must take into account, a lengthy and costly period of preliminary litigation before the merits can be reached, even in a declaratory action. ${ }^{330}$ As in obscenity cases, there is no reason not to think that the next court will have a different view of ripeness. By the same token, the doctrine has no prophylactic effect. Direct challenge will be tried, and if it is rebuffed the courts have burdened themselves with two or more cases on the same subject, the direct suit and the subsequent challenge or challenges in enforcement actions ${ }^{331}$-unless, of course, subsequent challenge is deterred by cost, jawboning, prejudgment, or irreversible changes in the regulatory system. There is no judicial economy, only parity bought at an unacceptable price.

\section{Judicial Review Without the Doctrine of Rupeness}

There are, of course, real problems raised by expanding claims to direct judicial review of agency action, and it may be feared that abandonment of the doctrine of ripeness either by judicial renunciation or statutory codification will leave the courts without means of response. But other tools at hand would seem adequate to the task. We have noted the degree to which the various jurisdictional prerequisites written into the APA overlap in their function and effect. ${ }^{832}$ The problems of direct review to which courts may have responded under the rubric of "ripeness" can be handled and, in-

329. 387 U.S. at 158 n.3. Although it is not clear that General Motors Corp. v. Volpe, 321 F. Supp. 1112 (D. Del. 1970), is a case in which a question of ripeness was presented (see National Automatic Laundry \& Cleaning Council v. Schultz, 443 F.2d 689 (D.C. Cir. 1971)), the district court purported to weigh the hardship to the challenger in declining to accept jurisdiction in light of the examples provided in Abbott and the Toilet Goods cases. Review in enforcement proceedings entailed a risk, inter alia, of a $\$ 400,000$ penalty. The court did nothing to encourage hope that the hardship test can be made to work in a predictable way when it concluded "what is to most men and to the Court a staggering sum is not nearly as significant to GM or, for that matter, to other American automobile manufacturers." 321 F. Supp. at 1128-29.

390. See the summing up of the Toilet Goods litigation in Toilet Goods Assn., Inc. v. Finch, 419 F.2d 21, 23 (2d Cir. 1969).

331. This assumes that the issue on the merits is worth litigating. If it is frivolous it can be disposed of as such.

332. See generally pt. III. supra. 
deed, are now handled in a more straightforward and effective way through the careful application of doctrines whose terms and premises are not at war with the modern role of courts in the administrative process.

If the concern is interference with the initiation of important regulatory programs, it may be noted that an assumption of jurisdiction does not stop administrative action, and the law of stays reflects a presumption in favor of the agency on the merits. ${ }^{333}$ Unless a court means to defeat review or prejudge the merits, postponement of review should not give an agency greater confidence or capacity to proceed on challenged assumptions. The degree to which a court actually intrudes after consideration of the merits is governed by the definition of the precise issues for decision, the scope of review, and the kind of remedy fashioned. All are matters of judgment for the court.

If the concern is the possibility of drying up the useful flow of advisory opinions from agencies to interested persons, ${ }^{334}$ it may be noted that an advisory opinion is by definition one that does not represent a crystallized agency position meant to guide agency personnel and others in all relevant contexts. As such it may be protected from review either by the doctrine of finality or by the unreviewability of truly discretionary actions. But, if in fact an agency position should emerge in one or a series of announcements labeled "advisory," then the hope of preserving the planning advantages that are afforded by the practice of issuing advisory opinions cannot justify withholding review of that position. ${ }^{335}$ There may be greater disadvantages to planning, and certainly to planning of a properly oriented kind, in leaving the position in effect. It is not after all the relative desirability of planning per se that should move a court, but rather the relative desirability of the results

333. See Jaffe \& Vining, in L. JAFFE, supra note 20 , at 687 . The presumption in its favor with which an agency enters a review proceeding operates on the merits and in determining the scope of review or the recognition of expertise. It cannot be a reason for denying review, else it conflicts with the presumption in favor of judicial review and the controlling considerations that underlie it.

334. See Helco Prods. Co. v. McNutt, 137 F.2d 681, 684 (D.C. Cir.), cert. denied, 320 U.S. 761 (1943).

335. See, e.g., Gordon \& Co. v. Board of Governors of Fed. Reserve Sys., 317 F. Supp. 1045 (D. Mass. 1970) (direct review of published response to a stated set of hypothetical facts). The situation is akin to the review of "discretion." A desire to preserve the flexibility afforded by a grant of discretion cannot be a reason for refusing to review a fixed rule on which an agency has come to rely to avoid the necessity of weighing all the relevant factors in a particular case. See Oestereich v. Selective Serv. Sys. Local Bd. No. 11, 393 U.S. 233, 237 (1968). 
of planning for the achievement of regulatory goals. Stability or smoothness of commerce may be one, but only one of those goals.

This becomes particularly evident when the party seeking direct review is not the party that sought the opinion but rather a beneficiary of the regulatory system (which might or might not be also subject to direct regulation by the agency) claiming that the agency's action in issuing a favorable ruling may irreparably injure legislated values. Certainly if private action in reliance upon an "advisory" opinion is protected by agency practice or otherwise," the position taken by the agency is made "final" for adversely affected parties when private activity goes forward, and in any event the position should be reviewable insofar as agency inaction or refusal to act is subject to review. In such cases courts may protect the practice of advisory opinions to the extent that such protection is justifiable by observing the limitations upon review still imposed by the tests for standing. Courts may also require challengers to exhaust administrative remedies, which would permit agencies to separate their processes for the regular issuance of opinions to petitioning parties from their processes for considering the significant and less frequent issues raised by third parties. ${ }^{337}$ There are further protections available when the opinion is unfavorable to the party seeking it and that party or one similarly situated seeks review. For whether a position has crystallized and just what has crystallized are again matters subject to the judgment of the court, and it may properly give an agency a greater benefit of the doubt ${ }^{338}$ when the commu-

336. See $1 \mathrm{~K}$. DAvis, supra note 50, \& 4.09, at 265-67; Willapoint Oysters, Inc. v. Ewing, 174 F.2d 676, 682 (9th Cir.), cert. denied, 398 U.S. 860 (1949) (FDA "advisory announcements"); I6 C.F.R. \& 3.61(d), (e) (1971) (action taken upon FTC advice on coverage of order immune from sanction until advice revoked); Section 23(a) of the Securities \& Exchange Act of 1984, 15 U.S.C. § 78(a) (1964) (good faith reliance on rules issued "as necessary for the execution of [Agency] functions" makes party immune from liability regardless of invalidity of rule); Sections 9-10 of the Portal-to-Portal Act, 29 U.S.C. \$\$ 259-60 (1964) (good faith reliance on administrative interpretation a defense against wage recoveries and penalties under the Fair Labor Standards Act).

337. Cf. the discussion of APA \& 5(d) in pt. III. B. supra.

338. If an agency does not deny that there is a crystallized position but resists review there is no problem. The issuance of advisory opinions will be clearly seen to be covert rule-making. The problem arises when the agency denies in court that there is a final position, but the pattern of its advice addressed to those in the field suggests otherwise. When advisory opinions relating to particular fact situations are in issue, as opposed to, for instance, press releases and other forms of communications, a court may wish to assume and permit a lower standard of care and responsibility in the choice of words and accept, therefore, a higher risk that planning in the field will be misdirected, simply to promote agency willingness to give advice. To the extent that an agency must hone its opinions to avoid appearing to say what it does not mean, the cost of each opinion in agency resources is raised and their availability necessarily limited. Judge Leventhal suggests that the institutional status of a position might be dissolved by "an affidavit by the agency head-not a mere argument 
nications are advisory opinions, ${ }^{339}$ in view of the systemic effects that a reduction in advice and consequent increase in uncertainty might produce.

If the concern is the possibility of abuse of rights of direct review to impede the prosecution of a particular case, the requirements that issues presented on direct review be distinctively legal in character, and that the challenged positions be the end result of a process of considered agency formulation, should be sufficient protection. Interested third parties who are sophisticated enough to watch a particular case for evidence of generally applicable agency positions are sophisticated enough to know that positions often change in the course of litigation. Legal positions apparently taken in a particular case at a given point in its progress are also difficult to disentangle from factual issues, which makes them at once unsuitable for direct review and likely to change as the factual premises of the case fall into place. The judicial evaluation of the situation can be expressed through the doctrine of finality, ${ }^{840}$ and courts that are sensitive to that doctrine's function of separating those positions that persons active in the regulatory field take into account from those that they do not will be able to draw the necessary lines. When a position emerges that can be viewed as "final" in this respect, and when the petitioner seeking direct review is the object or a proper party to an administrative adjudication, the court has the additional flexibility provided by its authority to decide whether to break a question out of an already created caseto view the agency position, in the words of section 10, as "a preliminary, procedural [or] intermediate action not directly reviewable." ${ }^{341}$ When the petitioner is the object of a prosecution

by its court counsel-that a matter is still under meaningful refinement and development" which "outlines the method of seeking reconsideration." National Automatic Laundry \& Cleaning Council v. Schultz, 443 F.2d 689, 701, 708 (D.C. Cir. 1971).

339. We say "greater" rather than full benefit of the doubt. It is not self-evident that stability and predictability in a regulated field increase with every increase in the availability of advisory opinions. Encouraging the practice may deter agencies from detailed rule-making that might provide more guidance and confidence.

340. See, e.g., Lever Bros. Co. v. FTC, 325 F. Supp. 371,373 (D. Maine 1971). When the prosecution is initiated within the agency and the petitioner is the object of the prosecution, the doctrine of exhaustion is available for the same purpose. $C f$. Henson v. United States, 321 F. Supp. 122, 127 (E.D. La. 1970).

341. Cf. Ewing v. Mytinger \& Casselberry, Inc., 339 U.S. 594 (1950) (review of probable cause determination in multiple seizure action denied); Landis v. North America Co., 299 U.S. 248 (1936) (stay of direct review proceedings pending completion of enforcement review proceedings reversed in part); Columbia Broadcasting Sys., Inc. v. United States, 316 U.S. 407, 421 (1942) (possible exclusivity of enforcement review for positions announced in enforcement proceedings); Pharmaceutical Mfrs. Assn. v. Gardner, 381 F.2d 271 (D.C. Cir. 1967) (review of preliminary question in adjudicatory rule- 
initiated in a sister court, a court has all the discretionary powers to transfer venue, stay its hand, or fashion appropriate relief that the Court in Abbott cited in support of the presumption in favor of pre-enforcement review..$^{842} \mathrm{Such}$ authority to protect the integrity of existing organizations of issues and parties-where timing, strategy, factual inquiries, and substantive positions are mutually interdependent and rest upon a construct of prior assumptions, bargains, and contested outcomes-is necessary so long as matters continue to be handled through legal process and seems essentially unlimited in its scope.

If the concern is the possible litigation of hypothetical cases once the resolution of issues outside actual factual contexts is permitted, there are a number of protective devices other than the ripeness doctrine. Constitutional jurisdiction may be lacking when the resolution of the challenge requires the litigation of a feigned case, ${ }^{843}$ and that may be expressed through the doctrine of standing. Similarly, the adversariness required for standing, the "controversy," may be absent when the complaint is about a truly hypothetical state of affairs. Otherwise whether the impact of the challenged position on the regulatory field is hypothetical or not really goes to the merits. If after examination of the regulatory values the court finds that the position has no effect adverse to those values on the planning and activities of those in the field, it sustains the agency position. Whether the proceeding has been an unnecessary consumption of judicial resources because the dangers are in fact remote cannot, again, be determined without judging the merits. But it may be noted that the costs to a party of mounting a challenge, including perhaps the cost of prejudicing a number of other administrative or legislative interests, are such that the complaint is not likely to be entirely hypothetical. In these circumstances an agency argument that the fact situation where the position may have an adverse effect will never arise, or that the position was not meant to extend to that

making denied); Algonquin Gas Transmission Co. v. FPC, 201 F.2d 334 (Ist Cir. 1953) (review of denial of temporary permit granted); Crick, The Final Judgment as a Basis for Appeal, 41 YaLe L.J. 539, 545 (1982). In Abbott the Court viewed the significance of the position challenged in Ewing as exhausted within the confines of the "case." It was of interest only to the respondent, and concerned with specific factual questions. Had more general issues been raised by what the agency did in Ewing-such as what kinds of behavior or evidence would in the future result in exposure to the sanction of multiple seizures-the general interests in reviewability would arguably outweigh whatever interests there may be in preserving the integrity of the "case" as the organizing vehicle for judicial review.

342. 387 U.S. at 154-55. See pt. VI. B. supra.

343. See pt. VIII. B. supra. 
situation and so cannot affect it, is an admission that the position is or should be withdrawn pro tanto. ${ }^{344}$ If the use of judicial resources to resolve the issues raised is truly unnecessary, then so is maintenance of the position in a form that produces challenge; and on an agency's refusal to reformulate a court may proceed on the assumption that the case is not hypothetical.

\section{ConcLusion}

Denial of access to the courts except for the vindication of what could be recognized as a private or property right may well be associated with the absolute value of freedom in laissez-faire liberalism. ${ }^{345}$ As that ethical system has become untenable with increasing recognition of the nature and needs of modern social organization, in which the happiness of man must be achieved more through the pursuit of legislated goals than the lifting of general restraints on individual choice, the ultimate justification of doctrines of standing and finality more restrictive than necessary to ensure true litigation may have disappeared also. It may thus have been inevitable that the Court should move in the direction it has, replacing "legal interest" or "invasion of a property or quasi-property right" with a formula that reflects a quite different justification for the exercise of judicial power. Barlow v. Collins, ${ }^{346}$ in which economically dependent citizens came to the courts to restrict their legal freedom in order to gain their liberty, and were first denied and then given access, was a particularly appropriate vehicle for the doctrinal shift that occurred. The case posed so sharply that central dilemma in liberal philosophy, the incompatibility of freedom from government and freedom from one's fellow man.

In light of this development, one may have some confidence that the jurisdictional doctrine of ripeness as presently formulated will be replaced. It is no longer true that a case should be in such a posture that a court will have the last word and only the last word. It is no longer true that if "jurisdiction" is accepted a court will face a choice between two fixed points, one established by the agency on behalf of Congress and the "public interest," and the other established by the judiciary acting on behalf of and protecting "private" interests. ${ }^{347}$ If that were the choice on the merits we would

344. See Giumarra Vineyards Corp. v. Farrell, 431 F.2d 923, 925 (9th Cir. 1970).

345. Cf. the illuminating discussion of laissez-faire and law, Ethics and Economic Reform, in F. KNIGHT, FREFDOM AND REFORM 45, 64-65, $69-71$ (1947).

346. 397 U.S. 159 (1970).

347. Cf. the dissenting opinion of Justice Fortas in Abbott Laboratories v. Gardner, 
not have a presumption in favor of judicial review. A court does not assume responsibility to make any ultimate choice when it undertakes to carry out the function of judicial review. After moving as far as rational argument can go, the court may choose to let certainties emerge from the further operations of a reoriented system if it does not sustain the administration position as such. But if the court should, after review is complete, choose to resolve issues against the agency and replace the agency position with rules of a different character, it will not be acting as agent of the private challenger, but on its own responsibility as an integral participant in the administrative process.

A belief that the ultimate justification for maintaining the doctrine of ripeness has disappeared is strengthened when one considers the reasons that can be advanced in support of a presumption against postponing review to enforcement proceedings. The courts do not conserve their resources by postponement, because the issue is likely to return and, if there is much delay, produce a number of appeals in a variety of procedural or substantive contexts that would otherwise not burden the courts. Others than the plaintiff are in fact interested in resolution of the issues. The systemic effects of delay and uncertainty may be important and irreversible. Relegation to review through enforcement proceedings may well subject individual parties to jawboning, whereas pre-enforcement review can be undertaken on a group basis and vigorous challenge will not be deterred. The development of judicially managed class actions, trade association litigation of selected problems, and other forms of industrywide participation in review proceedings, gives to judicial decisions a more binding effect and thus does conserve judicial resources, as does the possibility of staying or merging disparate actions raising the same issue. The same widespread and orderly participation in review maximizes aid to the court in reaching a carefully reasoned disposition. An agency may be able to escape review of a position in an enforcement proceeding by advancing overlapping or discretionary grounds for the specific outcome on which the court necessarily focuses in such a proceeding. In an enforcement proceeding the issue necessarily receives attention-from party, agency, and court-in proportion to its importance to the case,

387 U.S. at 178. "[A] suit for injunctive or declarative relief will not lie absent a clear demonstration that the type of review available under the statute would not be "adequate,' that the controversies are otherwise 'ripe' for judicial decision, and that no public interest exists which offsets the private values which the litigation seeks to vindicate." (Emphasis added.) 
rather than its importance to the functioning of the regulatory system as a whole, a defect that can cut against those defending the position (which may include parties in addition to the agency) or those challenging it, depending upon whether the factual context is appealing or unappealing. Jurisdictional litigation is costly, uncertain, and itself a charge on judicial review. And in the course of passing upon jurisdiction, the merits are often in fact adverted to-and, therefore, in all but very important cases, disposed of for all practical purposes-with adverse effect upon the intellectual integrity of the review and indeed the judicial process itself.

Taken together, these considerations suggest more than a presumption. They suggest the elimination of judicial discretion to avoid explicit treatment of the merits of a challenge once the challengers have established their standing to litigate, the finality of the position challenged, and the absence of preclusion. It is of course possible to conceive of terms in which the ripeness doctrine might be recast to maintain such discretion in light of the public function of judicial review. Courts could inquire into the relative seriousness of the interim effects of a position upon the regulated system if immediate and direct review is denied and the position should ultimately be found illegal. Courts could also seek to articulate the conclusions of law which must underlie a determination that a set of particular facts is relevant to the legality of an agency position. But we have noted the complexities, the dangers of prejudgment and poor judgment, and the waste that would ensue from such recasting. It is preferable that the doctrine be abandoned, and that attention be focused instead upon the expansion of judicial sensitivity to the actual social and economic impact of institutional decisions. 